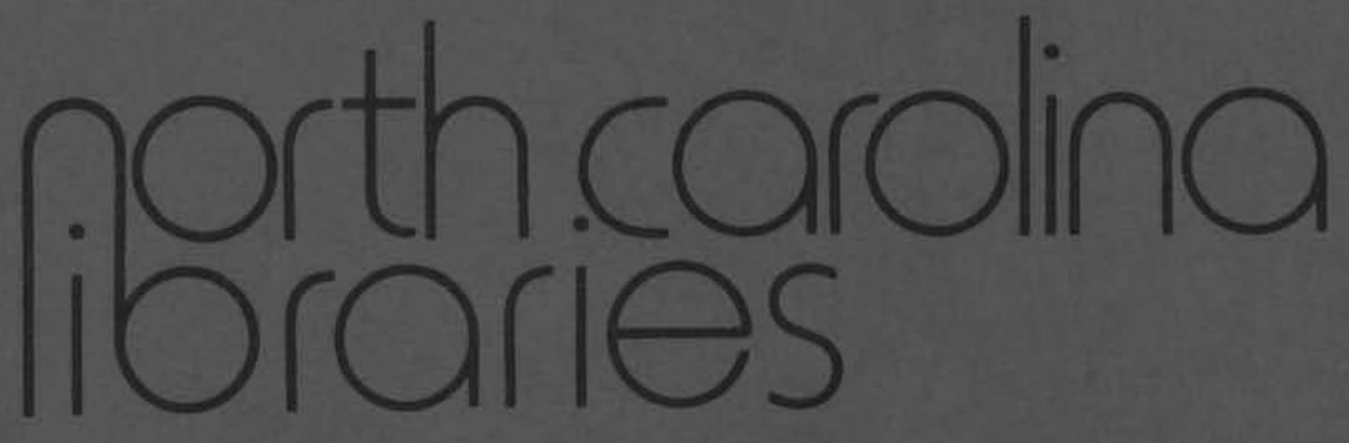

Mention the ferm network to a group of librarians and you will probably get as many different answers as there are people present.

John Welch, 1984

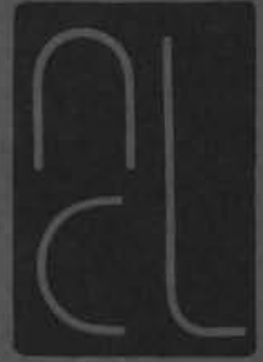




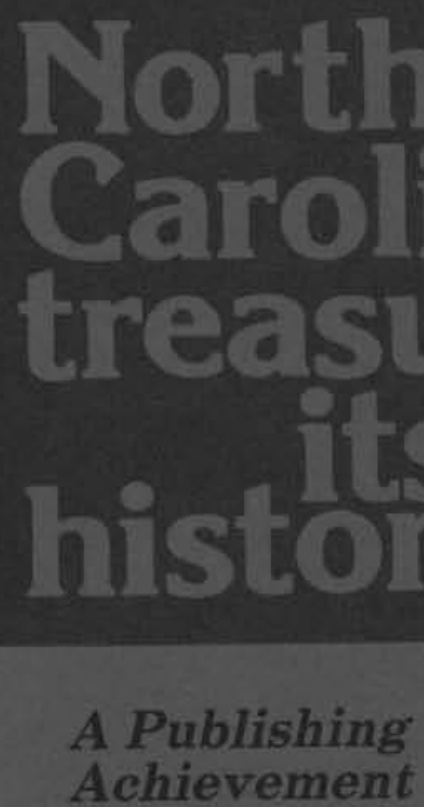

A goldmine of North Carolina history awaits you in the Heritage Book Collection.

Each $9^{\prime \prime} \times 12^{\prime \prime}$ volume is printed on archivatgrade paper, is hardtoound and embossed with its counfy seal.

กร

Tres

S

The indexed, 500 plus page volumes are highlighted with wonderful old photographs of the county and its people.

Books are now available about

counties marked in gray on

the map below.

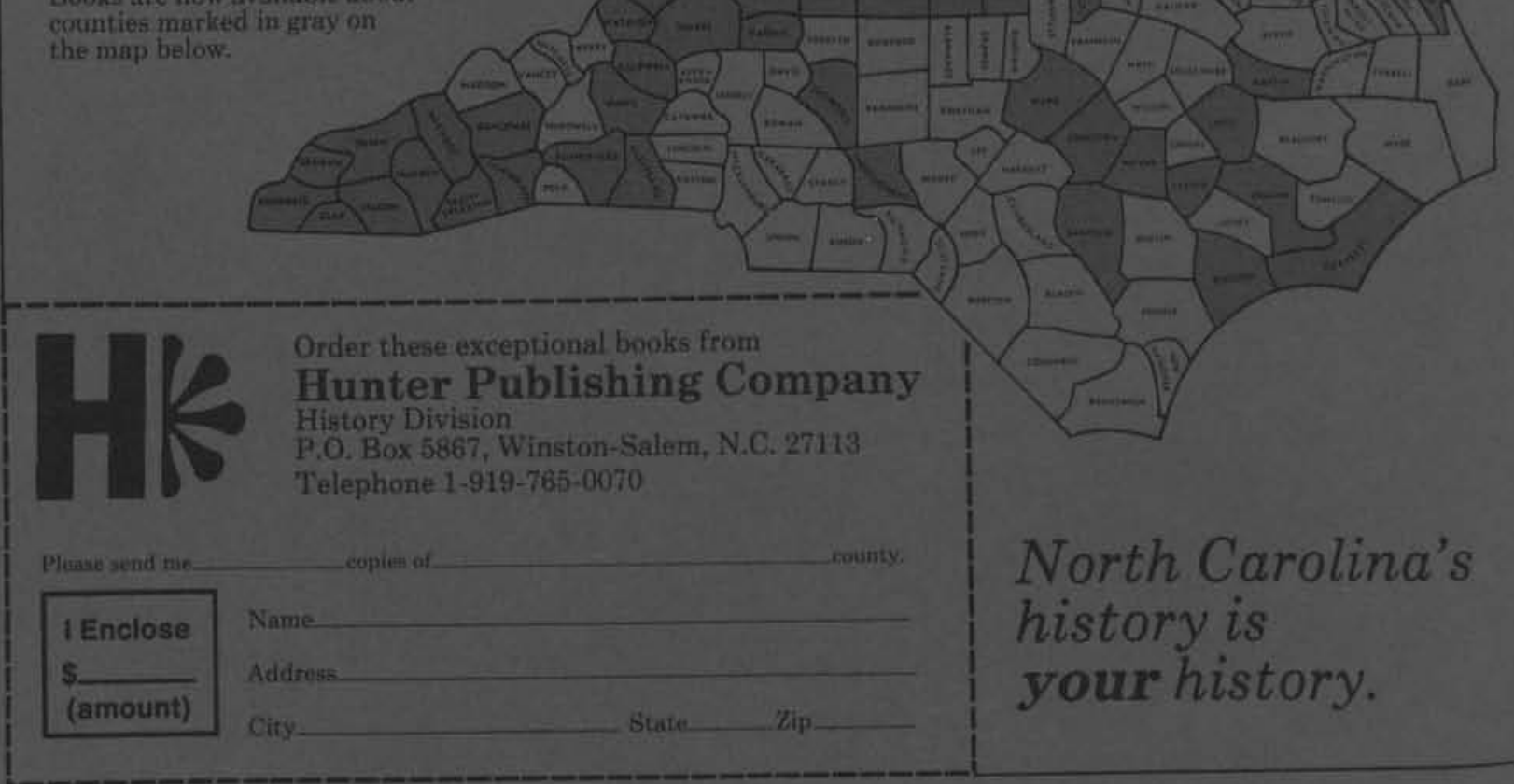

Stokes County Iredell County

Yadtin Count: 837.50

Surry County
$\$ 32.50$ $\$ 32.50$

537.50

$\$ 42.50$
Rockingham Co. \$42.50

Wilkes County

Alleghany $\mathrm{Co}_{0}$.

Davidson $\mathrm{Co}_{0}$.

$\$ 37.50$

$\$ 37.50$

$\$ 47.50$

N.C. Residents Add 41/5 Sales Tax 


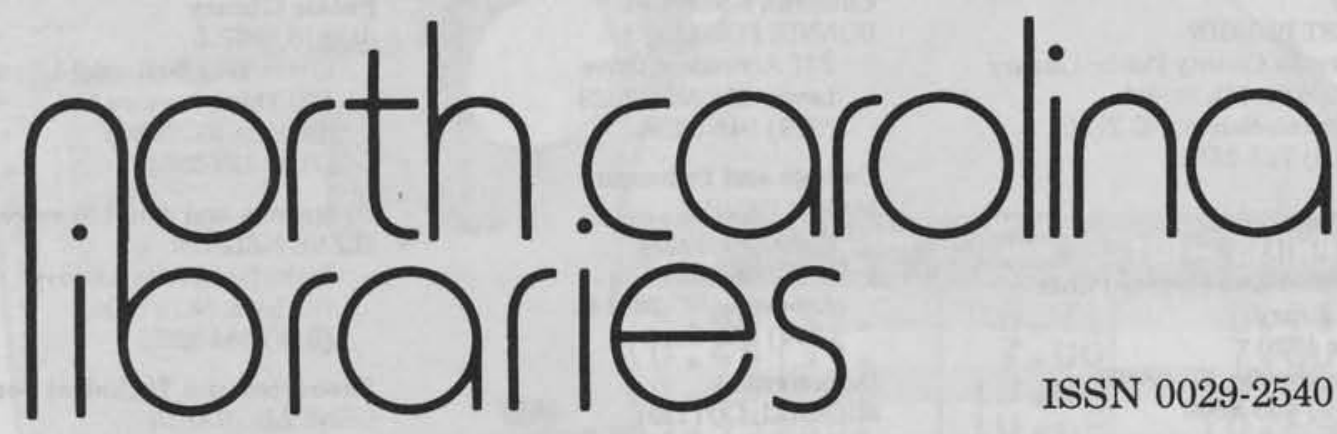

\section{TABLE OF CONTENTS}

\section{Articles}

54 Introduction, John Welch

55 Library Networking in North Carolina: The Sharing Mission, Marjorie W. Lindsey

58 Zones of Cooperation: Aspects of Network Development, Ruth M. Katz

61 The State Library and LAMBDA, Eunice P. Drum, Joel Sigmon, and Denise Sigmon

66 Library Networking: A School Library Perspective, Mary P. Holloway

68 The Triangle Research Libraries Network, Joe A. Hewitt

73 The North Carolina AHEC Network, Lymne Siemers

78 The Walter R. Davis Library, Larry Alford

\section{Features}

52 From the President, Leland M. Park

85 New North Carolina Books

92 NCLA Minutes and Reports

Cover: John Welch, "Introduction," North Carolina Libraries 42 (Summer 1984): 54. This issue focuses on the many networking projects in North Carolina's libraries.
Advertisers: Baker \& Taylor, p. 51; Ebsco, p. 53; Freedom to Read Foundation, p. 53; Hunter Publishing Company, Cover 2; MacGregor, p. 54; National Geographic, Cover 3; Phiebig, p. 53; Reprint Company, p. 57; Ruzicka, p. 65; Southeastern Microfilm, p. 90. 


\section{EDITORIAL STAFF}

\section{Editor}

ROBERT BURGIN

Forsyth County Public Library

660 West 5th Street

Winston-Salem, NC 27101

(919) 727-2556

\section{Associate Editor}

PATSY J. HANSEL

Cumberland County Public Library

Box 1720

Fayetteville, NC 28302

(919) 483-8600

\section{Associate Editor \\ ROSE SIMON}

Dale H. Gramley Library

Salem College

Winston-Salem, NC 27108

(919) $721-2649$

\section{Book Review Editor}

ALICE COTTEN

Wilson Library

UNC-Chapel Hill

Chapel Hill, NC 27514

(919) $962-1172$

Advertising Manager
JEFF SAUER
Hunter Library
Western Carolina University
Cullowhee, NC 28723
(704) $227-7485$

\section{Children's Services \\ BONNIE FOWLER \\ 237 Arrowleaf Drive \\ Lewisville, NC 27023 \\ (919) 945-5236}

College and University
MARIE DEVINE
Ramsey Library
UNC-Asheville
Asheville, NC 28814
(704) 258-6625
Documents
MICHAEL COTTER
J.Y. Joyner Library
East Carolina University
Greenville, NC 27834
(919) 757-6533
Junior Colleges
BEVERLEY GASS
Guilford Technical Community
College
Box 309
Jamestown, NC 27282
(919) 292-1101

Junior Members Roundtable

JOHN BURNS

Elbert Ivey Memorial Library

420 Third Avenue NW

Hickory, NC 28601

(704) 322-2905

N.C. Association of School
Librarians
FRANCES BRADBURN
Greensboro Day School
Box 9361
Greensboro, NC $27429-0361$
(919) $288-8590$

\author{
Public Library \\ BOB RUSSELL \\ Elbert Ivey Memorial Library \\ 420 Third Avenue NW \\ Hickory, NC 28601 \\ (704) 322-2905
}

Reference and Adult Services

ILENE NELSON

Duke University Library

Durham, NC 27606

(919) 684-2373

Resources and Technical Services

GENE LEONARDI

Shepard Library

North Carolina Central University

Durham, NC 27707

(919) 683-6220

Roundtable for Ethnic Minority

Concerns

SYLVIA SPRINKLE-HAMLIN

Forsyth County Public Library

660 West 5 th Street

Winston-Salem, NC 27701

(919) $727-2176$

\section{Roundtable on the Status of Women in Librarianship MARY McAFEE \\ Forsyth County Public Library 660 West 5 th Street \\ Winston-Salem, NC 27101 \\ (919) 727-2264}

\section{Trustees}

North Carolina Libraries, published four times a year, is the official publication of the North Carolina Library Association. Membership dues include a subscription to North Carolina Libraries. Membership information may be obtained from the treasurer of NCLA.

Subscription rates for 1984 are $\$ 20.00$ per year, or $\$ 5.00$ per issue, for domestic subscriptions; $\$ 25.00$ per year, or $\$ 7.00$ per issue, for foreign subscriptions. Backfiles are maintained by the editor. Microfilm copies are available through University Microfilms International. North Carolina Libraries is indexed by Library Literature and publishes its own annual index.

Editorial correspondence should be addressed to the editor; advertisement correspondence should be addressed to the advertising manager. Articles are juried.

North Carolina Libraries is printed by Meridional Publications, Wake Forest, NC.

Issue deadlines are February 10, May 10, August 10, and November 10. 


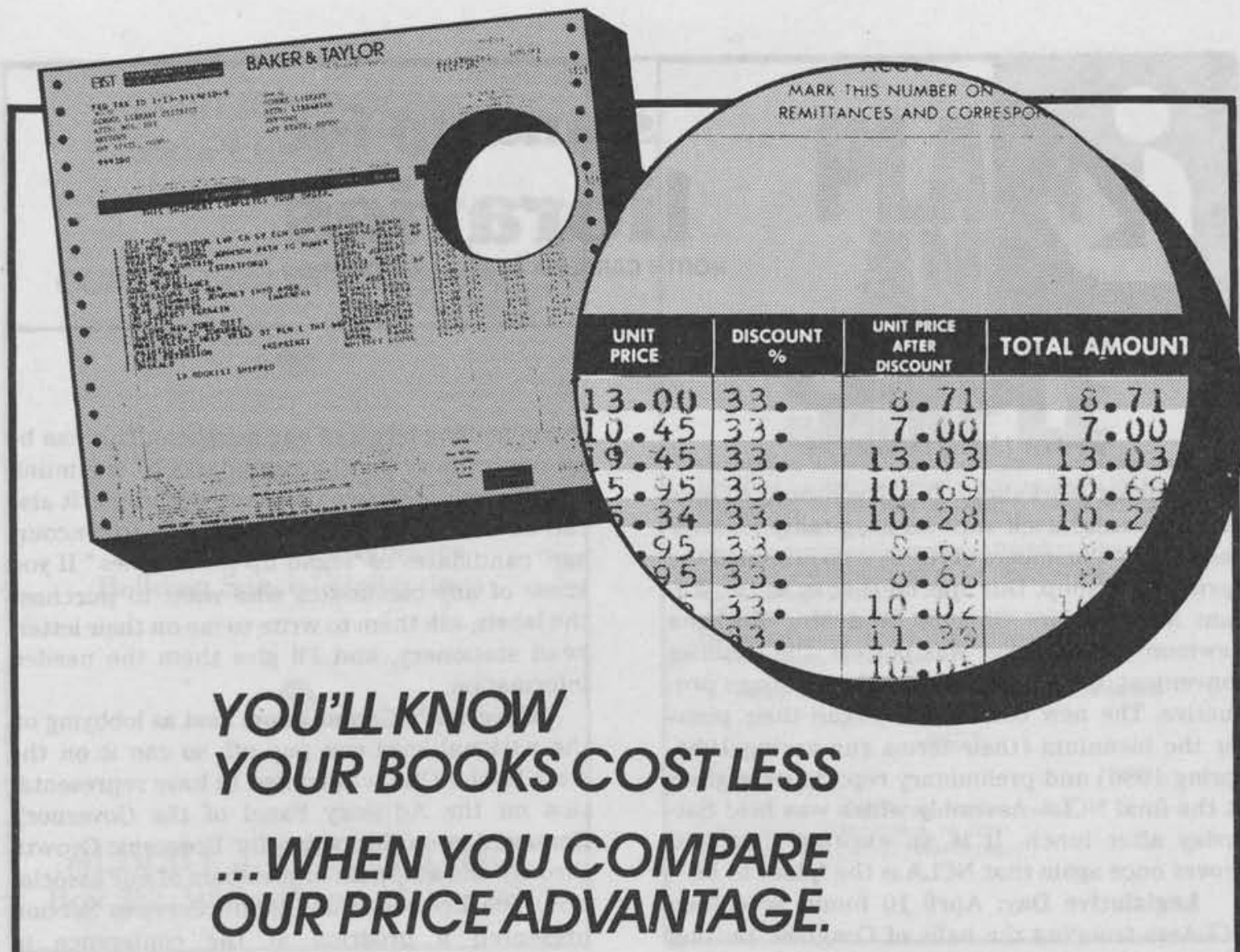

Baker \& Taylor will show you publishers' list prices, your earned discount, and the actual price you pay for every title ordered. Compare all our Budget Control Services including Do Not Exceed Ordering and our Quotation Service. You'll discover we offer lower prices and the most costefficient methods of stretching your purchasing power. And, we stock more titles than any other book supplier.

For details, contact the Sales Department of the division nearest you. 


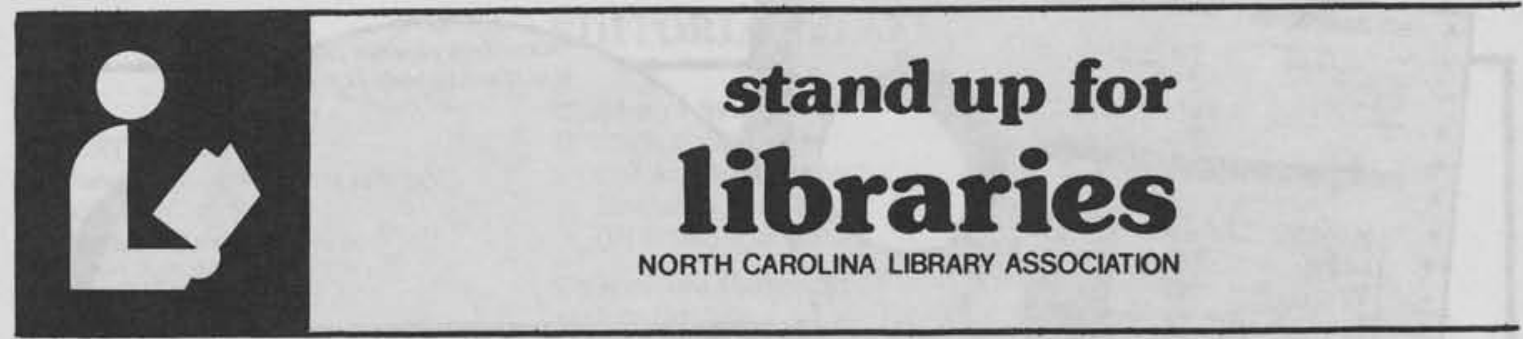

\section{From the President}

Spring Workshop: The Greensboro College Library outdid itself with its hospitality for over one hundred members of NCLA who attended the Spring Workshop. Our special thanks to Dr. William Mott, library director, and Mrs. Euthena Newmon. The weather was perfect, the facilities convenient, the food good, and the meetings productive. The new committees began their plans for the biennium (their terms run spring 1984spring 1986) and preliminary reports were given at the final NCLA Assembly which was held Saturday after lunch. It is an exciting time and proves once again that NCLA is the "place to be."

Legislative Day: April 10 found seventeen NCLAers trooping the halls of Congress, putting in a good word for library legislation on the national level. The trek was ably planned by Louise Boone, and she was joined by Artemis Kares, Nancy Massey, Pauline Myrick, Benjamin Speller, Arial Stephens, Jerry Thrasher, Judith Sutton, William Bridgman, Judie Davie, Henry Hall, J.A. Killian, Leland Park, Kieth Wright, Beverley Gass, David McKay, and Jane Williams. Everyone who participated in an ALA Legislative Day is impressed with the experience of being a part of the democratic process, "standing up for libraries" to those whom we have elected to represent us. And it pays off, too. At times when funding for library services comes under the most difficult attack, the Legislative Days have often helped save the day. Our thanks to Louise Boone and this group for representing us.

Elections: Now that the primaries are over and the candidates for the general election are chosen, remember to take any opportunity possible to "stand up for libraries" to the individual candidates. This is a crucial election for libraries in this state. The Executive Board passed a policy delineating the circumstances under which libraryrelated groups and political candidates may pur- chase mailing labels of our members. This can be an opportunity for the candidates to communicate directly with two thousand librarians. It also can be an opportunity for librarians to "encourage" candidates to "stand up for libraries." If you know of any candidates who want to purchase the labels, ask them to write to me on their letterhead stationery, and IIl give them the needed information.

Governor's Commission: Just as lobbying on the national level can pay off, so can it on the state level. NCLA was invited to have representation on the Advisory Panel of the Governor's Commission on Education for Economic Growth through the alterness of members of our association. The Reference and Adult Services Section presented a program at the conference in Winston-Salem based on the NC 2000 Report and reflecting state and national interest in curriculum reform. Also, RASS passed a resolution which was subsequently passed by the entire association asking Governor Hunt to involve librarians in curriculum reform in North Carolina. Following that, Ilene Nelson, chairperson of the 1983 RASS Program Committee, telephoned the director of the commission and asked him how librarians might become actively involved in the commission's work. An invitation was forthcoming shortly, representatives appointed, and the rest is history. NCLA had and has a role to play. And RASS is due much thanks for "Standing Up for Libraries."

Spring will have "sprung" and summer will be upon us when you read this. It has been a good year so far, and I hope for each of you a time of relaxation and reflection this summer. Have a good one.

Next Executive Board Meeting: July 20, 1984, High Point, NC.

Leland M. Park, President 


\section{FOREIGN BOOKS and PERIODICALS}

\section{CURRENT OR OUT-OF-PRINT}

\author{
3 \\ SPECIALTIES: \\ Search Service \\ Irregular Serials \\ International Congresses \\ Building Special Collections
}

ALBERT J. PHIEBIG INC. Box 352, White Plains, N..Y. 10602

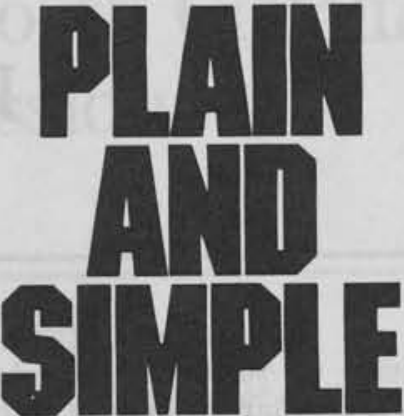

Our physical size and financial strength-necessary to make and honor commitments-indicate the successful working relationships we have with thousands of libraries worldwide.

But the plain truth is, simply, that it is our sensitivity to your unique requirements, and our flexibility in providing an exhaustive and relentless effort for total customer service that is our real strength.

We want to work with you-to help you provide exceptional patron service, which is your strength.

We can help. Write today-

\section{EBSCO SUBSCRIPTION SERVICES} The Serials Professionals

\section{=्र}

8000 Forbes Place, Suite 204

Springfield, VA 22151

(703) $321.7494 / 321.9630$

\section{Freedom to Read Foundation}

The battle is an important one. Today reports of attempts to censor books and information are at record highs. Any book, magazine, photograph or other material can be the target of would-be censors from the left. right or center.

Your membership in the Freedom to Read Foundation can make a difference in protecting the free flow of information and ideas - the basic principles of the First Amendment.

The Foundation is a 14-year-old organization of librarians, lawyers, educators, booksellers, authors. publishers and other concerned citizens who have joined together to safeguard the tradition of free expression in America. The Foundation provides legal and financial support to those at the frontline of censorship challenges.
Your membership in the Freedom to Read Foundation will:

- help support librarians across the nation who are beleaguered by raids on our libraries

- expand the freedom to read by offering legal and financial help in cases involving authors, publishers and booksellers

- entitle you to the Freedom to Read Foundation News, a quarterly newsletter on censorship trends. current court cases, legislative developments, and reports of successes in bouts with censors.

Books and ideas aren't dangerous but information restraints on a free people are. Protect the future of the First Amendment. Join the Freedom to Read Foundation.
Yes, I want to become active in the Freedom to Read Foundation. My membership check for \$ is enclosed. This tax-deductible contribution entitles me to vote for Foundation trustees and to receive the quarterly Freedom to Read Foundation News.

\begin{tabular}{ll}
$\square \$ 10$ student & $\square \$ 100$ sponsor \\
$\square \$ 25$ regular & $\square \$ 500$ patron \\
$\square \$ 50$ contributing & $\square \$ 1000$ benefactor \\
& \\
\hline Name & \\
\hline Address & \\
\hline City & State $\quad$ Zip
\end{tabular}

Please make checks payable to Freedom to Read Foundation and mail to Freedom to Read Foundation, 50 E. Huron St., Chicago, IL 60611. 


\section{Introduction}

This issue of North Carolina Libraries is devoted to examining the current status of some of the many networking activities taking place in our state. The term network is not easy to define. The dictionary definition of an "interrelated or interconnected chain, group or system" does not do full justice to the concept. Specifically, the dictionary definition does not show the dynamic nature of a network, that is, its ability to expand, contract, or change in order to fulfill specific needs. It is this very elasticity and vitality that give the concept of a network its greates potential. Mention the term network to a group of librarians and you will probably get as many different answers as there are people present. Most people would probably first tend to think of the large bibliographic and data base networks such as OCLC, RLIN, BRS, or DIALOG. However, as the 1982 King Research study on networking in North Carolina pointed out, the concept of a network also exists at much smaller levels and in less traditional ways than those just mentioned. The articles in this issue will call attention to the diverse types of networking in North Carolina-from TRLN and LAMBDA to the CLONE project and the AHEC library network.

In this issue, Marge Lindsey outlines the results that have been achieved by the various task force groups of the North Carolina Network Steering Committee. Ruth Katz reports on the results of the first two ZOC (Zone of Cooperation) grants that were selected by her task force group. SOLINET's experimental LAMBDA system is reviewed as an in-house network at the Division of State Library by Eunice Drum and Joe and Denise Sigmon. The potential for public school networking is presented by Mary Holloway. The current progress of the TRLN network, which may become one of the largest in the state, is presented by Joe Hewitt. Lynne Siemers discusses the work of an already existing special library network among the AHEC libraries.

What is the future for networking in our state? Will we develop a vast, integrated, multitype network of libraries or find that our network- ing needs are handled more efficiently by local or regional ZOCs? The answer to these intriguing questions will unfold for us as we continue to examine and experiment with networks. Whatever the final result may be, our current efforts are a good beginning to an exciting future.

\section{John Welch}

Public Library Consultant

Division of State Library

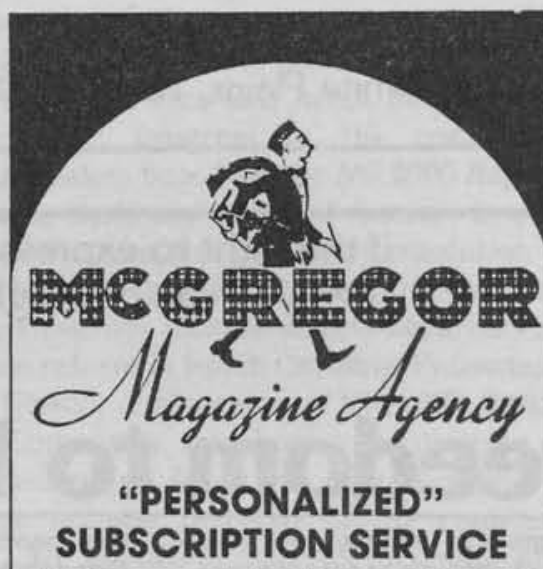

McGregor can simplify complex and time consuming problems of periodical procurement involving research, ordering, payments, renewals and record keeping. Prompt courteous service has been a tradition with McGregor since 1933.

- All domestic and foreign titles

- Title Research

- Prepaid Subscriptions

- Automatic Renewals

- Personal Service Representatives Call or write for catalog today $815734-4183$

MCGREGOR MAGAZINE AGENCY Mount Morris, Illinois 61054 


\title{
Library Networking in North Carolina: The Sharing Mission
}

\author{
Marjorie W. Lindsey
}

\section{Why Networking?}

Consider the following projections for North Carolina by the year $2000:{ }^{1}$

1.8 million people will be added to the state, for a total population of 7.7 million.

1 million households will be added, increasing the number of households by 47 per cent, while population increases by 30 per cent.

72 per cent of total state growth will be from people entering from outside the state.

The number of persons over age 65 will increase by 70 per cent, from six hundred thousand to one million.

How do we propose to serve this potential user population with our 2,639 libraries of some fiftytwo million volumes? This is the sharing mission of coordinated multitype library cooperation using appropriate technology -in short, networking.

Each type of library-public, school, academic, and special-has a distinct mission in meeting the diverse needs of North Carolina citizens. ${ }^{2}$ It is this diversity of patron demand beyond the capacity of a given library that sparks the sharing mission of interlibrary cooperation.

How are North Carolina librarians fulfilling this mission? Through personal networking with associations, committees, round tables, and user groups; through membership in SOLINET/OCLC, processing centers, and Zones of Cooperation (ZOCs); and through heavy use of the reference and interlibrary services of INWATS and the Information Services Section of the State Library. All of this works well, but with improvements in communications technology and the affordability of computers, there is a strong interest in making fuller use of these technologies for the enhancement of our sharing efforts statewide.

Marjorie W. Lindsey is Consultant on Multitype Library Cooperation for the Division of State Library in Raleigh. She is also Editor of Tar Heel Libraries.

\section{The Steering Committee}

Building on the work of earlier committees ${ }^{3}$ and on the recommendations of two studies, ${ }^{4}$ the North Carolina Library Networking Steering Committee was organized in October 1982, with representatives from the North Carolina Library Association, the North Carolina Chapter of the Special Libraries Association, and from all types and sizes of libraries from all parts of the state. (See Appendix A.) The deliberations of the committee are supported by the many hours of hard work by several task forces. Each steering committee member serves on a task force; each task force includes representatives of at least two types of libraries. The steering committee and the task force chairs meet quarterly; the task forces meet as often as required to fulfill their charges, submitting quarterly reports to the steering committee. The committee submits an annual report to the State Library Commission. Minutes of steering committee meetings and all reports are on file at the State Library. All members of the committee and task forces serve voluntarily for a minimum of two years.

\section{The Task Forces}

The Task Force on the Bibliographic Database has produced a document developing a building-block concept for the growth of a statewide data base, recommending a MARC or MARCcompatible communications format, and encouraging libraries using OCLC to catalog materials at OCLC level I standards. Accompanying this document are three papers on (1) conversion of bibliographic records to machine-readable form; (2) MARC formats; and (3) automation options for nonautomated libraries. Copies are available from the State Library on request. Currently the task force is studying the feasibility of producing a North Carolina statewide union list of serials, one among its several charges.

In October 1983, the Task Force on Continuing Library Education recommended that a more closely defined Task Force on Education and Training would be more useful for the networking 
effort. The steering committee approved the recommendation to dissolve the original task force and to activate and staff the new group when appropriate.

The Task Force on Document Delivery has looked at several commercial and governmental delivery systems currently in use in the state, as well as facsimile transmission. To determine the effectiveness of present interlibrary loan and document delivery processes, the task force has developed a survey instrument to measure the time required for completion of each transaction. The instrument will also gather data allowing for study of the subject areas and type of document borrowed and the form of document supplied. Efforts are currently underway to test this survey instrument with the thirty-eight libraries participating in the western $\mathrm{ZOC}$ project, the Union List of Periodicals in Libraries of Western North Carolina. Consideration of broader use will follow test evaluation.

The 1983 Task Force on Funding developed a brief manual to assist in funding a ZOC. Presently the task force is studying initial and continuing costs that may be incurred, funding requirements, and possible strategies needed to establish a statewide network.

\section{It is this diversity of patron demand beyond the capacity of a given library that sparks the sharing mission of interlibrary cooperation.}

The Task Force on Public Information developed a promotional brochure in time for distribution at the October 1983 North Carolina Library Association Conference. Currently the task force is preparing exhibit materials for use at various library meetings across the state and will be responsible for brochures, briefing papers, and other media needed to inform librarians, trustees, library users, governmental officials, and the general public about statewide library networking.

The Task Force on Technology, building on earlier reports, is identifying several basic assumptions regarding the purpose, services, and products of a statewide network. For example, the network should provide access to a master data base for all interested libraries; should provide a means of conducting interlibrary loan transactions and a mechanism to facilitate document

delivery; should provide for future developments in electronic mail and possible personal or home access. The network is not envisioned as a bibliographic utility. The task force is examining several possible configurations and will draft a technological design and schedule for a phased development of a statewide library network.

The Task Force on ZOCs is perhaps the most visible at the present time. Grants for two pilot ZOCs, funded by Title III of the Library Services and Construction Act, were awarded in 1983, and it is hoped that by the summer of 1984 at least two more grants will be awarded. Through the 1984-85 term the task force will draft for discussion a design of the organizational structure of a statewide library network and coordinate the work of the other task forces to develop a discussion draft of a total network design with phased implementation.

\section{How You Can Be Involved}

What network configuration do you think is most feasible? What should a network offer you? What do you think is a reasonable cost for the benefits derived? What are some realistic funding strategies? What is the relevance of this enterprise for library service in North Carolina?

Now, during the period of brainstorming, discussion, design, and planning, is the most appropriate time for you to send your comments and suggestions, and those of your users, to the Steering Committee and task force chairs.

Let us hear from you; be involved; think networking!

\section{References}

1. "NC 2000, Our Future Begins Now...," brochure (Raleigh: Commission on the Future of North Carolina, 1981).

2. North Carolina Libraries, Their Role: Statements of Mission and Purpose (Chapel Hill: UNC Press, 1983).

3. The North Carolina Library Association Networking Committee, the Ad Hoc Committee on Multitype Library Cooperation, and the Technical Subcommittee of the Ad Hoc Committee.

4. Alberta Smith, Access to Information for North Carolinians, Multitype Library Cooperation (Raleigh: Division of State Library, 1981), Jose Marie Griffiths and Donald W. King, North Carolina Library Networking Feasibility Study (Rockville, Maryland: King Research, Inc., 1982).

Appendix A

North Carolina Library Networking Steering Committee 1983-1985

Representative of President of NCLA

Chair, NCLA Trustees Section
Arial Stephens, Director, Richard H. Thornton Library, Oxford

Representative Dorothy Burnley, High Point 
TRLN Representative

County Public Library

Regional Public Library

Municipal Public Library Mary Boone, Director, Chapel Hill Public Library

Academic Libraries (East N.C.)

Academic Libraries (West N.C.)

Community Colleges

Public Schools

Special Libraries Association

Director, Division of State Library

Ruth Katz, Director, Joyner Library, East Carolina University, Greenville

Louise Rountree, Livingstone College Library, Salisbury

Betty Williamson, Associate Dean of Instruction, Learning Resource Center, Fayetteville Technical Institute

Elsie Brumback, Assistant State Superintendent Area Support Services, Department of Public Instruction, Raleigh

Anne Stringfield, Librarian, Lorillard Research Center Library, Greensboro

Assistant State Librarian Jane Williams

State Library Consultant

for Multitype Library

Cooperation

Marjorie Lindsey

\section{Task Force Chairs}

Task Force on Bibliographic Data Base

Task Force on Document Delivery

Task Force on Funding

Task Force on Public Information

Task Force on Technology

Task Force on ZOCs
Carol Myers, Head, Technical Services, Public Library of Charlotte/ Mecklenburg County

Nell Waltner, Head, Acquisitions, D. H. Hill Library, N.C. State University, Raleigh

\section{I.T. Littleton (see above)}

Carol Lewis, Director, Division of School Media Programs, Department of Public Instruction, Raleigh

William Gosling, Assistant University Librarian for Technical Services, Duke University, Durham

Ruth Katz (see above)

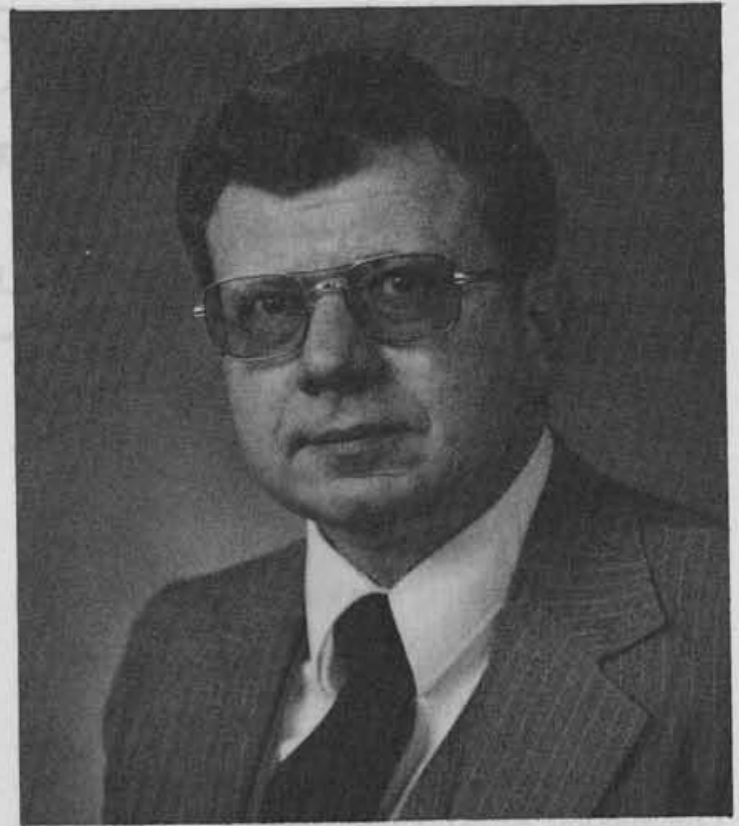

Robert N. White, administrator of the Utah Personnel Review Board, will be the featured speaker at a workshop entitled "Documentation-the Good, the Bad, and the Ugly." The workshop will be held July 26 and 27 at the Forsyth County Public Library in Winston-Salem and is sponsored by the Round Table on the Status of Women in Librarianship.

\section{REGIONAL LOCAL HISTORY GENEALOGY.}

PUBLISHERS and BOOKSELLERS of reprints and originals ... Regional and County History, Genealogical source material, Colonial Americana, Revolutionary and Civil War material ... Primary emphasis on Southeastern states ... Publications of the South Carolina Historical Society and North Carolina Genealogical Society. Write for complete catalogue.

Thomas E. Smith

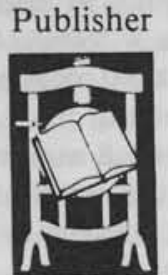

THE REPRINT COMPANY, PUBLISHERS

Post Office Box 5401

Spartanburg, S.C. 29304 


\title{
Zones of Cooperation: Aspects of Network Development
}

\author{
Ruth M. Katz
}

In North Carolina, network development and multitype library cooperation that will lead to improved library and information service for our citizens are the shared responsibility of the Division of State Library, ${ }^{1}$ individual librarians, and the various governing and advisory groups having a role in library funding and development. The specific goal of developing a comprehensive plan for statewide network development has been assigned to the North Carolina Library Networking Steering Committee by the State Library Commission. More detailed information about the Steering Committee and its work appears elsewhere in this issue.

The Steering Committee believes that activities that should be addressed in a statewide plan include, but are not limited to, building a statewide data base, encouraging zones of cooperation (ZOCs), employing appropriate technology, improving document delivery, addressing education and training needs, estimating funding requirements and developing a public information program. Task forces organized by the Steering Committee are focusing on each of these topics. At this time, forty librarians are involved in committee or task force deliberations. The base upon which the current effort builds includes the work of the State Library Ad Hoc Committee for Multitype Library Cooperation, the NCLA Networking Committee and the King Research Inc. (KRI) study of networking feasibility.

Although the acronym ZOCs caught on very quickly, not everyone who served on the Steering Committee or who read the KRI report had a good idea of what a ZOC might be. Originally described by KRI as a "zone of convenience," the definition was changed to "zone of cooperation" to improve understanding.

ZOCs are best seen as a way of organizing for cooperative activities without loss of independence by individual libraries or of the ability to set

Ruth M. Katz is Director of Academic Library Services, Joyner Library, East Carolina University. She is a member of the North Carolina Library Networking Steering Committee and chairs the Task Force on ZOCs. and change priorities. A group of libraries form a $\mathrm{ZOC}$ and share resources when it is convenient for them to do so. Factors affecting convenience include, but are not limited to, geographic proximity, similarities in types of patrons, dissimilarities in collections, existing cooperative relationships, and special relationships among libraries or librarians. ZOCs provide needed flexibility in establishing a statewide network because a library can belong to more than one $\mathrm{ZOC}$ and because membership within a $\mathrm{ZOC}$ can change over time as the needs or priorities of member libraries change.

\section{Request for Proposal}

With help from the Steering Committee and the two active task forces, the Task Force on ZOCs worked to develop recommendations for a pilot project similar to that suggested in the King Research Inc. study. When the Division of State Library made a commitment to allocating some anticipated LSCA funds to one or more pilot projects, the idea of developing a Request for Proposal (RFP) and soliciting grant applications through the RFP process was finalized.

The task force identified several points it considered essential for the development of pilot projects and, with the approval of the Steering Committee, incorporated these in the RFP. The key points are that projects should include two or more types of libraries (with school library participation seen as highly desirable), encourage local cooperative ventures, provide spinoffs for statewide use (e.g. machine-readable files in MARC format), and lead to improved products and services to users-including other libraries. These and other eligibility factors appeared in the RFP as did detailed guidelines for preparing and submitting a proposal. The third part of the RFP described how proposals received by the Task Force on ZOCs would be evaluated and listed evaluation criteria in each of five general categories: likely impact of the proposed project on a need defined in the proposal, attainability of proposed objectives, adequacy of management plan, appropri- 
ateness of budget and likelihood of ongoing commitment.

When the RFP was finalized and approved, the Division of State Library and the Department of Public Instruction distributed it to libraries and school systems throughout the state. The availability of the RFP was announced in Tar Heel Libraries and other newsletters so that any interested individual could obtain a copy by contacting the State Library.

All indications are that the process worked very well. Seven proposals were received for review. Two of these were selected for funding and the first contracts were awarded in October 1983.

When the 1983-85 Steering Committee and the task force chairmen met in October 1983, new work agendas were distributed and the membership of each task force was finalized. It was clear that the amount of work was increasing, that communication and cooperation among the task forces were absolutely necessary, and that the complex issues facing the Steering Committee would require a considerable amount of intense discussion. In other words, the existence of two pilot projects moved statewide networking from a feasible concept to a practical reality.

The Task Force on ZOCs had an immediate need to develop and release the second RFP for model ZOC projects to be funded for state fiscal year 1984-85. This work was accomplished in February 1984. Evaluation of the two operational ZOCs also was a high priority task. This work is being accomplished with the assistance of other task forces-both project monitoring and project technical assistance are provided to the pilot ZOCs. The results will be documented for use by other ZOCs and for consideration in a proposed organizational design for a statewide library network.

\section{Project Clone}

A brief description of the work underway by the pilot ZOCs will illustrate some of the early benefits of multitype library cooperation. Five libraries in Nash and Edgecombe counties have joined together to develop a union COM catalog of their combined monographic collections-about 166,000 titles. Microfiche readers are already available at the libraries (Edgecombe Technical College, Edgecombe County Memorial Library, Nash Technical College, North Carolina Wesleyan College, Braswell Memorial Library) and at all the high schools in the two counties. The participating libraries are located in a small geographical area but local citizens would not have true access to the combined collections without a union catalog. The project is named CLONE, standing for Cooperative Libraries of Nash-Edgecombe.

In the early stages of the project, the participating librarians got input from potential vendors and from State Library staff to help them understand about costs, data base maintenance, retrospective conversion and the establishment of catalog policies and guidelines. The CLONE team decided to produce a two-way divided catalog (author/title, subject), to use NCUC symbols already assigned to the libraries, and to designate one of the public libraries as the authority control center for the union list project. Member libraries agreed to have their individual catalogs updated quarterly. The union catalog will be updated semi-annually. The frequency of update can be changed if it proves to be unsatisfactory.

One product already available from Project CLONE is a questionnaire used to evaluate the capabilities of potential COM catalog producers and to solicit cost estimates.

\section{Western NC Project}

The second pilot $\mathrm{ZOC}$ includes thirty-eight libraries located in twenty-three western North Carolina counties. The participants have a long history of cooperation, including compiling a union list of periodicals, but can no longer support projects through use of regular staff members and students and with simple data processing equipment made available by the institutions in which the libraries are located. From 1975, when the fourth edition of the union list appeared, to 1983 , the number of libraries increased from 20 to 38 and the number of periodical titles increased from 6400 to 7000 . The large population served by participants in this project $(615,000)$ and the uniqueness of the collections held by some of the libraries should make the product useful throughout the state. The methodology proposed for merging serials holding data from a variety of formats should be useful to other groups of libraries. The union list will be built from the holdings of Western Carolina University, University of North Carolina at Asheville, and Appalachian State University. Then holdings data for the Historical Foundation of the Reformed Presbyterian Churches will be added. The Foundation collection of 1700 unique and mostly out-of-print titles is the fourth largest serials collection in the region. It is estimated that the four libraries hold 90 per cent of the titles in the region. Additional details about methodology, 
fees, and working arrangements with the contractor (SOLINET) are being distributed by the project office.

The Western North Carolina Project is being assisted by the Task Force on Document Delivery whose members have designed a study methodology to gather data on interlibrary borrowing and lending and on document delivery. The methodology will enable the participants to study the effects of a new edition of their serials union catalog as soon as it is delivered. If data collection is implemented rapidly, baseline data from the previous edition of the union catalog also may be available. Instructions for implementing and standardizing data collection have been prepared. This will be another product available for statewide study and use.

\section{Conclusion}

The pilot ZOCs described above are the first visible results of the effort toward statewide library networking. When a second group of model projects is selected in June of this year, the variety of $\mathrm{ZOC}$ groupings and range of projects available for site visits and discussion by librarians should be adequate to move the networking plan ahead at an accelerated pace. The task forces, especially the one concerned with technology, are continuing to address the question "what do librarians want the network to be/do?" Much work is being done toward identifying a technological design and a time frame for phased development of a network.

Many other topics remain to be addressed. It is generally agreed that the technical feasibility of networking has increased greatly and that economic feasibility is improving with leadership coming from the private sector. More attention now should be focused on the professional and political impacts of networking. Some of the questions are

Will competition among libraries for funds reverse the trend toward networking and resource sharing?

How will local governments perceive the changing roles and funding needs of "public" libraries in schools, community colleges, universities, and of municipal public libraries?

What changes may be needed in the organization of libraries and the use of library facilities?
What will happen to the relationships between libraries and private sector providers such as publishers, bookstores and data base vendors?

The already established ZOC projects and the newly funded model ZOC projects that will operate in 1984-85 will provide many of the answers to these questions. Then the task forces and the Steering Committee can derive decisions and recommendations from field-based knowledge.

The Steering Committee is devoting a major part of its calendar year 1984 agenda to gathering input and exploring options for network development. Care will be taken not to impose a grand design that limits the options of individual libraries or groups of libraries. Librarians throughout our state can participate in the network development process by visiting $\mathrm{ZOC}$ field sites, following published reports of networking activities, discussing the concepts and the specifics that are being proposed and directing questions and ideas to the State Library for use by the Committee and its task forces.

\section{References}

1. North Carolina General Statute 125-2(10) lists the following among the duties of the Department of Cultural Resources, under which the Division of State Library operates: "To plan and coordinate cooperative programs between the various types of libraries within the State of North Carolina, and to coordinate State development with regional and national cooperative library programs."

\section{Errata}

A typographical error appeared in Renee Taylor's article, "The Employee Perspective in the Evaluation Process," which was published in the Spring 1984 issue of North Carolina Libraries (pages 12-14).

The first four sentences of that article should have read as follows: "Evaluations. No one is ecstatic about making or receiving them; however, they are necessary. When the time approaches for my work to be evaluated, I usually become a bundle of nerves and eagerly anticipate the end of the ordeal: Not until this year, when I became a member of my library's performance appraisal committee, did I know that supervisors dread the process too."

The editor regrets the error. 


\title{
The State Library and LAMBDA
}

\author{
Eunice P. Drum, Joel Sigmon, and Denise Sigmon
}

\section{Introduction}

From April 1 through September 30, 1982, the North Carolina State Library participated in a field test of the Southeastern Library Network's LAMBDA system. (LAMBDA is an acronym for Local Access to and Management of Bibliographic Data and Authorities.) Ten other libraries, including seven academic, one medical, one public, and one special, also participated in the test. The libraries in the test group represented a cross section of the SOLINET membership.

The State Library took part in the field test to demonstrate LAMBDA to other North Carolina libraries and to evaluate its usefulness in establishing an automated statewide network. LAMBDA has been demonstrated by the State Library staff to over one hundred librarians from twenty-one libraries in North Carolina. These demonstrations were well-received and were intended to illustrate the potential of an on-line system with capabilities similar to LAMBDA for the proposed North Carolina library network.

LAMBDA offers four distinct services: reference support (including a user friendly patron access mode), institutional bibliographic data base management, authority control, and editing of holdings information. Each of these services is discussed later in the context of its routine use by the various areas of the State Library. LAMBDA is available from 9:00 a.m. to 10:00 p.m. Monday through Friday and 9:00 a.m. to 6:00 p.m. on Saturday.

The State Library's OCLC archival tapes are loaded into LAMBDA weekly. In order to save money and computer storage space, linkage bibliographic records are used rather than the State Library's own records. Thus, if a record for a particular work already exists in the data base, the State Library's holdings are simply attached to

Eunice P. Drum is Chief of Technical Services for the Division of State Library in Raleigh. Joel Sigmon is INWATS Librarian in Interlibrary Services for the Division of State Library. Denise Sigmon is Acquisitions Librarian in Technical Serv. ices for the Division of State Library. that record. Of course, the State Library's record is loaded when no other record for the work is already in the data base.

The following statistics show the number of records reviewed, the number of changes made, and the number of searches performed during the test period:

$\begin{array}{lr}\text { Total records reviewed } & 17,572 \\ \text { Bibliographic records changed } & 2,114 \\ \text { Authority records changed } & 1,651 \\ \text { Holdings records changed } & 287 \\ \text { Total records not changed } & 13,807 \\ \text { Reference searches } & 1,127\end{array}$

As indicated by the high number of records requiring no change ( 79 per cent), the integrity of the dta base is quite good. Relatively few holdings records were changed because the capability of editing holdings information was not available at the beginning of the test period.

Since the field test, LAMBDA has been incorporated into the daily activities of the Interlibrary Services Branch, the Reference Services Branch, and the Technical Services Section of the State Library. A description of the hardware used, the training required, and the application of LAMBDA to State Library routines follows.

\section{Hardware}

Two of OCLC's Beehive 105 terminals provided access to LAMBDA during the field test and are currently used by the Technical Services Section. Each terminal is connected to a General Electric Terminet 1232 printer. A Codex MX2400 modem links both terminals to a dedicated telephone line for data transmission. A switching mechanism allows the terminals to be connected interchangeably with OCLC or LAMBDA.

Two Burroughs ET 1100 video display terminals were installed in the fall of 1983 for use by the Interlibrary Services Branch and the Reference Services Branch. One terminal is in the INWATS office of the Interlibrary Services Branch; a second terminal is in the main reading room. Both terminals are served by a Codex MX2400 modem housed in INWATS. A dedicated tele- 
phone line to SOLINET is used for data transmission. (Dial access to LAMBDA is available, but a dedicated line is more practical for the State Library's purposes.) Each terminal is connected to a NEC Spinwriter 7715 printer. Unlike the terminals now used by the Technical Services Section, the Burroughs terminals cannot be switched to OCLC.

\section{Training}

LAMBDA is not difficult to operate, especially for those with prior experience searching other information retrieval systems. When the State Library became a participant in the field test, seven staff members from Technical Services and one from Interlibrary Services attended a SOLINET training session. These persons then trained other State Library staff.

The Interlibrary Services staff designed an inhouse training program, consisting of two onehour sessions of classroom instruction and one thirty-minute session of hands-on training. This program was used to train the other staff members of the Interlibrary Services Branch and the librarians of the Reference Services Branch.

\section{Use of LAMBDA by the Interlibrary Services Branch}

LAMBDA's search capabilities are well suited to the routine information retrieval operations of the Interlibrary Services Branch. A unit of the Information Services Section, the branch links North Carolina's library resources to users by serving as a clearinghouse and switching center for the state's network of libraries. Materials owned by the State Library are supplied to local libraries; requests not filled from the State Library's collection are referred to other libraries or organizations in North Carolina. In carrying out its function, the branch searches for specific titles in various formats and answers a wide range of reference questions. Approximately twelve hundred requests are searched each week. LAMBDA has been integrated into the routines of the branch on an experimental basis in an effort to speed processing, improve searching efficiency, and broaden the scope of material available to its users.

The Interlibrary Services Branch began using LAMBDA routinely in the fall of 1983 . Prior to that time, SOLINET did not load records weekly into the data base, retrospective conversion had not progressed sufficiently to make LAMBDA viable as an on-line catalog, and the Interlibrary Services staff shared terminals with the cataloging staff. These factors prevented the branch from fully incorporating LAMBDA into its routines earlier. Use was thus limited initially to searching for titles not verified elsewhere and for information on topics not easily accessible by other means.

Information retrieval functions of LAMBDA. In reference work, LAMBDA may be used as an on-line catalog and shelflist, an on-line thesaurus of search terms, and an on-line union catalog. The system may be searched either in the inquiry mode or in the patron access mode. A few simple commands must be learned to operate the system in inquiry mode. In the patron access mode, the system supplies the commands automatically and provides help screens which give instructions for searching; the user has to enter only the search statement. The Interlibrary Services Branch operates the system using inquiry mode commands to avoid waiting for the help screens to appear. Specific capabilities of LAMBDA's information retrieval functions and their use by the Interlibrary Services Branch are summarized below. Examples of actual searches are included.

On-line catalog/shelflist. Because about 90 per cent of the State Library's collection is presently in the LAMBDA data base, the branch's staff searches LAMBDA rather than the card catalog whenever possible. Serials in reference and genealogical materials added to the collection prior to 1975 are not yet in the data base and are searched in the card catalog. In a typical week in January 1984, the branch searched 1,018 titles and 143 reference questions in LAMBDA.

As an on-line catalog and shelflist, LAMBDA offers a wide array of access points which are enhanced by Boolean connectors and truncation of word endigns. Access points include RID (Record Identifier, which is the same as the OCLC control number), Library of Congress card number, ISBN (International Standard Book Number), ISSN (International Standard Serial Number), title keyword (as part of the title proper or added entry), author (as the main or added entry and including keywords in corporate or conference names), subject heading, series titles, and call number.

Keyword searching and truncation are particularly useful features for interlibrary loan processing. Frequently the staff searches unverified titles containing inaccurate information. The keyword searching and truncation capabilities of LAMBDA increase the likelihood that univerified titles are found. For example, a patron requested a book discussed on the "Phil Donahue Show." He remembered the author's last name was Levinson and that the book had the word dyslexia in the title. By entering a search into LAMBDA which 
combined the author's last name (truncated) and the keyword of the title, the desired book by Harold N. Levinson entitled Solution to the Riddle Dyslex$i a$ was retrieved.

When searching for materials entered under a corporate or conference name, the searcher does not have to determine the established form of the name. Keywords can be entered into the system in any order to retrieve the desired item. For example, when searching for the proceedings of the $3 \mathrm{rd}$ Specialists' Meeting on Reactor Noise, the staff entered the keywords 3 rd reactor noise as a keyword in conference name search to retrieve the desired item. It so happened that the established form of the name (pre-AACR2) for this conference was Tokyo (Japan). Reactor Noise, Specialists meeting (3rd : 1981). The advantage of keyword searching for corporate or conference names is readily apparent.

When researching a topic, keyword access offers a shortcut to retrieval of relevent items. For example, when searching for information on satellite television reception, the keywords satellite television entered as a title search produce relevant material instantly. A subject approach to retrieving this information is much more cumbersome because valid Library of Congress subject headings for this concept include such esoteric terms as Earth stations (Satellite telecommunication) and Artificial satellites in telecommunication. Once relevant information is retrieved by searching keywords in titles, the subject headings in the tracings are entered into the system to retrieve additional relevant items.

The ability to enter an entire word or group of words into the system, rather than being limited (as in OCLC) to a few characters, provides a more specific and direct means of retrieving the information. In OCLC, for example, the title History of the American Theatre, 1700-1950 is entered as "his, of, th, a," resulting in a "request impossible" message from OCLC because of too many titles retrieved. In LAMBDA, the work can be retrieved by entering the title exactly as it appears or as various combinations of keywords. No additional qualifiers are needed.

Use of Boolean connectors (and, or, not) allows the searcher to specify relationships between or among terms, resulting in a more complete, accurate, and direct search than is possible in a card catalog or OCLC. In processing interlibrary loan requests, an author's name is frequently combined with keywords in a title to search for a particular work (e.g., the author's name John Steinbeck combined in an and relationship with the title keyword Americans to retrieve the book by Steinbeck entitled America and Americans). Another common use of Boolean searching by the Interlibrary Services Branch is the combining of a subject heading with title keywords to retrieve relevant works on a particular subject (e.g., the subject heading violin combined in an and relationship with the title keyword repair \# [\# indicates truncation] to retrieve materials on repairing violins).

Access to the shelflist is by Record Identifier. The information contained in the shelflist record includes local notes (e.g., price of the book, date purchased) and holdings (e.g., number of copies owned, which volumes of a multivolume work are owned).

On-line thesaurus. The LAMBDA authority file serves as an on-line thesaurus. Not only does it include the Library of Congress subject headings and name authority file, it also includes other headings appearing in a bibliographic record. This feature increases its usefulness for reference work. For example, NLM (National Library of Medicine) headings are included when attached to bibliographic records.

The authority file is interfaced with the bibliographic file, allowing the searcher to find in the bibliographic file a term retrieved in the authority file without retyping the search statement. This feature also permits searches not otherwise possible in the bibliographic file due to system limitations. One limitation is that a maximum of ten thousand items can be retrieved. Another is that when the system searches subject terms with subheadings, it searches subdivisions separately before combining them to produce a result. For example, the subject heading North CarolinaDescription and travel cannot be searched directly in the bibliographic file because the number of items assigned either the heading North Carolina or the subheading Description and travel exceeds the search maximum. It can, however, be searched by first locating the heading in the authority file and then retrieving those items in the bibliographic file assigned that unique heading.

The Interlibrary Services Branch generally searches the LAMBDA authority file in place of the printed Library of Congress subject headings when determining valid subject headings or cross references. In most cases using LAMBDA is faster than using the printed volumes, and the interface between the bibliographic and authority files described above makes it convenient.

Having the institution's own authority file instantly available also saves time. For example, AACR2 name changes, such as George Bernard Shaw's works being entered under Shaw, Bernard 
rather than Shaw, George Bernard, are readily tracked by searching the authority file.

On-line union catalog. Because the State Library is one of only two North Carolina libraries using LAMBDA, this function is not yet as useful as it could be. It does, however, have potential for a statewide automated system. The on-line union catalog operates in the same manner as the on-line catalog except that local notes and holdings information (i.e., the number of copies owned, which volumes of a multivolume work are owned) cannot be accessed for other libraries.

The chief benefit of the LAMBDA union catalog at present is that it provides the Interlibrary Services Branch with a good general bibliographic source. Nearly $1,400,000$ unique bibliographic records representing collections of various types of libraries are in the data base, greatly expanding the scope of easily searchable information for the branch. Once a record is retrieved, OCLC or the North Carolina Union Catalog is searched to determine North Carolina locations.

\section{Use of LAMBDA by the Reference Services Branch}

The Reference Services Branch of the State Library provides reference service to both state employees and other patrons visiting the main reading room. In addition, it maintains the library's circulation records. Unlike the Interlibrary Services Branch, the Reference Services Branch did not use LAMBDA until a terminal was installed in the main reading room in the fall of 1983 . The reference staff shares this terminal with the Interlibrary Services staff. These two factors have prevented the reference librarians from integrating LAMBDA fully into their routine activities. Nevertheless, they find it to be a helpful tool and anticipate that it will become more valuable in the future.

The reference staff performs forty to fifty searches per week, with keyword in title searches being the most frequent type. LAMBDA is used by the reference librarians primarily to locate specific titles when partial or inaccurate citations are provided by patrons. It is not yet extensively used in answering reference questions. Occasionally the staff generates bibliographies of works by a particular author or on a given subject.

While LAMBDA is not a circulation system, it assists with routine circulation procedures because of the shelflist information provided. The on-line shelflist (called the detailed holdings file in LAMBDA) is searched to determine the price paid by the State Library for publications when billing users for lost or damaged materials. It verifies which volumes of a serial or other multivolume work are in the State Library's collection. The number of copies owned is also indicated in the detailed holdings file. When a renewal is requested and the item is not found in the circulation file, a search by call number verifies if the State Library does indeed own the particular work.

\section{Use of LAMBDA by the Technical Services Section}

Regular cataloging maintenance is performed on LAMBDA by the Technical Services staff of the State Library. Errors in bibliographic, authority, and detailed holdings records are corrected when identified. Each type of record is updated and supplied with additional data when appropriate.

Changes made to bibliographic records include correcting typographical and tagging errors, filling in missing codes or fields (e.g., the MARC code 043 designating geographic area), and correcting other cataloging errors. Bibliographic records are altered automatically by the system whenever changes are made in the authority file. For example, adding a See Twain, Mark, 18351910 cross reference to the name and subject authority records for Samuel Langhorne Clemens changes all Clemens, Samuel Langhorne, 18351910 headings in the bibliographic records to Twain, Mark, 1835-1910.

Authority records are modified by updating headings to current usage, correcting typographical errors, adding death dates to personal name headings, supplying cross references to link the various forms of a heading, and adding explanatory notes (e.g., attaching brief agency histories to records for governmental bodies). If the currently accepted form of a heading does not exist in the authority file, a new authority record is created on a work form. Cross references from the incorrect or old form of the heading are included in the new record. By adding a used for cross reference to the new record, the system automatically supplies the corresponding see reference to the old record.

Detailed holdings records are reviewed systematically to verify and change as needed the call number, holding library location (i.e., reference, genealogy, oversize), local notes, and volume or copy information. Because the entire record must be re-edited on OCLC to change holdings information, the State Library does not routinely update holdings on OCLC. Thus the LAMBDA holdings records must be reviewed to make the needed changes. When errors are reported by the Reference Services Branch and the Interlibrary Services Branch, corrections are made. 
SOLINET is developing a library service program for small libraries. Because many small libraries already have microcomputers, a batch process for cataloging current acquisitions with a microcomputer will be offered initially. On-line capability will be available later. The State Library Processing Center plans to investigate the feasibility of automating its cataloging operations using SOLINET's service once on-line capability is instituted.

\section{Recommendations and Observations}

Recommendations for improving the information retrieval capabilities of LAMBDA include the following: adding the capability of specifying word order in title searches; providing a means of qualifying searches by date and by type of material; creating an index of titles, subjects, and corporate or conference names searchable by keyword; clarifying instructions in the patron access mode; and finally, expanding the system overall to increase the number of items that can be retrieved per search.

Cataloging maintenance functions can be improved in at least two ways. First, by replacing linkage records with the State Library's own records, the number of corrections needed will automatically be reduced. Second, editing time will be saved by simplifying the protocol for making changes to the data base (e.g., two screens must now be called up when changing detailed holdings records).

As the data base grows and improvements are made in access and maintenance capabilities, LAMBDA becomes increasingly useful to the State Library. All staff members using LAMBDA evaluate it favorably and find it genuinely helpful in their work. Generally, response time is good, and the system is down rarely. The staff looks forward to the continuing use of LAMBDA and eventual implementation of an automated statewide system providing similar capabilities.

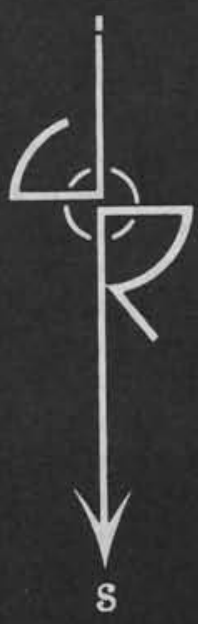

\section{Joseph Ruzicka South. Inc}

WHAT DO YOU LOOK FOR IN A BINDERY?

- Your collection deserves the binding excellence attained through 226 years experience.

- Certified by the Library Binding Institute, we offer you a choice.

- Select Class " $A$ " binding or try our Superflex.

- Both are fully guaranteed in materials and workmanship.

SERVICE, QUALITY, AND FAIR PRICES... THE RUZICKA WAY.

Come by for a personal tour of our facilities.

Call or write for particulars.

911 Northridge Street • P. O. Box 21568 • Greensboro, North Carolina 27420 Telephone (919) 299-7534 


\title{
Library Networking: A School Library Perspective
}

\author{
Mary A. Holloway
}

Networking, access, cataloging standards, AACR2, and OCLC-how and why do these relate to school library/media centers? To answer that question, one must consider the role of the school library and its needs in relation to the network.

The library media center has two salient functions. It provides an organized body of resources to support the school's curriculum and instruction, and it has an instructional role for its students, faculty, and staff. To accomplish these functions effectively, all of the more permanent media resources of the school should be cataloged for easy access with a master catalog of the collection as the point of entry for users.

The establishment and maintenance of the catalog consume precious time. With several systems networked, a central ordering and processing task could be more efficient. The Greensboro City School System has a central processing service for its schools. The system, a member of OCLC, not only purchases, processes, and distributes to each school prepared library materials but also receives catalog cards as a by-product of the membership and use of the OCLC data base. Using the terminal, the central staff can also locate the system's total holdings and determine which schools house a specific title or the number of copies of a title available.

Access to these services and to a machinereadable data base could have great benefits not only at the individual schools but also at the system level when there is a need to share resources and to reorganize collections. These procedures could then be planned with complete, accurate data and completed with dispatch.

Three important features of this system need to be noted. First, the volume of services of the processing center needs to be extensive enough to warrant the cost. The result, of course, is that records will then be in a standard format acceptable for inclusion in a network and for electronic search and sharing.

Mary A. Holloway is Assistant Director of Media Evaluation Services for the North Carolina Department of Public Instruction.
The competency goals and performance indicators of the Department of Public Instruction state that students should be introduced to resources beyond the school level, which may include the public library, on-line research services, academic libraries, or other community resources. To complete this task successfully, the school library needs to have some method for communicating easily with other school libraries and the larger world of public, university, and special libraries. A pilot Zone of Cooperation project, called CLONE, offers a networking model for providing student awareness of the community library resources available to them. The participating members (Edgecombe Technical College Library, North Carolina Wesleyan College Library, Braswell Memorial Library, Edgecombe County Memorial Library) plan to provide microfiche copies of their COM catalog to the high schools in the area.

The removal of time-consuming technical chores frees the media professional to assist in the greater use of all resources, both in-house and outside. If entering a statewide network that recognizes these concerns and that maps strategies for levels of participation can help school libraries, such a move should be considered.

When considering a network, whether it be local among school, public, and community college libraries, or regional among public, special, academic, and school libraries, public schools have three desirable assets of numbers, print and nonprint collections, and equipment.

First, the 1983 Annual PPAR Report records 2,014 school-libraries in North Carolina with approximately seventeen hundred full-time media personnel backed by strong state-level support for them in the Department of Public Instruction, Educational Media and Technology Area. By providing access for all citizens, school libraries offer an entry point to many resources. This fact does not negate the primary intent for these materials, to support the instructional program, but rather enhances their value.

The second asset of school libraries is the availability of resources of both print and non- 
print resources, as well as the equipment for using films, videotape, and other audiovisual media. Since educators recognize students' different learning styles, school collections of audiovisual materials reflect the need for a greater variety of media than do other types of libraries. With the increased emphasis on literacy, these resources have educational value for both students and adults.

Finally, if the experience of the staff at the Media Evaluation Center of the Department of Public Instruction is accurate, many schools and school libraries are developing microcomputer courseware collections, another significant medium for accommodating learning styles. The microcomputer may be the technology needed to meet the networking goals.

\section{Conclusion}

In her doctoral dissertation, "The Role of the School Library Media Program in a Multitype Library Network," Barbara Immroth states that "the actual experience of the participants in Colorado demonstrated the ability of a multitype library network to successfully include schools." To be a part of the total library picture in North Carolina's network, what preparations should school libraries make now and in the future?

Short-range plans. Establish working relationships with building level administration, faculty, and students to share knowledge of networking potential.

Establish human networks locally, regionally, and statewide to share ideas and expertise with other professional librarians.

Encourage system-level interaction with those who have media responsibilities.

Be cognizant of the process and its implications for the school library in particular.

Read and review the relevant, related literature regularly.

Work with the North Carolina Association of School Librarians to review the issues and help plan directions, in-service training, and support.

Explore the opportunities to network on many different levels within all types of situations. Remember that networking can be a cooperative venture that may or may not involve resource exchange.

Define the local benefits and drawbacks realistically. Studies in Connecticut have shown that projected drawbacks due to lack of staff time or governance did not materialize in pilot projects. ${ }^{2}$

Be realistic about costs. For example, would system-level processing be a cost effective product of belonging to the OCLC system? Also consider grouping together all the libraries in an area for materials processing as a cost-cutting measure.

Encourage staff members to learn all they can from reading, from conference attendance, from a video course, and from on-site visits. A knowledge of AACR2, MARC format, telecommunications, and automation are all good starting points.

Long-range plans. Consider how your school library's materials and human resources can become a part of a network. Consider the collection. Is the shelflist in order? Should specific plans for weeding be detailed? Consider plans for training teachers and students in telecommunications and research using printed indexes and expanding to on-line catalog. Be aware of how any automated procedure begun now may need to interface later. For instance, include ISBN or LC numbers as reference points for matching with established data bases.

Ensure that resources chosen to be included in a statewide bibliographic data base are cataloged to the required standards. Know the standards and request that preprocessed materials purchased for the school library meet them.

Interesting ideas are being discussed about networking in North Carolina by the North Carolina Library Networking Steering Committee, by librarians, and by citizens. The day of an individual school library/media center, isolated from other school libraries and other library resources and library users, is fading.

Realistically, not every school library will join an electronic network, but varying levels of cooperation can be achieved. Networking, electronic cooperation, is working today.

Ready access to resources for the best service to the most people is a definite need. Be a part.

\section{References}

1. Barbara Froling Immroth, "The Role of the School Library Media Program in a Multitype Library Network" (Ph.D. dissertation, University of Pittsburgh, 1980).

2. Eugene A. Lynch, "A Survey of School Library Participation in Cooperative Activities in Southeastern Connecticut" (Paper presented at the Annual Convention of the Connecticut Educational Media Association, New Haven, October 29, 1981): 20. 


\title{
The Triangle Research Libraries Network
}

\author{
Joe A. Hewitt
}

The Triangle Research Libraries Network (TRLN), now entering its fifth year, has been described to professional audiences in North Carolina on a number of occasions. For that reason, one assumes that readers of North Carolina Libraries are familiar with TRLN's origins as part of the long history of cooperation among the libraries of Duke University, North Carolina State University (NCSU), and the University of North Carolina at Chapel Hill (UNC-CH). This article will focus on TRLN's concrete objectives, its current status, and plans for the future.

\section{Objectives of Project}

TRLN's immediate objective is to create a prototype, state-of-the-art, research library network consisting of linked on-line catalogs. (The on-line catalog being developed by TRLN has been named the Bibliographic Information System or BIS.) Each library will operate a BIS supporting its own data base on an in-house Tandem computer; the systems will be linked through telecommunications facilities to form a distributed network. Users at each campus of the network will have access to each catalog separately and to the combined catalogs as if they were a union catalog of the three collections.

Long-term plans include the implementation of circulation, acquisitions, and serials control subsystems to operate in an integrated way with the Bibliographic Information Systems. TRLN is not committed to developing original software for these subsystems. For each function, we will investigate availability of source code or design specifications suitable for adaptation to Tandem and BIS environments. As of this writing (February 1984), TRLN is negotiating with a consultant to conduct a study aimed at identifying circulation software potentially usable by TRLN.

Joe A. Hewitt is Associate University Librarian for Technical Services at the Davis Library, the University of North Carolina at Chapel Hill.

\section{Systems Characteristics}

In order to get an accurate perspective on TRLN systems within the broad framework of library automation, it is useful to focus on the major distinguishing features of the project, which are noted briefly below.

1. TRLN development has focused on the online catalog as the core and first module of an integrated system rather than beginning from a peripheral application such as circulation. It is expected that this approach will lead to an online catalog which is free of limitations resulting from basic design decisions oriented toward other functions. The main thrust of TRLN's original software development will continue to be the online catalog and its future enhancements. It is in this area that TRLN hopes to establish a position of leadership among research libraries.

2. TRLN systems are being designed to address the needs of research libraries with large and rapidly expanding collections, complex organizations, and demanding clienteles. TRLN systems will accommodate an organizationally complex library system with scattered specialized collections using a variety of cataloging rules and classification schemes. Thus the BIS will represent physical holdings and bibliographic relationships to a level of detail sufficient to handle research library collections. The relatively expensive Tandem computer was chosen because of its redundancy, reliability, and expandability.

3. TRLN systems are being designed to meet the unique needs of each TRLN library, but at the same time to serve as a node of a local area network which, in turn, will be capable of linking with other local networks, state and regional networks, and national bibliographic utilities.

In general, then, TRLN should be regarded as a large-scale, complex, and somewhat expensive system explicitly designed to meet the needs of research libraries. We have completed no studies to determine the minimum collection size at which a TRLN system would be cost-effective. BIS and peripheral TRLN systems must be more fully developed before such a study could be done with 
any degree of precision. TRLN staff, however, intuitively accept the figure of five hundred thousand volumes as the minimum below which a TRLN system would not be worthwhile, either for an individual library or for a group of libraries using a single TRLN system.

TRLN should also be viewed as a system designed to be a research library node in an openaccess, wide-area network providing a variety of levels and types of access to all potential users of the collections of the primary members. More on this aspect of TRLN is included below under the heading Linking and Access.

\section{Current Status}

A long-standing and sometimes overused TRLN slogan is "providing short-term benefits while working towarả long-term goals." Although abused, this phrase does tend to describe the current status of the TRLN project. TRLN has operated serviceable systems since the fall of 1980 while at the same time making considerable progress toward the development of the TRLN Bibliographic Information System.

The Archive Tape Processing System (ATS) and the Online Editing System (OES) have allowed TRLN libraries to build and maintain their bibliographic and holdings data bases for the BIS, thereby avoiding a major project at the time of implementation. Validation modules, inherent components of both the ATS and OES, provide quality control over the contents of the data bases. As of February 4, 1984, the size of the TRLN data bases aggregated to $1,047,379$ records, distributed among the TRLN libraries as in Table 1.

Other operational systems include the COM catalog production system and the report of recent acquisitions. Two TRLN COM catalogs have been produced. The latest, distributed in February 1984, consists of 657 fiche and includes author, title, and subject listings. Four-weekly lists of recently cataloged titles arranged by location and call numbers are produced and distributed to TRLN libraries, which in turn duplicate the lists and make them available to faculty, students, and staff.

The ATS, COM production system, and the recent acquisition service operate on the UNIVAC 90/80 at Administrative Data Processing at UNC$\mathrm{CH}$. (The ATS and recent acquisition service are being reprogrammed to run on the newly installed IBM 3083.) The OES, considered the predecessor of the BIS, operates on the Tandem NonStop II Computer located in the Davis Library at UNC-CH.

A great deal of effort on the part of TRLN Systems Advisory and Cataloging Policy Committees has gone into the development of functional specifications for the OES and the BIS. This work represents, we believe, one of the most thoroughly documented library systems design efforts at the functional level in existence. The results of this work are contained in a set of system design documents available from TRLN for the cost of duplication.

The BIS will be brought up in stages beginning in the summer of 1984 . The first segment, expected in July, will include author, title, and series access as well as access by various control numbers. Call number access and shelf list browsing is planned for early fall 1984; subject access by controlled subject terms is due late in the fall, followed by the development of enhanced subject access, including Boolean operators and use of a variety of delimiters for restricting retrieval sets. Detailed design of the circulation subsystem will begin in September 1984. The target date for implementing the circulation subsystem cannot be predicted until it is known whether original software must be written or already existing programming can be adapted. Preliminary investigation of potentially useful acquisitions and serials control software will also begin in the fall of 1984 .

Space does not allow a detailed description of the features of the TRLN on-line catalog. It should be noted, however, that a number of features presumed to make a system "user friendly" are planned. These include choice of guided and com-

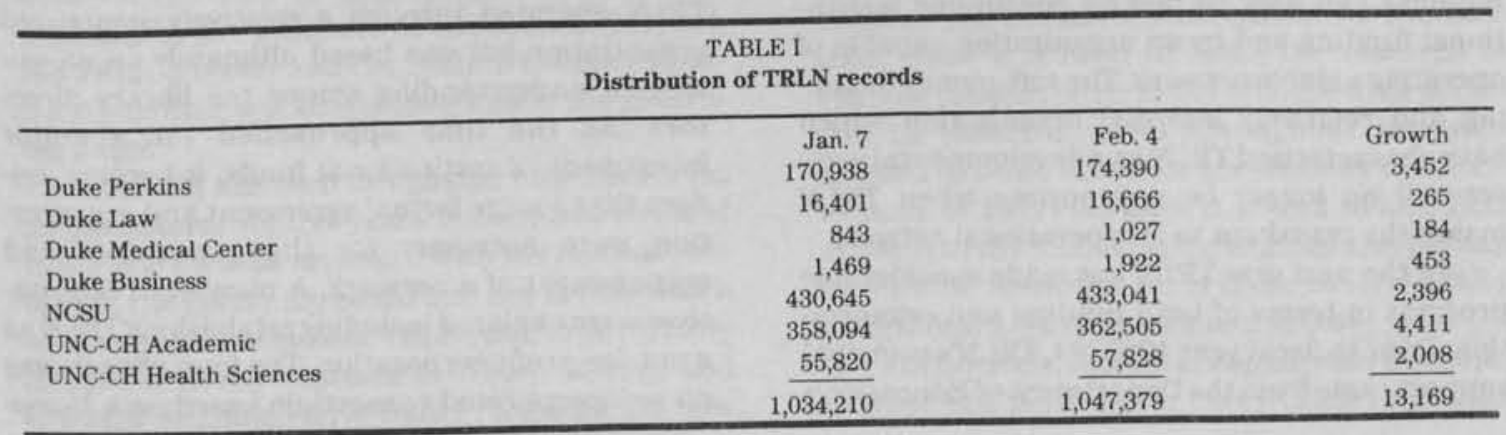


mand modes; generous use of instructional and help messages; choice of display formats; limiting of searches by date, language, etc.; searching by specific collections and collection subsets; and so on. We expect that the BIS, as an on-line catalog, will be equal to other on-line catalogs in most respects while being superior in some, which is to be expected of what is conceived as a second generation system. System deficiencies, of course, are not being planned and cannot be described in any specific way at this time.

In predicting the availability of TRLN systems, a distinction must always be made between the completion of a segment of software and the availability of sufficient hardware, particularly storage space, to actually operate the new component. This is especially the case as long as the systems for all TRLN libraries are operated on the same computer at UNC-CH. The projected dates noted above are for completing the coding of software modules and their testing on small test files. Actual implementation could be delayed, perhaps considerably, by lack of funds to acquire disk drives. Current plans call for mounting the UNC-CH data base for a full-scale field test of all BIS components while simultaneously maintaining the Duke and NCSU files on-line in BIS format for data base maintenance. Potential outside users of TRLN should be aware that the network will not be fully operational until Tandem computer systems have been installed in all TRLN libraries. Although steps are underway to acquire hardware at Duke and NCSU, the timing of the required funding is still uncertain.

\section{Organization and Financial Support}

The TRLN libraries recognize that local development of a system on the scale of the BIS involves a long-term commitment to software maintenance and enhancement. Like all such systems, the BIS will be an evolving system under constant pressure to adjust to the external networking environment, to various standards as they are developed, to new generations of computing equipment, and to the growing demands of users. This substantial commitment can only be met by continuing institutional funding and by an organization capable of operating a stable network. The soft-money financing and relatively informal organization which have characterized TRLN as a developmental project will no longer be appropriate when TRLN makes the transition to an operational network.

In the past year TRLN has made considerable progress in terms of both funding and organization. Prior to fiscal year 1983/84, TRLN's principal support came from the Department of Education's
Strengthening Research Library Resources Program (Title II-C). In 1983/84, UNC-CH Academic Affairs Library was able to include in its continuing budget the cost of two systems positions as well as funds to maintain the Tandem computer being used for development. Additional funds for computing equipment were also made available. The UNC-CH Health Affairs Library assumed the cost of one programming position. NCSU added another programming position to the staff assistant position they had been funding for some time. Duke took steps to work support for the remaining TRLN positions into its budget cycle when Title II-C support ends in October 1984. These steps, taken together, ensure the continuation of TRLN at least on the scale that it has existed in the past.

\section{In the past year TRLN has made considerable progress in terms of both funding and organization.}

TRLN's overall strategy will be for each institution to maintain its own on-line catalog while making a contribution to the central TRLN organization which will supply software maintenance and other technical support. Means to meet the second obligation are in place or planned, but major funding hurdles remain with respect to acquiring hardware at NCSU and Duke. It is expected that this funding will be acquired through special institutional allocations or through foundation grants. Administrators in TRLN libraries are optimistic about recent initiatives in both directions, but funding for all nodes of the network remains an area of uncertainty at this time.

Throughout 1983 the TRLN Organization Committee and the directors of the TRLN libraries worked on an instrument for establishing a formal TRLN organization. As a development project, TRLN operated through a relatively structured organization but one based ultimately on an unwritten understanding among the library directors. As the time approached for a major investment of institutional funds, it became evident that a more formal agreement and organization, were necessary for the governance and management of a network. A number of alternatives were explored including establishing TRLN as a not-for-profit corporation. The form chosen was an unincorporated consortium based on a Memo- 
randum of Understanding signed by the Chancellors of the three institutions, with one of the members acting as host institution and legal agent. As of February 1984, the draft Memorandum had passed review at all levels of the three universities and was being prepared for signing by the chancellors.

The Memorandum of Understanding establishes a Governing Board consisting of the chief officers of each member library, plus one university administrative officer appointed by the chancellor of each member institution. The member libraries are defined as those institutions' separately administered libraries which are members of OCLC. Thus the charter member libraries of TRLN, each with Board representation, are the Fuqua School of Business Library, Law Library, Medical Center Library, and Perkins Library at Duke; the Academic Affairs Library and Health Sciences Library at UNC-CH; and the D.H. Hill Library at NCSU. It is anticipated that the board will act by consensus, but when a position supported by consensus cannot be found, the board will vote by institution, with an unanimous vote of the three institutions required for action.

The Memorandym of Understanding also establishes the position of TRLN director to manage the network and report to the governing board. The creation of this position serves to separate TRLN management from the administration of the host library and to consolidate management responsibilities previously shared by the associate director for technical services at UNC-CH's Academic Affairs Library, the TRLN library systems analyst, and the assistant director of administrative data processing at UNC-CH.

The Memorandum continues many of the proven organizational features of TRLN. The coordinating committee will continue in its role of overseeing the design and operation of TRLN systems through a series of advisory committees made up of staff of the member libraries. The chairmanship of the coordinating committee, until now closely associated with the position of coordinator of the Title II -C projects, will be chosen annually by the members of the committee. Both the TRLN director and the chair of the coordinating committee will attend meetings of the governing board.

UNC-CH has been designated host library for an initial term of three years. Subsequent terms of three years will be arranged with the mutual consent of the governing board and the library which is willing to serve as host. TRLN staff, until recently divided between quarters at Wilson Library and UNC-CH Administrative Data Processing, are now housed in UNC-CH's new Davis Library, as is the TRLN Tandem computer. Permanent quarters for the UNC-CH node of the network (and for TRLN staff, if UNC-CH's term as host library is extended) will be constructed in Wilson Library as part of the Wilson renovation project.

Taken together, these steps to secure funding from the institutions and to establish a formal TRLN organization have placed TRLN on a foundation far sounder than that provided by soft money during the early developmental years. That financial and organizational support will allow TRLN to become a stable component in a statewide network along the lines recommended by the King Research report and now being developed by the North Carolina Network Steering Committee. Just what TRLN's role should be in such a network is subject to definition, but as the following section suggests, TRLN will provide capabilities for accessing the state's largest collections, which can only be useful in such a networking effort.

\section{Linking and Access}

TRLN has always pursued a number of goals which reflect a variety of internal and external interests. On each campus there is a need to provide access from branch libraries to the holdings of the main library, both to allow habitual users of specialized libraries to make greater use of the total resources of the institution and to allow greater coordination of collection development within each library system. There is also a need on each campus to capitalize on the widespread availability of terminals and microcomputers in departmental and faculty offices in providing access to library collections.

Among the campuses there is a need to provide mutual access to collections to support longstanding programs of coordinated collection development and to allow faculty and students to approach the three collections as a single integrated resource. Users in the Research Triangle Park, particularly at the National Humanities Center, also need improved access to the collections of the research universities. At the same time, there is a need to make the research resources concentrated in the triangle area accessible to potential users throughout the state. Related to these needs for accessibility to the collections of TRLN libraries is a need to link TRLN systems to the bibliographic utilities and perhaps to regional networks. All of these concerns fall in the general area of linking and access.

Fortunately, technical capabilities developed to meet one need will in many cases meet other 
needs. The requirement on each campus for a variety of modes of access will result in a system which is also hospitable to a wide range of access for off-campus users. TRLN systems will be able to support dial access using a variety of terminals, access through dedicated lines, and computer-tocomputer access in appropriate applications. The type of access most appropriate to outside libraries will depend on the volume and type of use. As a statewide network based on the concept of the zones of cooperation (ZOC) evolves, it is expected that TRLN can play a number of possible roles depending on the optimal configuration for any given library or group of libraries.

Several TRLN projects related to linking and access are worthy of note. Although general support from the Department of Education will end in October 1984, another grant application has been submitted that focuses on the linking aspects of the network. Initially, interlibrary access to the on-line catalogs will be through terminals located at each library connected via dedicated lines to the systems at the other libraries. A second level of access will be established with the computer-to-computer links, at which time any terminal connected to a TRLN system will have access to all Bibliographic Information Systems in the network. These methods will provide serial access only, that is, the capability of searching each data base in succession.

TRLN's ultimate objective is to provide access such that the three separate data bases can function from the user's viewpoint as a single union catalog. Meeting this objective will require a system design and software development effort of some magnitude. Design specifications will be prepared for operations such as query handling and terminal contention in the multiple data base environment and collecting and merging retrieval sets from separate data bases. Special display formats for merged retrieval sets will also be developed. The grant will also support coding and testing of linking software and partial implementation of the links. Although TRLN staff will have to complete this work in any case, the links will be available sooner if supported by Title II-C funds. It should be pointed out that until the fully transparent link is developed, outside users of TRLN may have to use separate connections to each TRLN on-line catalog.

The Council on Library Resources has included TRLN as an official observer of the Linked System Project (LSP). The LSP is a councilfunded project involving LC, RLIN, and WLN to develop standard protocols for linking bibliographic data bases. As the work progresses, the council periodically sponsors meetings of representatives of selected systems organizations to inform them of developments with the project and to encourage the adoption of the LSP protocols. TRLN is interested in the possibility of developing linkages compatible with the LSP protocol, both to promote standards in general and to increase the possibility that TRLN software can be useful to others.

For some time, TRLN has been negotiating with OCLC to undertake a collaborative effort to develop an online interface between the OCLC cataloging system and the BIS. This project has received approval by OCLC management and preliminary planning began in January 1984. When completed, such a link will represent an important step in the direction of a rational interface between OCLC and locally developed on-line systems.

These linking activities are highlighted here to emphasize TRLN's commitment to the concept of linking local systems as a means of creating wide-area networks and service areas. Linking of independent bibliographic systems is still a somewhat neglected and underdeveloped technology, and much remains to be done before flexible, affordable linking mechanisms can be used to create a statewide network. TRLN's current work related to linking represents groundwork which in time will lead to technical capabilities on our part which will allow TRLN to be an effective partner in a statewide networking effort.

\section{NCASL Conference}

The 1984 NCASL Biennial Work Conference will be held in Raleigh, October 4-5, at the Raleigh Civic Center Complex.

If any section or committee of NCLA would like to meet in Raleigh during the Work Conference, please notify Helen Tugwell, vice-chairman/ chairman elect of NCASL, immediately.

Address and telephone numbers:

Helen Tugwell

Route 6, Box 214

Wilson, NC 27893

Home: 919-243-2630

Work: 919-291-9450

The theme of this year's conference is "Library Media Services: Practical and Political." 


\title{
The North Carolina AHEC Network
}

\author{
Lynne Siemers
}

"The North Carolina Area Health Education Center (AHEC) Program is a unique partnership between the university health science center and the community ... to improve the geographic distribution of well-trained health professionals and support personnel, and to increase the supply of personnel trained to meet the primary health care needs of the people of North Carolina."

In addition to its goal of training and retraining primary health care personnel and improving the distribution of health manpower, the AHEC program is a voluntary effort to

1. Enhance the professional environment by providing opportunities for continuing education and technical assistance for all health personnel at a regional and local level. 2. Provide training opportunities in community settings for students in allied health, dentistry, medicine, nursing, pharmacy and public health.

3. Avoid duplication of training efforts by a coordinated system of university and community education networks, while enhancing regional training capabilities. ${ }^{2}$

The nine AHECs in the state are linked to a university health sciences center as well as community hospitals, other university campuses, community colleges, technical institutes, and practicing professionals in their respective regions. The program has developed under the leadership of the dean of the School of Medicine at the University of North Carolina in Chapel Hill with the cooperation of other health schools at Chapel Hill (Dentistry, Nursing, Pharmacy, Public Health), the Bowman Gray School of Medicine of Wake Forest University, the Duke University Medical Center, and the East Carolina University Health Science Schools (Medicine, Nursing, Allied Health).

\section{The History of AHEC in North Carolina}

In 1970 the Carnegie Commission on Higher Education issued a report, Higher Education and the Nation's Health. This report came at a time of concern over the shortage of health manpower; the Comprehensive Health Manpower Training Act of 1971 was strongly influenced by the report.

Lynne Siemers is AHEC Liaison Librarian at the Health Sciences Library at the University of North Carolina at Chapel Hill.
One recommendation of the Carnegie Commission called for the creation of area health education centers designed to improve the quality of health training and to overcome the geographic maldistribution of health professionals. ${ }^{3}$

At the same time, the UNC-CH School of Medicine was developing affiliations with community hospitals in the state to provide clinical training for medical students. Funds for this activity were provided by the North Carolina Regional Medical Program, the Duke Endowment, and the North Carolina General Assembly. These activities enabled the university to respond to requests for intent to develop AHEC programs from the Bureau of Health Manpower Education of the Department of Health, Education, and Welfare. Monies for these AHECs had been authorized in the 1971 Comprehensive Health Manpower Training Act.

In 1972, HEW awarded the UNC-CH School of Medicine a contract for $\$ 8.5$ million to develop three AHECs. This was one of the original eleven contracts in the country. The school received an additional $\$ 1$ million for the projects from state funds and from six community hospitals. In 1974 the North Carolina General Assembly appropriated $\$ 28.2$ million to expand the AHEC program into a statewide network with nine regional centers. Each AHEC was to include a library and audiovisual resource center.

\section{The Library and Information Services Network}

The North Carolina AHEC program marked its ten-year anniversary in 1983. An integral part of the program-some say its most visible component-has always been the library and information services network. The network itself is a statewide resource, providing access for health professionals not only to the resources of each of the thirteen present AHEC libraries but also to the health science center libraries. In addition, each AHEC library has developed its collections and services in response to the unique needs of the region's health professionals. Networking is a key component among the objectives which the libraries defined for themselves in the 1981 Standards: 
1. To provide information services to the AHEC region from the AHEC center by developing a core collection of books, audiovisual materials, and journals within the region and by providing access to the resource libraries of North Carolina and the national biomedical communication networks. 2. To develop library collections in health care facilities located in the AHEC region.

3. To provide access to audiovisual equipment and production services in support of educational activities of the AHEC region through referral or on-site facilities.

4. To disseminate information concerning AHEC and especially library learning resource center resources and services.

5. To make all types of information more available by a network of shared resources with public libraries and libraries of other health agencies, community colleges, and technical institutes. ${ }^{4}$

Perhaps one of the most telling indications of the growth of the network of AHEC libraries is the increase in professional personnel. The first AHEC librarian was hired in 1974. Ten years later, there are 17 librarians employed throughout the state.

Having realized early on the benefits of cooperation and networking, the AHEC libraries and librarians have continued to add to the list of accomplishments of the network. To date this ranges from the fifth edition of the Union List of Audiovisuals to on-line demonstrations at state meetings of health professionals.

\section{Network Products and Services}

The North Carolina AHECAudiovisual Union List is published annually. The 1983-84 edition, available in either microfiche or paper copy, lists over eight thousand unique audiovisual programs. Holdings include the four academic resource libraries and the nine AHEC libraries. Microfiche copies are distributed free to all North Carolina hospitals. Other libraries and agencies may purchase the list from the Central AHEC Office.

Other products of the AHEC network include a monthly newsletter, an annual directory of personnel, and the 1981 NC AHEC Library/LRC Standards. These standards reflect the emphasis on local development which is apparent throughout the system: “... a major strength of the AHEC program lies in the autonomy granted each regional center; [thus,] no attempt has been made to give numerical quotas in the standards statements. Rather, the focus is on stating the scope, level, and quality of service recommended; [the] guidelines are intended to assist in attaining ... standards. This is both an assessment and planning tool that will enable AHEC directors and staff to develop services cooperatively to address regional needs. ${ }^{\mathrm{5}}$

Because all AHEC libraries have access to the on-line databases of both Bibliographic Retrieval
Services, Inc., and the National Library of Medicine, it has become almost routine to plan the educational demonstrations of these on-line services at the annual meetings of physicians, nurses, pharmacists, dentists, physicians' assistants, hospital administrators, and public health personnel. A follow-up study is planned to determine what effect participation in these demonstrations has on the further use of library and information services by these health professionals.

\section{Regional Differences}

While the primary focus so far has been on the cooperative activities of the network, it is equally important to examine the difference between library and information services in each AHEC (see Figure 1). It is here that the "regional autonomy" becomes clear, since each has been developed in response to the needs of the region; in fact, some of the strengths of the network come from the local diversity represented by each AHEC.

Mountain AHEC (Asheville) serves as the library for both Memorial Mission and St. Joseph's hospitals. Located in a bridge between the two institutions, MAHEC also offers the services of its combined information/media services department to the area's health professionals and students. It is the only one of the AHECs so structured.

The seventeen counties which comprise the Northwest AHEC (Winston-Salem) have been organized into four subregions. The library and information services in each of these subregions is centered around a multitype, cost-sharing consortium. This concept was first implemented in the Hickory area with the formation of the UNIFOUR consortium. ${ }^{6}$ Boone, Winston-Salem, and Salisbury are the headquarters sites of the other consortia. In addition to hospital libraries, community colleges, mental health centers, schools of nursing, local health departments, and state institutions are members of these consortia. Services are delivered by librarians on a regular circuit to each member institution.

Development of local consortia, but on a voluntary basis, has been the route taken by the Greensboro AHEC. The Rockingham County Health Information Consortium and Randolph County Health Information Consortium, both multitype consortia, received National Library of Medicine grant funds to aid in the development of resources in individual libraries and for the support of intraconsortium activities. With the expiration of the grant funds at the end of 1983 , the members of the Rockingham Consortium have agreed to share the salary for a part-time coordinator. Another volun- 
tary consortium in Alamance County is in the organizational stage.

The Library/LRC at the Charlotte AHEC is a result of the 1976 merger of the library resources of Charlotte AHEC and the Mecklenburg County Medical Society. Library and information services in the Charlotte AHEC area as well as those in Wilmington, Eastern (based at the Health Sciences Library of ECU, Greenville) and Area L (Tarboro) are provided through a combination of circuitriding librarians and consultant contacts at community hospitals and local health agencies.

National Library of Medicine grant funds were awarded to support the development of AHECbased consortia in two regions. The Fayetteville AHEC received funds for the Cape Fear Health Sciences Information Consortium, a group of fourteen hospitals, technical institutes, public libraries, state universities, and public health agencies. The journal holdings of the consortium are included in the Cape Fear Library Association's Union List of Serials.

Most recently the Resources for Health Information (ReHI) Consortium received grant funding. The Wake AHEC (Raleigh) serves as the administrator for this consortium of fifteen institutions. Hospitals in Durham and Person counties are also members of the consortium.

\section{Network Coordination and Professional Development}

Technical assistance and consultations are provided to all AHEC libraries by the AHEC liaison librarian and the audiovisual liaison based at the UNC-CH Health Sciences Library. Through a contractual arrangement with the central AHEC office, this academic resource library provides staff and support for these positions.

As the network has evolved over the past ten years, roles played by both the academic health sciences center libraries and the AHEC libraries have changed. The Health Sciences Library at the University of North Carolina at Chapel Hill serves as the primary resource library for Mountain, Greensboro, Area L, Wake, Charlotte, and Wilmington AHECs; Northwest AHEC makes use of the Carpenter Library of the Bowman Gray School of Medicine; FAHEC's ties are to the Duke Medical Center Library; and the outreach library services of Eastern AHEC are based at the Health Sciences Library of East Carolina University in Greenville.

The dependence on the resources of these academic libraries has declined as the AHEC libraries have built their respective collections of resources and established and strengthened ties with libraries within their regions. Indeed, as the AHEC libraries themselves have identified their

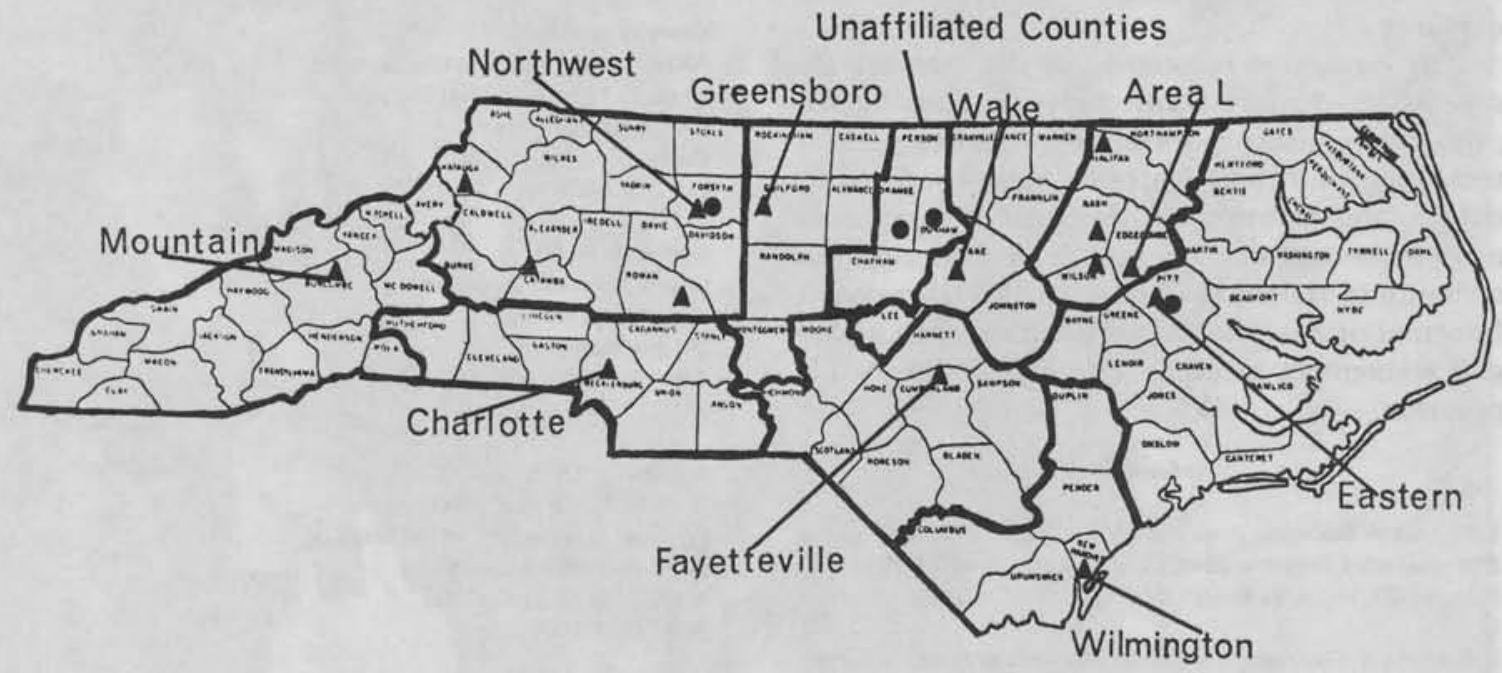

\ AHEC Library/LRC

- University Health Sciences Library 
own resources for each other, inter-AHEC borrowing and lending have increased.

Continuing education, an important component of the AHEC program, has been provided by and for AHEC librarians. In a small hospital or health agency, responsibilities for the daily operation of the library often are assigned to personnel with other unrelated duties. Many seminars are geared for these untrained hospital library managers. Seminars address subjects such as basic reference and technical services, introduction to cataloging, and interlibrary loan services. AHEC librarians have attended such courses as teaching skills for library educators, managerial writing, grantsmanship, and assertiveness training.

\section{Conclusion}

The North Carolina AHEC Program is entering its second decade with a new five year plan for 1985-1990. The Library and Information Services Network has also begun to lay groundwork for the future. In addition to supporting new AHEC programs focused on aging, health promotion/disease prevention, environmental and occupational health, and management education for health professionals, AHEC libraries are planning for the increasing use of technology. IBM XT microcomputers will be installed in 1984 in all AHEC and resource libraries. Planned network use of these machines includes preparation of updates for both the audiovisual and journal union lists, quarterly and annual statistical reports, and demonstrations. Electronic linkages for messages, bulletin boards, and interlibrary loans are also being explored.

By remaining responsive to the increasingly sophisticated information needs of regional health professionals, incorporating appropriate uses of technology for both internal and cooperative efforts, and through maintenance of a commitment to strengthening ties to the local information community, the North Carolina AHEC Library and Information Services Network will remain an integral element in meeting the goals of the AHEC program.

\section{References}

1. The North Carolina Area Health Education Center Program: Recommended Program Plan, July 1, 1980-June 30, 1985 (Chapel Hill, NC: Area Health Education Centers Program, n.d.), i.

2. Rebecca W. Davidson, The Library/Learning Resource Center Network of the North Carolina AHEC Program (Atlanta, GA; Center for Disease Control, 1981), v.

3. Charles E. Odegaard, Area Health Education Centers: the Pioneering Years, 1972-1978 (Berkeley, CA: Carnegie Council on Policy Studies in Higher Education, 1979), viii.
4. North Carolina Area Health Education Centers Library/LRC Standards, 1981 (n.p., 1981), 1.

5. Ibid., introduction.

6. Phyllis Gillikin, et al., "A Self-Supporting Library Service in a Rural Region; A New Look at Hospital Consortia,"

Bulletin of the Medical Library Association 70 (April 1982): 216-223.

\section{Appendix A \\ North Carolina \\ Area Health Education Centers \\ Libraries}

Area L AHEC

Library/Information Services

Health Education Foundation of Eastern North Carolina, Inc. P.O. Drawer 1319

Tarboro, NC 27886

919-823-1353

Charlotte AHEC

Medical Library of Mecklenburg County/Learning Resource

Center of Charlotte AHEC

P.O. Box 32861

Charlotte, NC 28232

704-331-3129

\section{Eastern AHEC}

Outreach Library Services

Health Sciences Library

East Carolina University

Greenville, NC 27834

919-757-2242

\section{Fayetteville AHEC}

Library/Information Services

FAHEC

1601-B Owen Drive

Fayetteville, NC 28304

919-323-1152

\section{Greensboro AHEC}

AHEC Library/Information Services

Moses H. Cone Memorial Hospital

1200 North Elm Street

Greensboro, NC 27420

919-379-4483

\section{Mountain AHEC}

Information and Media Services

Mountain AHEC

501 Biltmore Ave.

Asheville, NC 28801

704-258-0881

Northwest AHEC

Area IV, Northwest AHEC

Bowman Gray School of Medicine

300 South Hawthorne Road

Winston-Salem, NC 27103

919-748-2008

Northwest AHEC Library

Catawba Memorial Hospital

Fairgrove Church Road

Hickory,NC 28601

704-322-0662 
Northwest AHEC Library

Rowan Memorial Hospital

612 Mocksville Ave.

Salisbury, NC 28144

704-638-1081

Northwest AHEC Library

Watauga County Hospital

Deerfield Road

Boone, NC 28607

704-264-2431

\section{Wake AHEC}

Medical Library

Wake County Medical Center

3000 New Bern Ave.

Raleigh,NC 27610

919-755-8529

\section{Wilmington AHEC}

Medical Library

New Hanover Memorial Hospital

2131 S. 17th Street

Wilmington, NC 28402-9990

919-343-0161
University Health Sciences Center Libraries

Coy C. Carpenter Library

Bowman Gray School of Medicine

300 South Hawthorne Road

Winston-Salem, NC 27103

919-748-4691

Medical Center Library

Duke University

Durham, NC 27710

919-684-2011

Health Sciences Library

East Carolina University

Greenville, NC 27834

919-757-2212

Health Sciences Library

University of North Carolina at Chapel Hill

Chapel Hill, NC 27514

919-966-2111

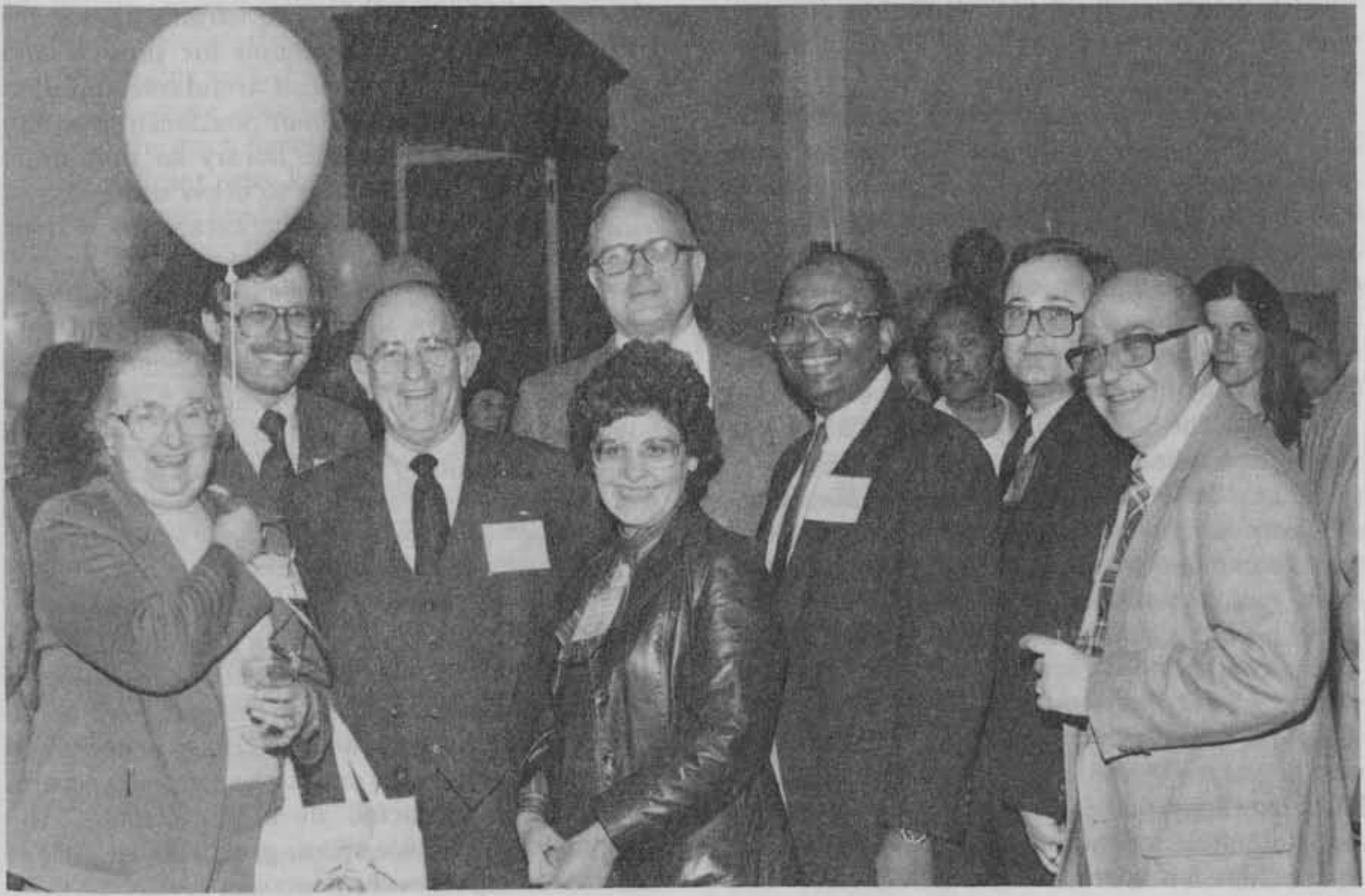

NCLA delegation to ALA Legislative Day in Washington: ( 1 to $r$ ) Louise Boone, Jerry Thrasher, J. A. Killian, William Bridgman, Artemis Kares, Dr. Benjamin Speller, Henry Hall, and Arial Stephens. The delegation visited Congressmen Ike Andrews, Stephen Neal, Tim Valentine, Robin Britt, and Jim Martin. 


\title{
The Walter R. Davis Library
}

\author{
Larry Alford
}

On the night of February 6,1984 , temperatures dropped to the low teens. That night two University of North Carolina at Chapel Hill undergraduates, Allen Ashcroft and Scott Jones, camped at the front door of the Walter R. Davis Library so they could be the first to enter the building when it opened at 8:00 the next morning. The official opening of the Davis Library on February 7,1984 , was the culmination of more than four years of construction and over eleven years of planning.

The construction of the Davis Library was the second step in a three-step plan to improve library facilities at the university. That plan, approved in the early 1970 s under the leadership of then Chancellor N. Ferebee Taylor, called for construction of a three-floor addition to the Health Sciences Library, construction of a new central library, and the renovation of Wilson Library for special collections.

Money for this construction came from the sale of the university-owned utilities in Chapel Hill. Legislative approval to use the proceeds of the utility sale for library construction was obtained through the efforts of many individuals, led by Chancellor Taylor and former Chairman of the UNC-CH Board of Trustees, Walter R. Davis. The new central library was named for Mr. Davis, who is a major benefactor of the university and a member of the Board of Governors of The University of North Carolina.

The Walter R. Davis Library replaces the Louis Round Wilson Library as the central library on the campus at UNC-CH. The Wilson Library, with major additions in 1952 and 1977, has served as the central library at UNC-CH since 1929. After extensive restoration and renovation, Wilson Library will house the Rare Book, North Carolina, Manuscript, and Map Collections. Wilson Library will also be used to store important but lesser-used materials from all of the libraries on the university campus. There will be storage space there for more than one million volumes.

Larry Alford is Circulation Librarian at the Davis Library at the University of North Carolina at Chapel Hill
Planning for the new central library began under the direction of Dr. James F. Govan, university librarian, in 1973. With the guidance of the University Planning Office, Dr. Govan and the library staff prepared a building program describing the requirements for the new library. Central to the program statement was the requirement that the primary public service functions of reference, circulation, the public catalog, and current serials be located on the first floor within view of the building entrance. Other requirements included making the building accessible to the handicapped; centralizing the collection development, acquisitions, and cataloging functions on the ground floor to make processing of materials more efficient; and providing sufficient shelf space for the growth of the library's collections through at least 1995. The various operations of the library were analyzed for present and future space requirements. Careful consideration was given to the functional relationships of the various units within the library so that units would be physically close to other units, to the book stacks, and to the public catalog when their functions required such proximity.

Two award-winning architectural firms were selected by the Board of Trustees to design the building. The principal firm was Leslie N. Boney Architect of Wilmington, headed by Leslie N. Boney, Jr. Consulting with the Boney firm was Mitchel Giurgola of New York, one of the founders of the post-modernist movement in architecture and one of the best known contemporary architects.

Mr. Giurgola and Mr. Boney attempted to relate the Davis Library to its surroundings and to keep the massive building from overpowering the surrounding campus. On the north side of the site are several dormitory buildings constructed during the late 1920 s and to the south are several buildings constructed during the $1960 \mathrm{~s}$. The architecture of these buildings reflects the style of the time they were constructed.

Several design features were used to relate the library to surrounding structures and to reduce the apparent size of the building. The 


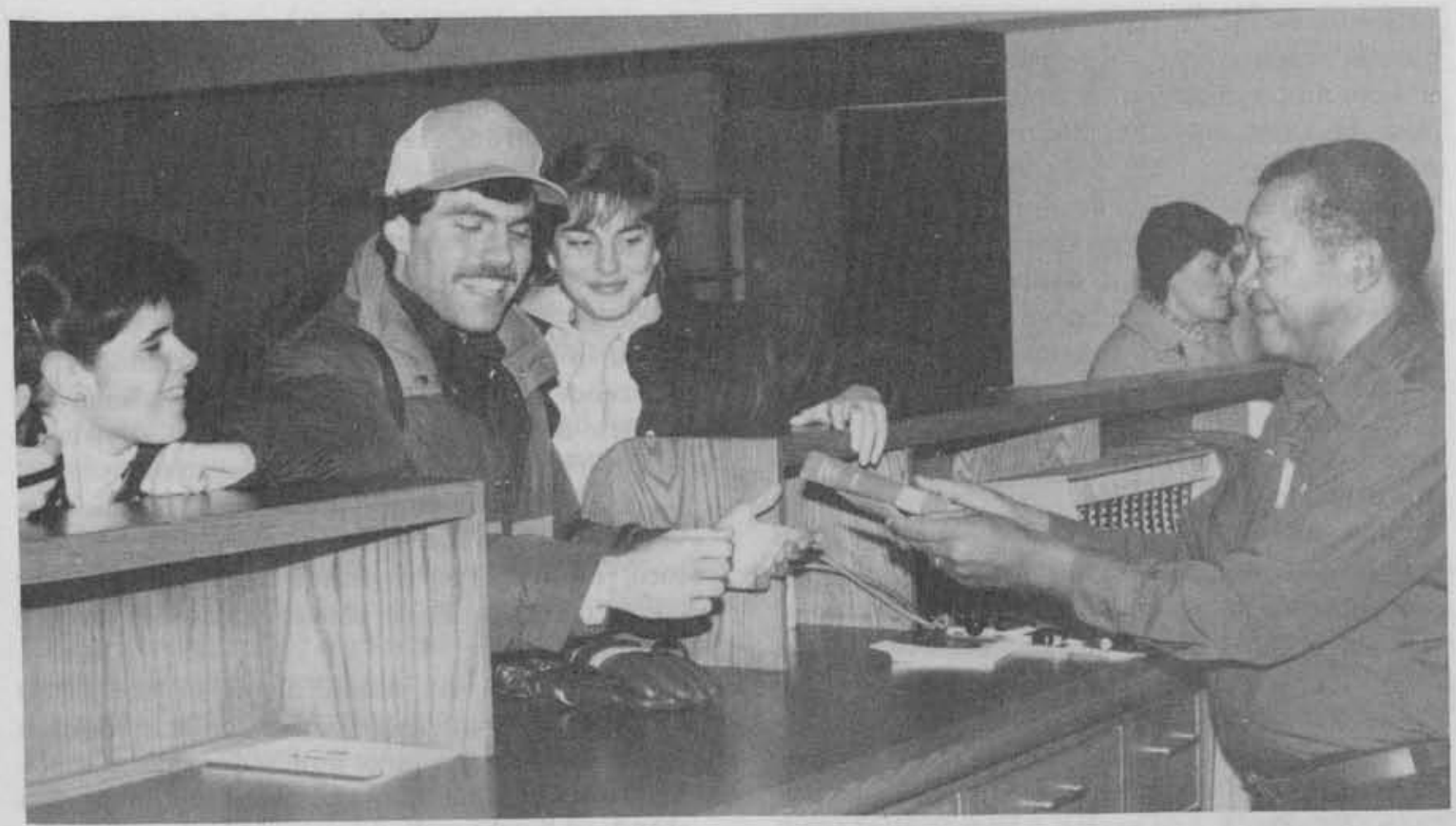

On opening day, library staff member Clifton Jones checks out the first book, George Orwell's 1984, to UNC-CH undergraduate Allen Ashcroft. (Photo by UNC Library Photographic Service.)

library was placed close to the modern buildings on the south side, thereby creating an urban setting in keeping with the character of those buildings. Limestone was used to provide a visual break in the brick facade. The eight-story portion of the building was located on the south side. Limestone was used to create three architectural units from the six upper floors. On the north side, a low, sloping roof with dormer windows and slate trim was used to relate to the traditional buildings. Finally, angles, breaks in the walls, and towers were used to decrease further the visible mass of the building.

The Davis Library is indeed massive. It contains approximately 422,659 square feet, or almost ten acres of floor space. Of that, 277,836 square feet is assignable space. The building and its furnishings cost $\$ 22.4$ million dollars. Davis is designed to hold 1.8 million volumes plus a large microform and government documents collection. Seating is available for over three thousand users.

\section{First Floor}

In accordance with the design goals described above, the Circulation Department, the Current Serials and Newspapers Reading Room, the two reference departments, and the public catalog are located on the first floor within view of the public entrance. All of these units open onto a large central gallery which serves as both an architectural focal point and as a major traffic corridor.

The gallery is three floors high, 25 feet wide, and more than 270 feet in length. Balconies on both the second and third floors open onto the gallery, adding to the openness of the building. Large, colorful banners hung from the ceilings were used to decorate the gallery. These banners, designed specifically for the gallery, depict printer's marks taken from some of the books in the library's Rare Book Collection.

Providing an open, light, and spacious quality in the public areas was one of the major building design criteria. To that end, few interior walls are used in the public areas. Where possible, windows permit natural light to enter the building, creating an open and pleasant atmosphere. Unfortunately, that same openness has led to some complaints about noise, particularly in the areas near the gallery. To accommodate unanticipated organizational or service changes, almost all of the internal walls are non-load-bearing. Thus, all of the building space, public and staff, is flexible and can be easily altered.

One other major architectural feature of Davis is the large reading room on the north side of the building. That room, which houses both 
reference departments, features a thirty-two-foot vaulted ceiling with large vaulted windows at either end. Skylights and dormer windows permit abundant natural light to enter the room. Many of the University's alumni associate the library with the ornate and beautiful reading room on the second floor of Wilson Library. The new reading room in Davis is a deliberate attempt to suggest that room in a modern context.

The location of the major service units on the same floor and within sight of each other and the placement of the two reference units in the same room, have made referral must easier. Staff are more willing to refer patrons to another unit, because directions are easy to give and they can see the patron go to the other unit and receive help. Patrons are more willing to cross a room or to cross the gallery for help than to go to another room or floor.

The library's technical services departments are also located on the first floor. Those departments include Collection Development, Acquisitions, Cataloging, and Serials. The technical servi- ces departments occupy a large room ( 80 feet by 210 feet) and adjacent office space. The large room is intended to make the flow of library materials through technical processing more efficient. Shelving and movable office panels have been used to break up the space and to provide some privacy.

In anticipation of increasing automation in libraries, an extensive duct system has been provided in the technical services area and in the reference room so that communication lines and electric outlets can be located almost anywhere. In addition, a telephone conduit system intended to accommodate communication lines was provided throughout the entire building. It is, therefore, relatively easy to provide telephone or other communication lines almost anywhere in the building.

There are six stack floors in the Davis Library. The main library collection is shelved on those floors near a large number of reader seats. To make the stack floors pleasant and inviting, a standard height ceiling was used rather than the

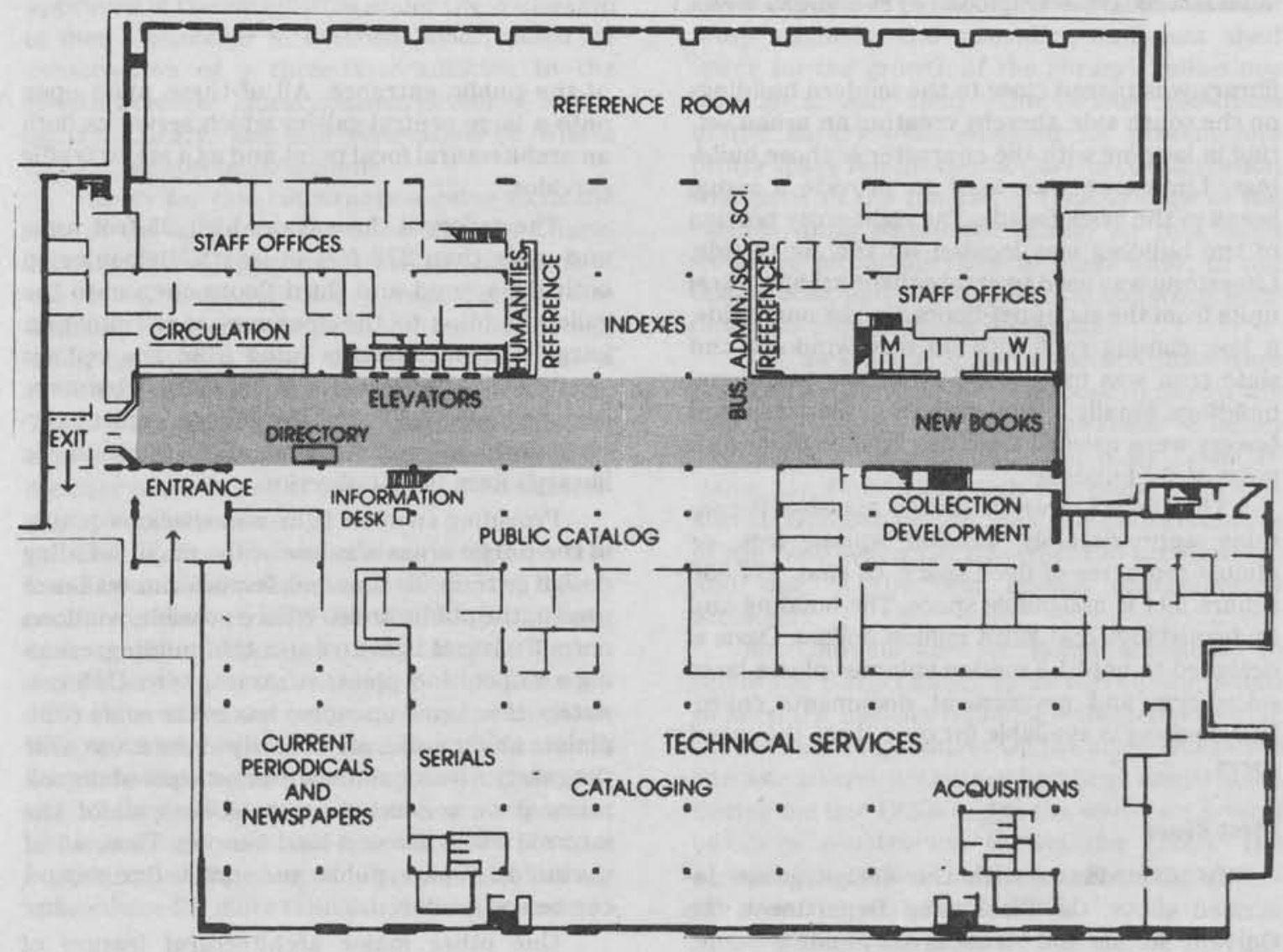

Map of the first floor of Davis Library.

80-North Carolina Libraries 
low ceilings often found in the stacks of large research libraries. As noted earlier, as much natural light as possible has been provided. The artificial lighting is mostly indirect to minimize glare. To help reduce energy costs, the level of lighting necessary to each space was studied carefully, and the lowest acceptable level of lighting was used. The shelves, ceilings, floors, and walls are off-white in color to reflect light. Where necessary, individual task lighting is used to supplement the general lighting.

A rectangular floor design was used for the stack areas to permit a logical arrangement of shelving and the classification sequence. Wilson Library was built in successive stages and included a large number of alcoves which created very unusual shelving sequences. Patrons in Wilson Library frequently requested assistance from staff in locating a particular call number. Such a request is a rare occurrence in the Davis Library due to the logical, rectangular layout of the stacks.

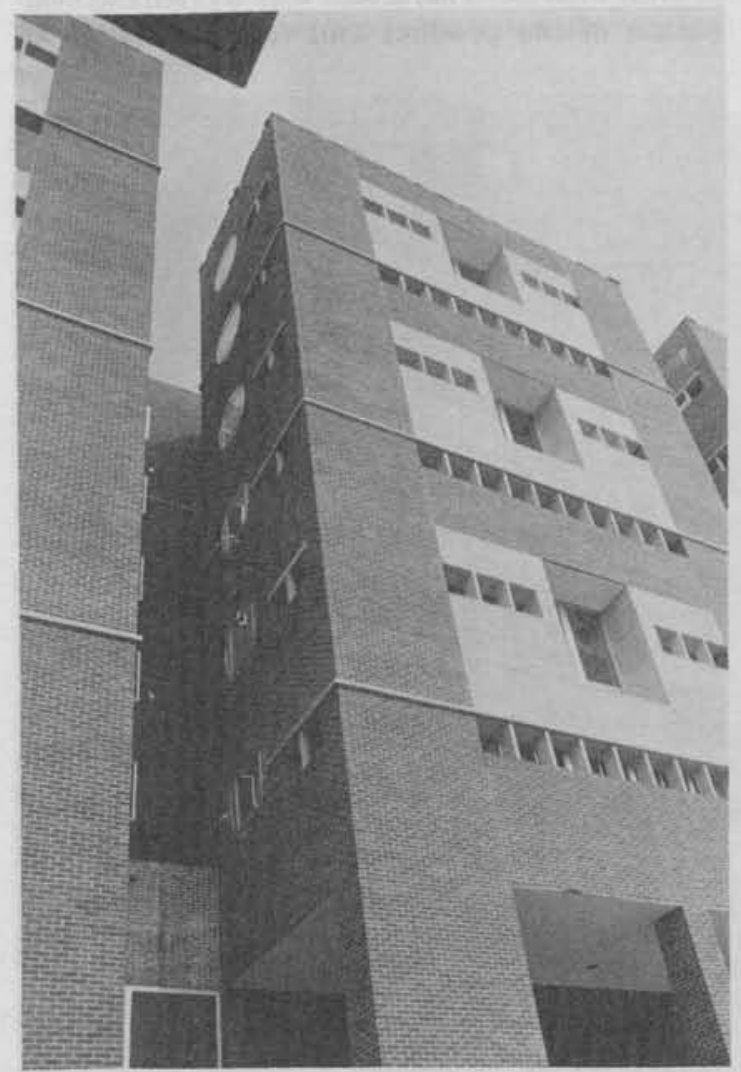

One of the six towers on the south side of the building. The closed graduate student studies are housed in these towers. (Photo by UNC Library Photographic Service.)

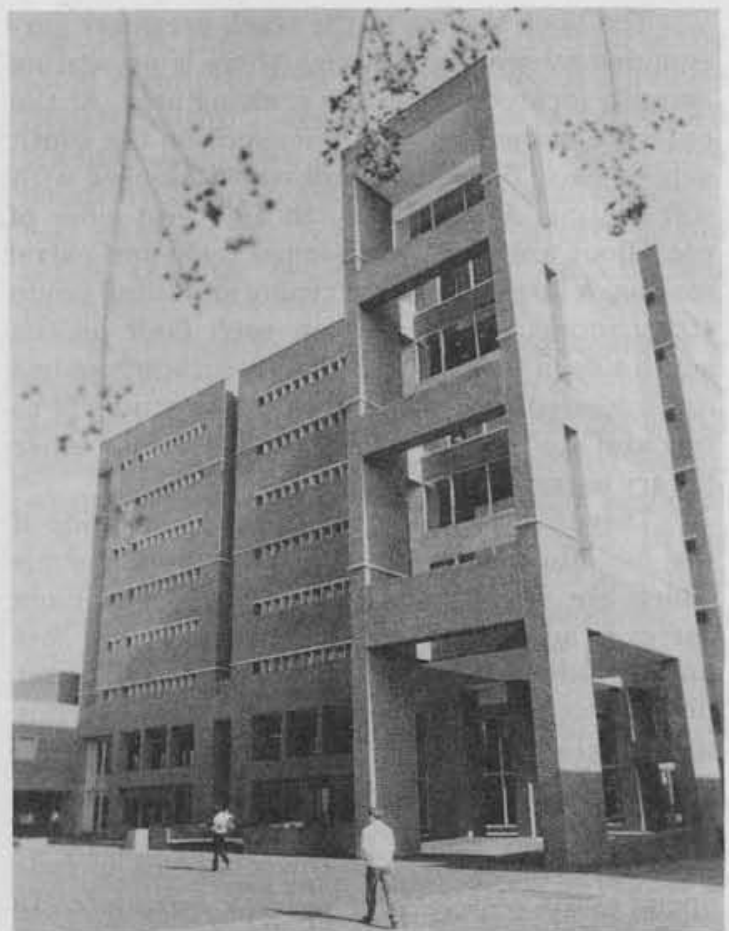

A view of the west end of the Davis Library. The entrance to the building is located at the far left under the arcade. (Photo by Will Owens, UNC News Bureau.)

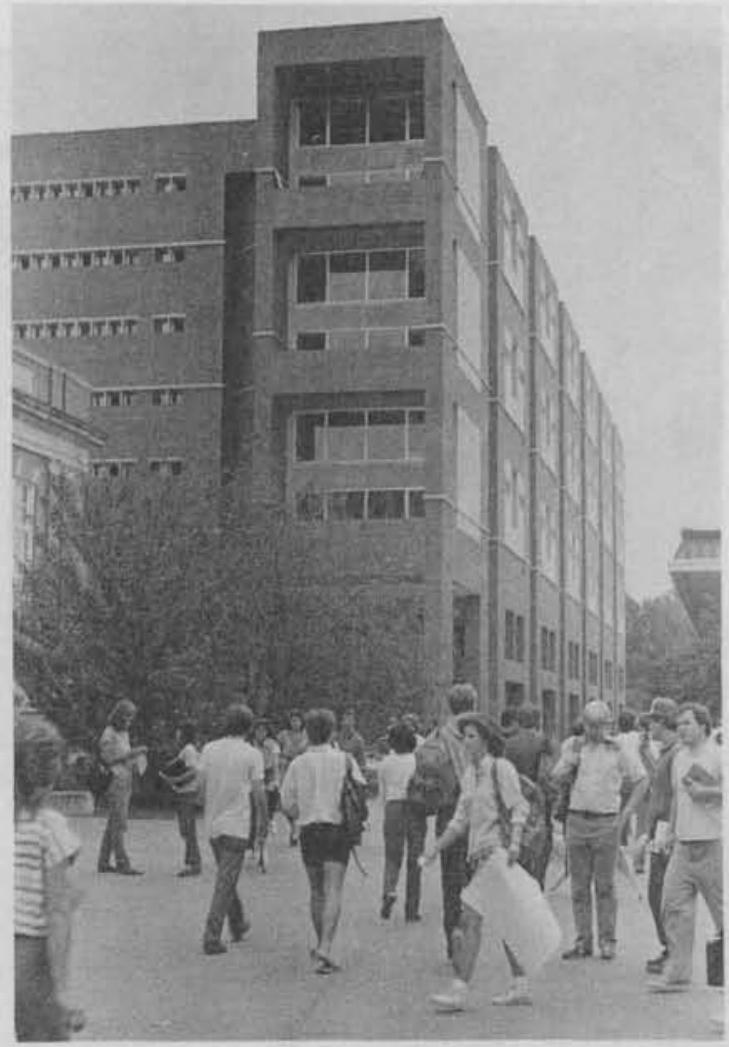

The southwest corner of the library. (Photo by UNC Library Photographic Service.) 
The book shelves in the stack areas are surrounded by seating although there is no seating actually located within the shelving area. At the opposite corners of each floor and on the south side of each floor are comfortable lounges with soft seating. Along the north and west sides of each floor are open, unassigned table and carrel seating. A large number of typing and small group study rooms are located on each floor on the south side of the building. The group study rooms are intended to provide a place for students to talk and study together without disturbing other library users.

There are also six towers on the south side of the building which provide 492 closed carrels which are assigned to graduate students. Each carrel is approximately twenty-five square feet and includes a desk and bookshelves. The tower design was used to extend the available exterior wall space of the building with a minimum increase in square footage. Because of the increase in perimeter space, each closed carrel has an exterior window. The tower lobbies include open carrels with lockers, also for assignment to graduate students. Finally 138 closed faculty studies, each with a window, are located at the east end of the building.

\section{Equipment and Furniture}

Library staff worked closely with the University's Interior Design and Purchasing Department as well as with the State Department of Purchase and Contract in the selection and procurement of equipment and furniture for the Davis Library. More than $\$ 2,000,000$ worth of equipment was purchased.

The single most costly equipment item was steel shelving, costing more than $\$ 1,000,000$. The shelving installation seemed so complex that a decision was made early in the procurement process to divide the purchase into several contracts. Eventually, bids were sought for four different installations. Three different manufacturers were awarded contracts. Although the decision to separate the shelving contracts did make the initial procurement process much easier, it also complicated the final installation. Library staff had to schedule, coordinate, and supervise the activities of three different installers. Further, since the shelves of one manufacturer will not fit the frames of another, extra shelves must be stored separately. However, we are now able to provide interested librarians with a firsthand evaluation of the product and the installation of

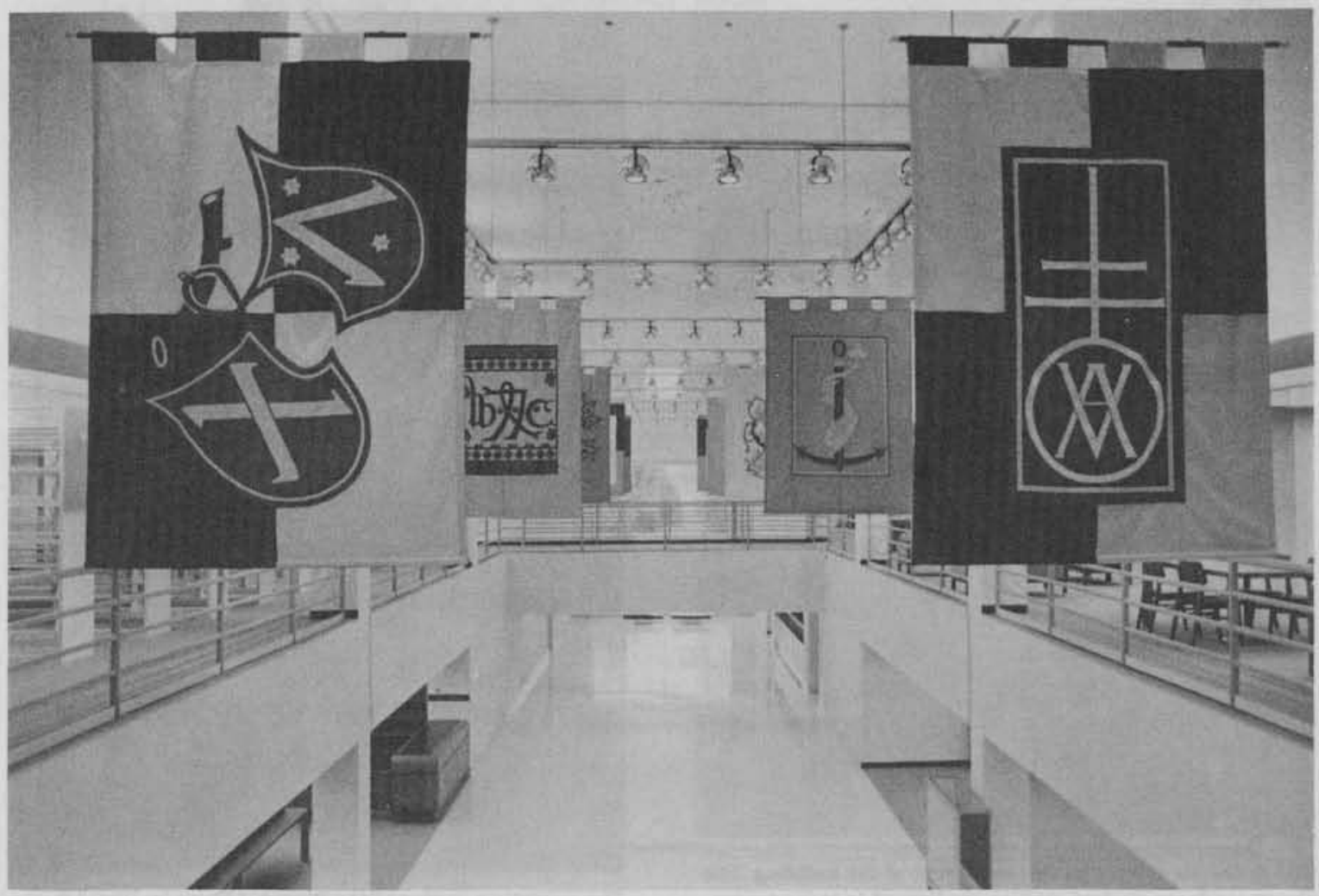

Banners depicting printers' marks hanging from the ceiling of the gallery. (Photo by Will Owens, UNC News Bureau.) 
three of the leading manufacturers of steel library shelving.

Most of the office and lounge furniture was purchased from lists of furniture available "on contract" through the State Department of Purchase and Contract. We were particularly interested in providing a variety of lounge seating so that patrons would be able to find comfortable seating according to their personal preferences. More than five hundred lounge seats were purchased, with many different styles, fabrics, and colors. For aesthetic reasons, the library staff agreed to the purchase of some sofas for the stack lounges. However, as we predicted, those sofas are usually occupied by one individual, often for napping rather than study. As the sofas wear out over the years, we will take the more practical approach and replace them with single lounge chairs.

As indicated above, both table and carrel seating were provided throughout the stacks. We were very concerned with durability of the furniture since there is very little money available for furniture replacement or repair. Because of the large number of tables and carrels needed (280 tables and 753 carrels), we were able to specify very pre-

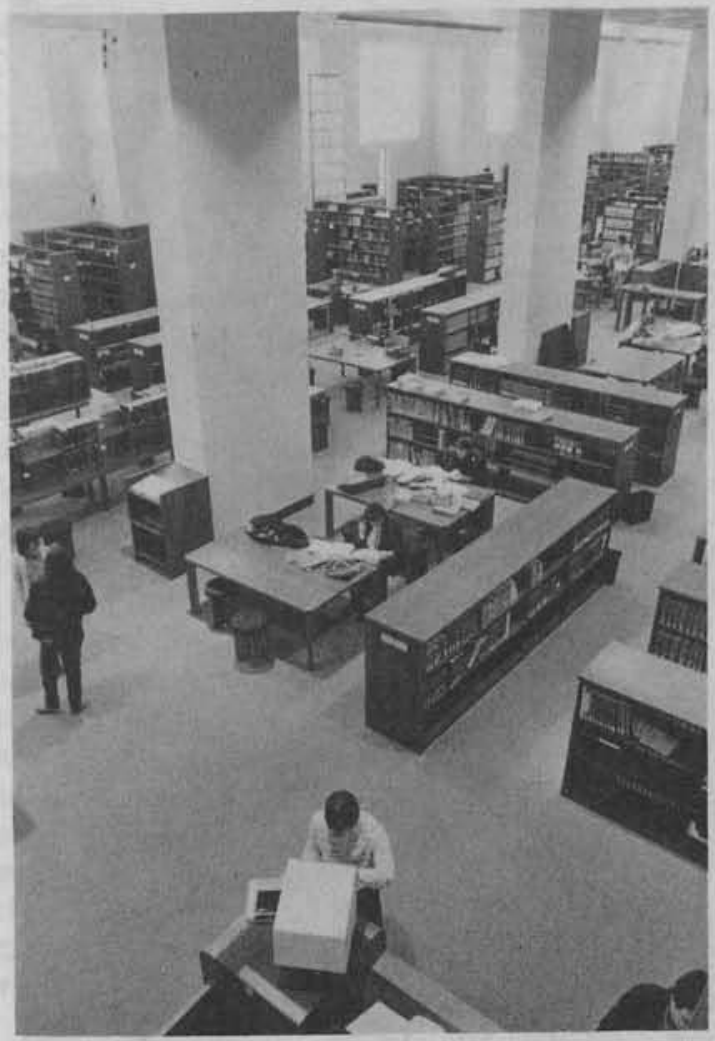

The index area in the reference room. (Photo by Will Owens, UNC News Bureau.) cisely both the style and the construction of the wood furniture. With the assistance of the State Department of Purchase and Contract, detailed specifications were prepared. A North Carolina company, Blanton and Moore of Barium Springs, was awarded the contract for the carrels and tables and, we believe, provided an excellent product.

Most of the reading chairs in the building are wood. More than 2600 reading chairs were needed, and we decided that the library could not afford maintenance on that many upholstered chairs. Again, we specified a particular design and construction. Another North Carolina firm, Boling Chair Company of Siler City, was able to produce a chair in accordance with the specifications. We believe the carrels, tables, and wood chairs are comfortable to use. We also believe the chairs, tables, and carrels will last well into the next century.

Inevitably, in a project of this size, there are problems. Invariably, furniture and equipment installations took longer than either the vendor or the library staff estimated. We have experienced the usual new building heating and cooling problems. Davis includes a number of alarm systems to

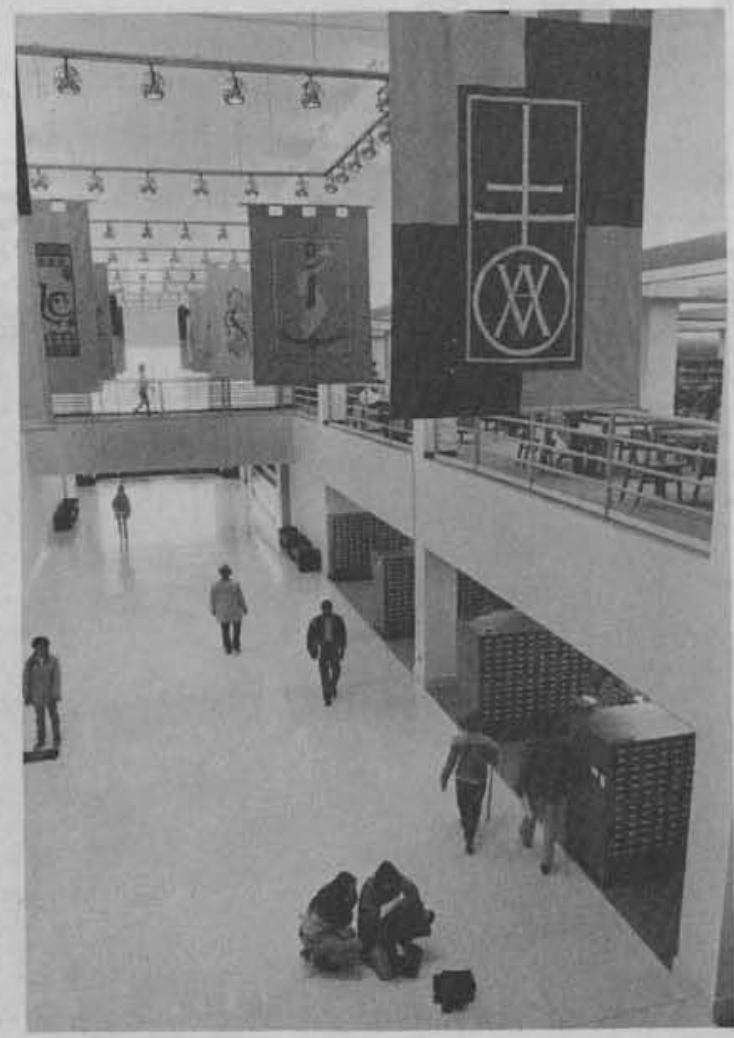

The main gallery with a view of the second floor balcony and the banners. (Photo by Will Owens, UNC News Bureau.) 
improve security, and it has taken some time for staff and patrons to adjust to those systems. We discovered during the shelving installation that some of the shelving simply would not fit as planned, and we had to revise extensively some of the shelving layouts. There were construction delays and accidents. At one point, the building was damaged when a large crane fell on it. Construction delays forced delays in the delivery of furniture, and arrangements had to be made to store furniture and shelving that could not be delivered.

Despite the problems, we believe that the Davis Library has been a great success. Perhaps the best evidence of that success is the tremendous increase in use of the facility when compared with Wilson Library. Based on the number of recorded exits, we estimate that the use of Davis Library has increased by more than 100 percent compared to Wilson Library. Between February 7 and May 1, 1984, almost five hundred thousand people used the Davis Library. While firm figures are not yet available, it appears that circulation, reference transactions, and other indicators of library use will increase significantly. Certainly, the demand for assignment to the graduate and faculty studies has far exceeded our expectations.

The university librarian, James F. Govan, accurately predicted in 1978 , while the building was still in the planning stage, that "it certainly will be more convenient for the community to use than is Wilson Library, it will be adaptable within reasonable limits to future changes, and it will be able to serve from the time of its opening as an information clearing house." Clearly, Davis Library accomplishes those goals and much more.

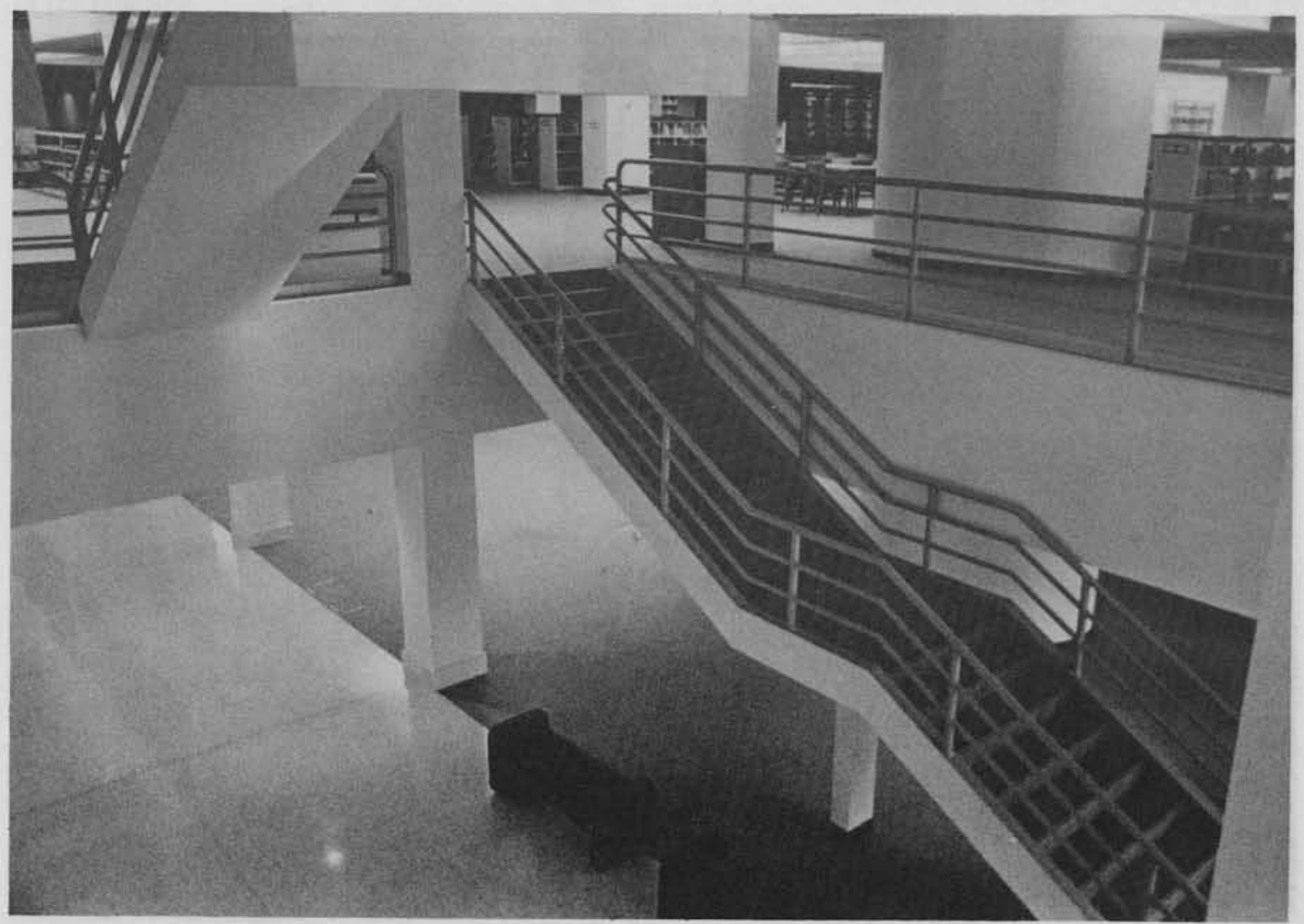

The main stair leading from the gallery near the main entrance to the second floor. (Photo by Will Owens, UNC News Bureau.) 


\title{
New North Carolina Books
}

\author{
Alice R. Cotten, Compiler
}

Vernon H. Crow. Storm in the Mountains: Thomas' Confederate Legion of Cherokee Indians and Mountaineers. Cherokee: Press of the Museum of the Cherokee Indian, 1982.275 pp. $\$ 14.95$.

Until recently, the strange and chaotic nature of the Civil War in western North Carolina has been largely overlooked by historians. But two books published in 1982 have done much to fill that gap. One is Phillip Shaw Paludan's Victims: A True Story of the Civil War (Knoxville: University of Tennessee Press, 1982), a fascinating account of the massacre of thirteen Madison County men and boys suspected of Unionist activity by local Confederate soldiers. The other is Vernon H. Crow's Storm in the Mountains, which examines the military struggle in the region by tracing the course of Thomas' Legion, one of the Confederate Army's most unusual fighting units.

William Holland Thomas was a prominent businessman and legislator from Haywood (and later Cherokee) County, but he was most noted as the government agent for those Cherokee Indians who remained in the Smokies after the 1838 removal of most of the tribe to Oklahoma. To him the mountains of western North Carolina and eastern Tennessee were "the heart of the South," and with the outbreak of war in 1861, he saw the defense of this region as the key to keeping the federal armies of the western and eastern theaters divided. To guard "the back door of Virginia" from Union invaders, he organized his own legion (a unit of infantry, artillery, and cavalry, all serving under a single commander). Consisting of mountaineers from the southwestern corner of the state and Indians recruited by their "white chief," the legion was unique not only in its makeup. It also had the distinction of being the only such unit to remain intact throughout the war, and it was the last to lay down its arms, surrendering only after a daring skirmish against federal troops near Waynesville a month after Lee's surrender to Grant at Appomattox.

This was only the final of a variety of military encounters in which all or part of the legion participated. Thomas's men fought against the for- midable combination of federal troops and proUnion residents in East Tennessee and suffered heavy losses in the Shenandoah Valley campaign under General Jubal Early in 1864. In North Carolina's mountain counties, they served as much as a police force which had to deal with bushwhackers, deserters, mob violence, and criminal activity as they did as a military force which tried to defend the area against destructive Union raids led by Colonel George W. Kirk and General George Stoneman. Thomas himself was forced to spend much of the war in Raleigh and Richmond, convincing Confederate authorities to overturn his court martial for accepting deserters into his command rather than arresting them, and to allow his legion to remain intact and close to home.

Vernon Crow, a California businessman, spent over ten years researching his subject, and the thoroughness of his narrative and its documentation is impressive. But despite the detail with which he has reconstructed the military exploits of the legion and its leaders, he has provided only the bare bones of some of the more intriguing aspects of their experience. Despite constant references to the very "uncivil" war waged in western North Carolina, Crow never really analyzes the reasons behind the divisiveness and resentment that caused such internal tensions there. Many questions regarding the nature of the Indians' role are also left unanswered. How did they fight? How did they interact with the white soldiers and civilians with whom the war threw them into close contact? And perhaps most important, why did they fight for the Confederacy for as long as they did? Other than noting their personal loyalty to Thomas and his futile efforts to curb their urge to take Yankee scalps, Crow makes little effort to explore their motives or their methods in waging a war that was not their own.

Still, Storm in the Mountains is a significant and very readable contribution to Confederate military history and to the history of western North Carolina. The narrative is greatly enhanced by a generous selection of photographs and 
charts and extensive appendixes of company rosters. Particularly worthy of note are the useful and attractive maps designed by artist William B. Secrest. As a scholarly work with much to interest more general readers as well, the book would be a valuable addition to high school, college, and public libraries across North Carolina and should be an essential one to libraries in the western part of the state.

John C. Inscoe, University of North Carolina at Chapel Hill

Heather Ross Miller. Adam's First Wife. Davidson, North Carolina, Briarpatch Press, 1983.24 pp. $\$ 2.00$ paper.

Heather Ross Miller is one of North Carolina's most distinguished contemporary writers of poetry and fiction. For her first novel, The Edge of the Woods (1964), she received the National Association of Independent Schools Award. Another novel, Tenants of the House (1966), won the Sir Walter Raleigh Prize for Fiction. And her first collection of poetry, The Wind Southerly (1968), gained her the Oscar Arnold Young Cup. She spent a year (1979-80) in England as a participant in the United States-United Kingdom Exchange Fellowship Program sponsored by the National Endowment for the Arts. In 1983 she received the North Carolina Award for literature.

Miller is a native of Badin, North Carolina, and a 1961 graduate of the University of North Carolina at Greensboro, where she studied with poet Randall Jarrell. She has taught English and writing at Southeastern Community College in Elizabethtown, N.C., at Stanly Technical Institute in Albemarle, and at Pfeiffer College in Misenheimer. Currently she is finishing a year as poet-inresidence at the University of Arkansas.

Adam's First Wife, a collection of twelve poems, is Miller's latest book. Like many of her earlier works, these poems are laden with Biblical and mythological references and, consequently, are not immediately accessible to the reader. But reading them is worth the effort, because Miller is a consummate stylist; and her choice of images and allusions is not haphazard. Rereading them reveals, as it does with all good poetry, many levels of meaning and experience.

"Adam's First Wife" is also the title of the lead poem in this collection. It is about Lilith, who, according to medieval Jewish folklore, was the wife of Adam before the creation of Eve. In folklore, generally, she was a witch believed to menace children. In these poems Lilith seems to emerge as the symbol of the pre-Biblical world, a now lost world where death was not a threat and redemption not a necessity.

In other poems here, Miller explores the theme of life and death. Life, she seems to say, is the process of death, which we cannot transcend and which our children repeat. In "Easter Stone" she writes, "I yearn at the empty stone,/ . . . / dreaming children to gleam gold beacons/ against my losing,/ darkening life." Throughout the poems, there are images of light and dark and of sleep and dreaming.

Perhaps the most striking poems in the collection are two which suggest the passing of a family matriarch, "Nell Leopard's Dying" and "Nell Leopard's Burying." In the first of these, Miller refers to Nell Leopard as "Adam's first wife," intimating that somehow Nell has transcended life and death. In the second poem she writes, "Nell Leopard will not be buried/ lying low along Rocky River./ Water rises./ She wants high ground, / ... So, when God's rocks thrust fire,/ dryhard, you'll know Nell Leopard is risen,/ that high ground is no prison."

As the first title in the Briarpatch Chapbooks, Adam's First Wife continues an association with small press publishing in North Carolina which Miller began in the late sixties when her works appeared in The Red Clay Reader. This volume is certainly appropriate for college and university libraries though perhaps not as suitable for high school or public libraries.

Susan Ballinger, University of North Carolina at Chapel Hill

Maud Thomas. Away Down Home: A History of Robeson County, North Carolina. N.p.: The author, 1982. 277 pp. $\$ 22.95$. (Order from Historic Robesoh. P.O. Box 1123, Lumberton 28358)

The title of this book gives a clue to the tone that readers will discover within its covers. Maud Thomas, an amateur historian, utilizes a folksy, "down home" style as she weaves an impressive variety of primary and secondary sources with a rambling narrative about a county that has been neglected by historians. Although several flaws detract from the book's usefulness, Away Down Home contains a wealth of information spanning the period between the $1580 \mathrm{~s}$ and World War II.

The book will please Robesonians who thirst for information about their county and its small towns. Thomas's painstaking research emerges in the footnotes that line the bottom of nearly every page. An extensive bibliography reveals the 
author's reliance on manuscript material, public documents, newspapers, interviews, and scores of books, articles, and pamphlets. Thomas discusses theories concerning the origin of Robeson's Lumbee Indians, the significant role of Scottish immigrants, exploits of the infamous Henry Berry Lowry gang, and economic, political, social, and religious aspects of important eras. The reader discovers the existence of Dr. Hector McLean's Edenborough Medical College and numerous facts pertaining to "Scalpels, Scholars, Scriptures, and Scruples," which are collected in chapter sixteen.

Yet, several flaws detract from the book's usefulness and readability. Its poor organization is exacerbated by the lack of an index. More than a few typographical errors testify to careless editing. Long quotes and extensive lists of relatively unimportant details hamper the reader's progress. The absence of photographs contributes to the book's dullness.

The facts contained in Away Down Home will be helpful to patient patrons of libraries that maintain collections of North Caroliniana. Public and school libraries in the southeastern section of the state probablyswill find the book useful, too.

Maurice C. York, Greenville

Joe M. Hatley and Linda B. Huffman, eds. Letters of William F. Wagner, Confederate Soldier. Wendell: Broadfoot's Bookmark, 1983. 103 pp. $\$ 15.00$. T.H. Pearce and Selby A. Daniels, eds. Diary of Captain Henry A. Chambers. Wendell: Broadfoot's Bookmark, 1983. 290 pp. $\$ 25.00$. (Rt. 3, Box 318, Wendell, NC 27591).

Broadfoot's Bookmark has long specialized in the publication of Civil War primary sources relating to North Carolina. Enthusiasts will welcome these two most recent volumes, which illustrate the rich diversity of material now being made available for the first time.

William F. Wagner, a Catawba County farmer, was typical of the "plain folk" of the Old South who made up the bulk of the Confederate army. He enlisted as a private in Company $\mathrm{E}$ of the 57 th North Carolina in July 1862, and served with Lee's army in Virginia until his capture at Rappahannock Bridge in November 1863. The following January he died in the Union prison camp at Point Lookout, Maryland.

In addition to Wagner's own war letters, this collection includes several written by his wife and two of his brothers, who were also in Southern service. Like most letters of this type, the ones presented here are chiefly valuable for their descriptions of camp life and for their insight into the mind of the common soldier. Neither a slaveholder nor an extreme patriot, Wagner fought principally out of a sense of duty, and his attitude toward the war was summed up in the statement: "God onley knowes I am that tired of the war that I dont hardley know what to doo any more but I have to Bare it all patientley and you have to doo the same Dear." Although his morale declined noticeably after the battle of Gettysburg, he refused to follow the example of many of his comrades by deserting: "Dear Wife you neede not be a fraid that I will run a way I stick as long as I can and trust in my God to save me through this war safe and sound."

As these quotations indicate, the family descendants who have edited this volume have retained the original spelling, grammar, and punctuation, including a variety of Germanic speech patterns which reflect the Wagners' heritage. Also included are clarifying footnotes, a bibliography of standard secondary sources, and an index.

Henry A. Chambers, a native of Iredell County, came from a social background which was vastly different from that of the humble Wagner. Scion of a wealthy, distinguished family, he was raised by his cousin and guardian, who owned a large plantation and 125 slaves. After withdrawing from Davidson College in 1861, he enlisted in Company C of the 4th North Carolina. Later, in December 1862, he was appointed Captain of Company C, 49th North Carolina, the unit which he led until the end of the war.

Chambers's diary, which begins in January 1862, and ends in April 1865, portrays a welleducated, observant, and intensely patriotic young officer. Characteristically, he prayed after receiving his commission for "higher and nobler motives of action and purposes of life that I may leave the low, sordid, selfish and mean and strive after the honorable, upright, just, noble, and generous ..." His descriptions of military events include the battle of Fredericksburg, the Wilderness campaign, and the siege of Petersburg. Defeat at Appomattox called forth an impassioned outburst at the Yankees "who have burned our houses, desecrated our altars, plundered our wealth, waged unrelenting warfare upon the aged, the weak and helpless, [and worst of all] insulted and dishonored our lovely women!" Yet, like many former Confederates, Chambers found that time gradually healed these wounds: rereading the diary in 1923, he expressed surprise at 
"such bitter and vituperative language."

The editors have provided an extensive introduction, a bibliography of primary and secondary sources, and several indexes to accompany the text. Spelling, grammar, and punctuation have been edited to conform to standard usage.

Both of these fine books are recommended for purchase by academic libraries or by any institution that maintains a strong Civil War collection.

Everard H. Smith, High Point

Marguerite McCall. And Roofs Need Patching. Edenton, NC, 1982. 136 pp. \$9.98. (Order from Edenton Historical Commission, P.O. Box 474, Edenton, NC 27932)

Marguerite McCall's And Roofs Need Patching is the culmination of twenty years of world travel, observation, and life experiences. From its beginning as an outline in Hawaii in 1962 to its publication in Edenton in 1982, this first novel must have been a labor of love.

The northeastern North Carolina town of Riverlo watches as Ellen Simpson, daughter of the local feed and seed store owner, falls in love with Japanese-American Kenechi Kashimoto, who has left his native Hawaii to study agriculture at North Carolina State University. As in most of the country, sentiments in Riverlo toward JapaneseAmericans at the close of World War II were often hostile, and the marriage of Ken and Ellen seems to bring out the worst in many of Ellen's friends and relatives. Even Ellen's mother, bitter about the death of her son in combat, has become conditioned to hate all Japanese ("justifiable in her thinking, because one had killed her son"). Ellen, however, sees through the hypocrisy of churchgcers who are willing to accept someone of a different background and becomes more determined not to allow the prejudices of the town to dissuade her from marrying the man she loves. Meeting each difficulty with understanding and love, Ken and Ellen rely on their serenity and faith to carry them through the hard times. Ultimately, it is their kindness and unselfish giving which wins over even their harshest critics. It is only when tragedy shatters their perfectly planned life that Ellen's faith is shaken almost irretrievably.

There is a great hazard in writing a novel such as this, for all too easily characters can become unbelievably sweet and saintly and all realism can be lost. Rarely does an author achieve such balance as does McCall in this wellwritten story. Ellen and Ken are people we could know, with true goodness shining throughthoroughly believable, even familiar. Minor characters are similarly well-drawn, so true-tolife that they might indeed have inhabited any small North Carolina town. McCall has a gift for bringing a story to life and for involving the reader deeply in the life of the story.

And Roofs Need Patching is a vitally honest, truly moving, and joyous account of a faith shared, strengthened, and finally renewed, all the sweeter for having nearly been lost. This book is a small treasure for North Carolina libraries.

Julie White Sanders, Randolph Public Library

Robert A. Dentler, D. Catherine Baltzell, and Daniel J. Sullivan. University on Trial: The Case of the University of North Carolina. Cambridge, Mass.: Abt Books, 1983. 192 pp. \$28.00.

The University of North Carolina (UNC) desegregation case was big. It lasted sixteen years and went through four courts. Over $\$ 90$ million per year and the education of 110,000 students was at stake. Legal fees ran into the millions. This is the case that is the subject of University on Trial.

For those unfamiliar with the case, a brief summary may be helpful. In 1968 the federal Department of Health, Education and Welfare (HEW) ruled that ten states, including North Carolina, operated segregated public college systems in violation of Title VI of the Civil Rights Act. HEW ordered those states to submit corrective plans. By 1979 North Carolina was the only state left without an acceptable plan, as a result of which HEW began proceedings to cut off $\$ 90$ million in annual federal aid to the system. In 1981 UNC and the federal Department of Education ended fourteen years of legal battles by agreeing on a mutually acceptable desegregation plan.

The authors of University on Trial are members of a consulting firm that was heavily involved in the case on the side of the federal government, against UNC. They feel that in the thirty years since the Brown v. Board of Education decision, progress towards desegregating higher education in North Carolina has been insignificant. In their eyes the consent decree of 1981 was a sweetheart deal between UNC and Reagan appointees in the Department of Education which effectively denied the opposing side the opportunity to be heard in court. As a result, 
the authors decided to put forth their case in this book.

University on Trial attempts to answer several major questions raised by the case. First, is UNC segregated? According to the evidence presented, the answer is yes. Second, have traditionally black institutions (TBI's) received proportionally less in resources from the state than tradionally white institutions (TWI's)? Again the answer is yes. Third, will the plan agreed on in the consent decree eliminate inequities in the system? Readers, who must now be the judges, will disagree on this last question. The consent decree emphasizes upgrading the quality of the TBI's and stepping up minority recruitment. The authors say this is not enough. They believe that there must be structural changes in funding, more faculty and administration integration, and elimination of duplicate programs that put TWI's and TBI's in direct competition. Time will tell whether the UNC plan will work. We do know that in December 1983, two-and-a-half years into plan implementation, UNC reported they were behind in their integration goals.

University on Trial is the most complete account of the UNC desegregation case to date. It is well organized, with a useful index and many statistical tables to support assertions made in the text. Academic and larger public libraries will find it a valuable source of information on the case. Readers must remember, however, that it was written by people who opposed UNC in court. As such, it only provides information from one side of the courtroom and cannot be considered a definitive work.

For those who think the UNC case is no longer part of current events, a few observations are in order. Since University on Trial was written, the consent decree has been appealed all the way to the U.S. Supreme Court. That appeal was denied in February 1984. Also, in a separate but similar case in July 1983, the Department of Education rejected desegregation plans for five states, including the community college system in North Carolina. Finally, progress under the consent decree is under continuing scrutiny by federal court and civil rights groups. As the authors write near the end of University on Trial, the case lives on!

Edward Waller, Duke University

David Stick. Roanoke Island: The Beginnings of English America. Chapel Hill: University of North Carolina Press. 1983. 266pp. $\$ 14.95$ cloth, $\$ 5.95$ paper.
As North Carolina and the United States celebrate America's quadricentennial, interest and attention is increasingly riveted on Roanoke Island and the small bands of explorers and colonists who inhabited this sound region of North Carolina between 1584 and 1587. During the coming years, the public will be reminded constantly of the English beginnings of our nation. Along with a ship replica, public events, pageants, and a multitude of other celebrations, America's Four Hundreth Anniversary Committee has sponsored a series of publications designed to increase awareness and interest in the Raleigh colonization effort.

In Roanoke Island: The Beginning of English America, David Stick has provided the reader with a stimulating, informative, and highly entertaining account of this first attempt at English colonization of North America. With a flowing narrative style that is a genuine pleasure to read, $\mathrm{Mr}$. Stick places the Roanoke voyages in proper perspective by exploring the background of British colonization; the struggle between Elizabethan England and Spain for the New World domination; and the exploits of Sir Walter Raleigh as courtier, speculator, and colonizer. The primeval splendor of the Carolina coast becomes the lush backdrop for the colonization efforts of a people seemingly more concerned with pilfering Spanish wealth than with assuring a permanent English foothold in North America. The Amadas and Barlowe expedition of 1584, the Ralph Lane-Richard Grenville colony of 1585, and the John White effort of 1587 are all treated factually and in considerable depth. The responsibility for Indian hostilities is properly placed on the shoulders of the English colonists themselves due to their insensitivity and at times barbarous treatment of the "heathern savages." By the same token, at least part of the blame for John White's "Lost Colony" rests in the indifference and evolving business priorities of Walter Raleigh himself. The volume also provides keen insight into English preoccupation with the Spanish West Indies and the effects of privateering enterprises on the colonization efforts.

Mr. Stick is well known to the North Carolina reading public as the author of Graveyard of the Atlantic, The Outer Banks of North Carolina, 1584-1958, and Dare County: A History. He brings to this new publication an understanding of and appreciation for the Outer Banks of North Carolina that add dramatically to the clarity of the book. In Roanoke Island, Mr. Stick has crafted an excellent account of the Raleigh colonization adventure. This volume should have a strong appeal to the general public as well as to 
the student of history. Some historians will object to the brevity of the bibliography and the lack of footnotes; but for a popular history, the format of textual source references is well suited to the purpose of the volume. Without question, Roanoke Island should be in all public libraries, and it is highly desirable for public school and college use. It obviously has merit as parallel reading for history students; instructors will have few complaints from students who undertake the book as assigned reading.

Domald R. Lennom, East Carolina University

Carole Marsh. The Mystery of the Lost Colony. Tryon, NC: Gallopade Publishing Group, 1983. 84 pp. $\$ 4.95$ paper.

Another in the Marsh series of History Mystery books, The Mystery of the Lost Colony places the young protagonists not in the mystery but in a contemporary one set along the Outer Banks. A strong point of the book is the opportunity the format gives to introduce readers to snippets of history and local lore about the Roanoke IslandOuter Banks area.
Jeremy Mydet, from Roanoke Island, and his friend Dennis, from Ocracoke, are all set to enjoy the four hundredth anniversary festivities when an ominous series of circumstances is set in motion. First, his grandfather's silver commemorative coins disappear, soon followed by a vanishing manuscript. Objects are not the only things affected by these happenings-Jeremy is very nearly drowned, and Dennis is briefly drugged and kidnapped. Is the antagonist mortal, or do the blood-stained tombstones and ghostly Nag's Head light suggest a more sinister source of the intrigue?

What this mystery offers in terms of adventure, however, is marred by several deficiencies. One, the lack of smooth transition often leaves the reader wondering whether he has missed something. For example, one chapter ends with poor Jeremy drowning, "breathing in great globules of the poison water of the past." The reader, too, is left gasping as the following chapter begins by skipping merrily through two seasons to the old Christmas celebration, with nary an explanation of how Jeremy survived.

Only the most cursory characterization is accomplished, even for the two young lads who carry this adventure; none of the characters is

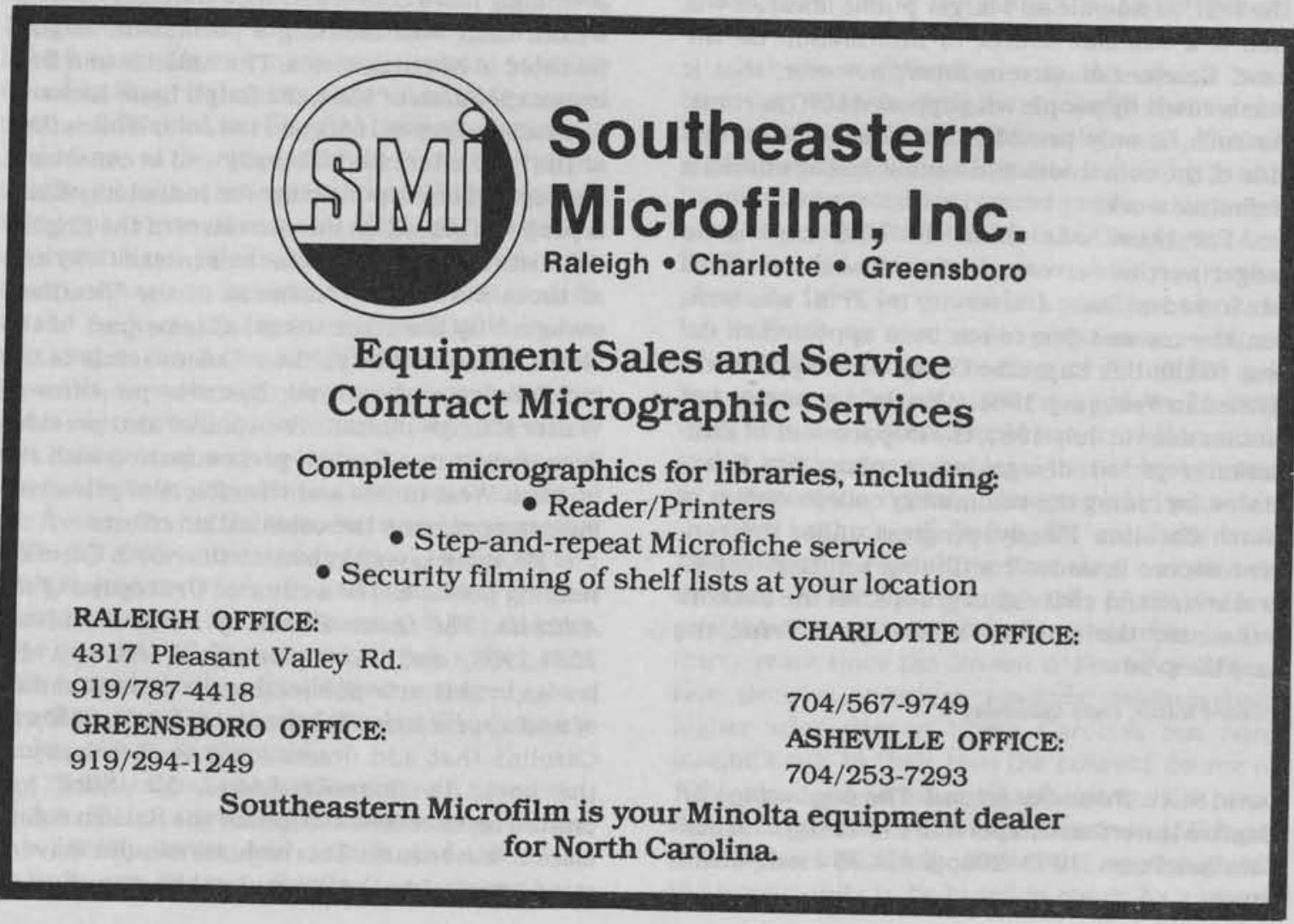


really brought to life, nor are motivations strongly explored.

Another distraction is the frequency of typographical or printing errors, including a missing page.

While the quality of this book may not be what one would hope for, the paperback format, short chapters, appropriately somber black-andwhite illustrations, and familiar setting should add to its appeal for upper elementary and middle school readers, from whom it is most suited. And if the tidbits about the Outer Banks induce further reading on the subject, perhaps Marsh will have accomplished her purpose, "to introduce the area and its role in America's heritiage to children around the world."

Jane Wade, University of North Carolina at Greensboro
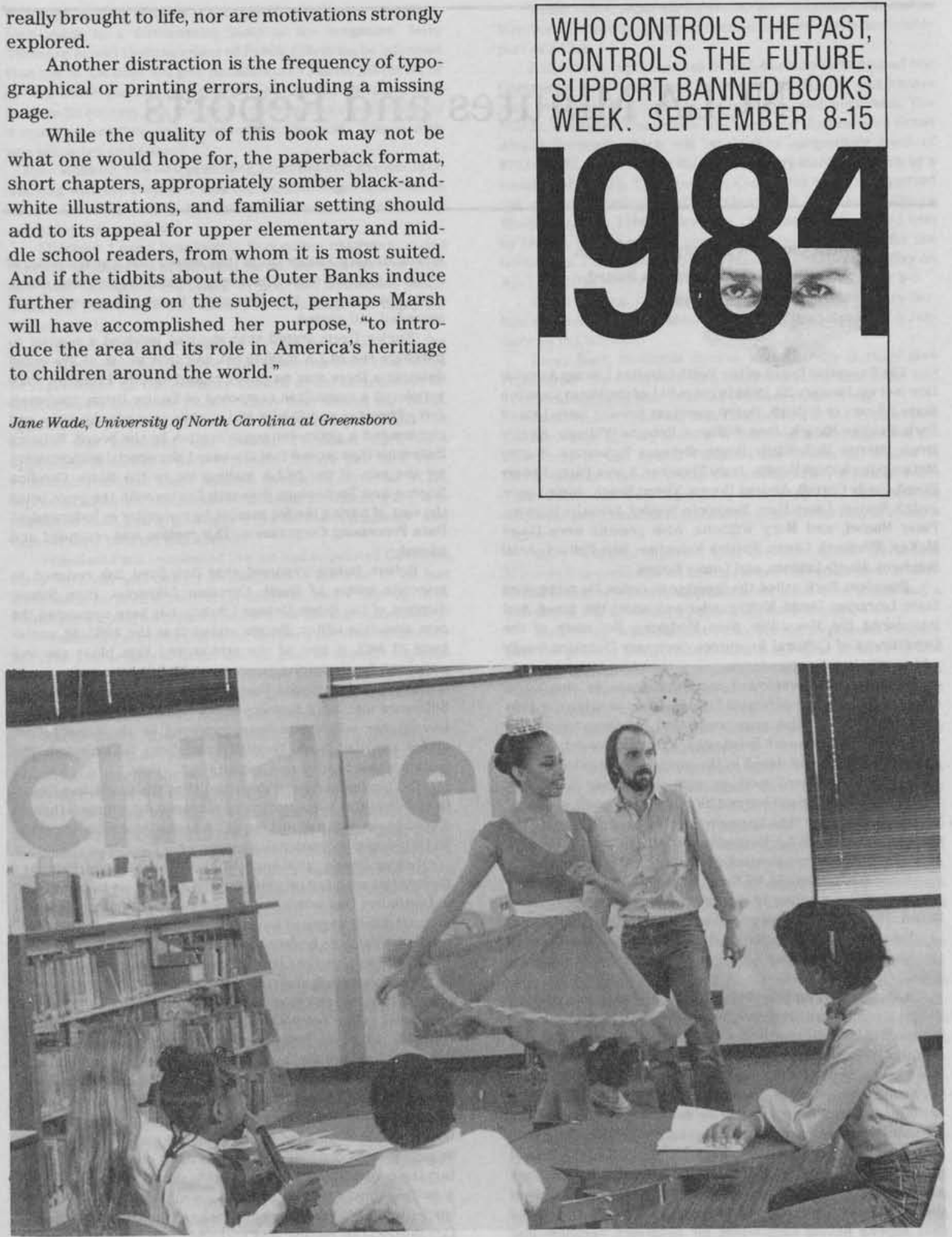

Deneen Graham, Miss North Carolina 1984, who stars in a public service announcement publicizing this year's statewide summer reading program, "North Carolina Celebrates: 1584-1984." The program is designed to coincide with the beginning of the threeyear-long observance of America's four hundredth anniversary and is funded through Title I of the federal Library Services and Construction Act. 


\section{NCLA Minutes and Reports}

\author{
North Carolina Library Association \\ Minutes of the Executive Board \\ January 20, 1984
}

The Executive Board of the North Carolina Library Association met on January 20,1984 in room 211 of the North Carolina State Library in Raleigh. Board members present were Leland Park, Pauline Myrick, Jane Williams, Roberta Williams, Eunice Drum, Mertys Bell, Emily Boyce, Rebecca Ballentine, Shirley McLaughlin, Robert Burgin, Jerry Thrasher, Karen Perry, Robert Bland, Emily Correll, Andrea Brown, Vivian Beech, Judie Davie, Judith Sutton, Larry Barr, Benjamin Speller, Dorothy Burnley, Patsy Hansel, and Mary Williams. Also present were David McKay, Elizabeth Laney, Patrick Valentine, Bob Pollard, Arial Stephens, Marge Lindsey, and Louise Boone.

President Park called the meeting to order. He recognized State Librarian David McKay, who welcomed the group and introduced the Honorable Sara Hodgkins, Secretary of the Department of Cultural Resources. Secretary Hodgkins briefly addressed those in attendance.

The President extended congratulations to the North Carolina Association of School Librarians on winning the 1984 Grolier Award. He also announced that Dr. Gene Lanier has won ALA's 1984 Immroth Intellectual Freedom Award.

A correction was noted in the minutes of the October 25 , 1983, Executive Board meeting, with the phrase "exhibitors numbered 107 " changed to read "90 exhibitors' booths rented." These minutes were then approved as corrected. Minutes of the October 28, 1983, NCLA business meeting and the October 28 , 1983, Executive Board meeting were approved as presented.

A motion was made by Emily Boyce to dispense with the reading of the minutes at future meetings of the Executive Board. The motion was seconded and passed.

President Park reported to the group on his meeting with the North Carolina State Library Commission on January 19, 1984.

A final report on the 1983 NCLA Conference was given by Robert Burgin, Arial Stephens, Robert Pollard, Leland Park, and Mertys Bell. Burgin reported a final registration of 1,273 and rental of 90 exhibitors' spaces. It was noted that the conference was financially successful.

Pauline Myrick gave a report on plans for the 1985 NCLA Conference. Arial Stephens will be conference manager, with Johnny Shaver in charge of local arrangements. Bill Kirwan will be chairman of exhibits, with Fred Marble and Larry Roland representing the exhibitors. NCLA President Dr. Leland Park and Treasurer Eunice Drum will serve as ex officio members of the Conference Planning Committee. Chairman Myrick asked that anyone having suggestions for programs, speakers and other arrangements for the 1985 conference contact her or other members of her committee.

The treasurer's report was given by Bob Pollard, immediate past treasurer, and Eunice Drum, treasurer. Eunice Drum stated that membership renewal notices would be mailed by the end of January. Eunice Drum then moved that it be the policy of NCLA to pay only what is authorized by the budget unless otherwise approved by the Executive Board. The motion was seconded and passed.

Eunice Drum stated that she had received a request to purchase the NCLA mailing list and that as far as she could determine there was no policy regarding this. President Park appointed a committee composed of Eunice Drum, chairman, Jerry Thrasher and Shirley McLaughlin to study this issue and recommend a policy for consideration by the board. Rebecca Ballentine then moved that the board give special authorization for the sale of the NCLA mailing list to the North Carolina Science and Technology Research Center with the price being the cost of having the list printed by computer at Independent Data Processing Corporation. This motion was seconded and passed.

Robert Burgin reported that Bob Byrd has resigned as associate editor of North Carolina Libraries. Rose Simon, director of the Salem College Library, has been appointed the new associate editor. Burgin stated that the 1983/84 winter issue of NCL is now at the printer and that plans are well underway for the spring, summer, and fall 1984 issues.

Emily Boyce moved that changes in the by-laws for the Reference and Adult Services Section and the Junior Members Roundtable, which had been approved by the Constitution, Codes and Handbook Revision Committee, be accepted. The motion was seconded and passed.

Dr. Benjamin Speller reported that the Goals and Objectives Committee is continuing its efforts to determine if there is a need to develop a model for NCLA to consider with respect to its future as a professional organization.

Louise Boone, chairman of the Governmental Relations Committee, reported on plans for NCLA members to participate in Legislative Day activities on April 10 in Washington, D.C. She requested that names of individuals who will represent the various NCLA Sections be forwarded to her by March 1.

The report for the Library Resources Committee was given by Patrick Valentine, chairman. He announced that the committee still has on hand four hundred copies of the disaster preparedness guide. Jerry Thrasher moved that the chairman of the NCLA Library Resources Committee be empowered to advertise and sell the publication, Disaster Preparedness: $A$ Guide for Developing a Plan to Cope with Disaster for the Public and Private Library, for $\$ 4.00$ per copy. The chairman of the Library Resources Committee is to coordinate with the NCLA treasurer concerning deposit of revenues and reimbursements or advances for costs incurred. The present chairman will maintain the responsibility for handling the advertising and sales for a twelve-months period, after which all responsibility will be turned over to the incoming chairman of the Library Resources Committee. The motion was, seconded and passed. Elizabeth Laney then moved that any surplus income derived from the sale of the disaster preparedness guide be used to republish the guide in a more convenient form. This motion was also seconded and passed.

Patrick Valentine stated that the editor of Public Libraries 
had expressed an interest in publishing the disaster preparedness guide in a forthcoming issue of the magazine. Jerry Thrasher moved that the editor of Public Libraries be informed that the NCLA does not give permission to Public Libraries or to any other publication to print the disaster preparedness guide in its entirety, but that NCLA does welcome publication of a summary or other short references to the guide. This motion was seconded and passed.

Jane Williams, 2nd vice-president, reported that she would be working with the treasurer and the Membership Committee to review the membership list and consider plans for actively recruiting new members.

Elizabeth Laney, Scholarship Committee chairman, stated that the scholarship application forms were unchanged from last year. She asked the board to help the committee locate deserving individuals who should be encouraged to apply for the scholarships.

President Park then asked for a recommendation from the board in response to a request from Governor Hunt that NCLA be represented on the Advisory Council to the Commission on Education for Economic Growth. Larry Barr moved that NCLA appoint two members to serve on the Advisory Council. The motion was seconded and passed. President Park then appointed Immediate Past President Mertys Bell and VicePresident/President-Elect Pauline Myrick to serve as NCLA representatives on the Advisory Council. President Park also requested that board members write to the commission and express their interest and support.

President Park announced that he had appointed Directors Jerry Thrasher and Shirley McLaughlin to serve on an ad hoc committee to review the NCLA minutes and come up with recommendations for a policy manual for the Executive Board.

President Park then discussed the need to review and study the future directions of NCLA and his plan to appoint a special committee to do this. Benjamin Speller moved that the board approve the appointment of a committee to study the future of NCLA. The motion was seconded and passed.

Karen Perry, chairman, Children's Services Section, reported that plans are being made for a program during the fall of 1984 and also for the conference program in 1985. A special committee to address the topic, "Standards for Children's Services in Public Libraries," has been appointed and will be chaired by Nina Lyon, children's coordinator of the CharlotteMecklenburg Public Library. A joint committee of the Children's Services Section and the North Carolina Association of School Librarians will continue to investigate the establishment of a North Carolina Children's Book Award.

Robert Bland reported that the College and University Section is planning a conference for late spring or early summer on the relationship between the library and the administrator. A questionnaire seeking to gain information on needs and future goals of the section is being prepared and will be distributed to members of this section.

The report of the Documents Section was given by Emily Correll, chair. A workshop on international documents is planned for April 19th at the Durham County Public Library. The section is also planning a series of workshops on the selection and use of basic North Carolina documents. These will be held regionally throughout the state in the fall.

Andrea Brown gave the report for the Junior College Section. Plans are underway for an aggressive membership campaign for this section. The section will request space in "The Mediator," the newsletter of the North Carolina Community College Learning Resources Association, to publicize the goals and activities of the section. The section also plans to investigate the possibility of cosponsoring a workshop with the College and University Section.
Vivian Beech reported for the Junior Members Roundtable. Members are seeking ways to become a more visible and viable part of NCLA.

Judie Davie reported that NCASL has established an ad hoc Committee on Committees to review all NCASL committees with attention to guidelines, procedures, and personnel. The NCASL Executive Committee has approved the Research Grant Award Proposal which will establish a competitive grant of $\$ 25.00$ to $\$ 1,000.00$ a year for school library media research by a member of NCASL. The Executive Committee has also approved the national marketing of the Guidebook on School Library Media Day. The $\$ 1000$ prize from the 1984 Grolier Award won by NCASL will be used to produce marketing publicity for the Guidebook. Davie also discussed plans for School Media Day on April 11, 1984, and a work conference to be held October 3-5.

Judith Sutton, chair, reported that the Public Library Section will hold its first Planning Council of the biennium on January 26 in Charlotte.

Larry Barr, Benjamin Speller, and Dorothy Burnley gave reports for the Reference and Adult Services, Resources and Technical Services, and Trustees Sections respectively.

Patsy Hansel reported that Tindara Foti of the Cumberland County Public Library is the new editor of MsManagement, the newsletter of the Round Table on the Status of Women in Librarianship. Plans are underway to establish a Round Table Task Force on Pay Equity. A workshop on documenting employee performance is tentatively planned for May in Forsyth County.

Mary Williams reported that the Roundtable for Ethnic Minority Concerns has set several important goals for this biennium. Initial committee appointments have been made and a newsletter will be edited by Sylvia Sprinkle-Hamlin.

Both Mary Williams and Patsy Hansel expressed concern that the present NCLA constitution is not clear on the role and function of roundtables as opposed to sections within the NCLA framework. Emily Correll moved that the Constitution and Codes Committee consider the status of roundtables vs. sections and report to the Executive Board at its next meeting. The motion was seconded and passed.

Emily Boyce, ALA representative, reported on the ALA midwinter meeting. A committee for the Federal Highway Administration has rejected an ALA proposal that the national library symbol be used as a traffic service sign. The committee recommended instead a sign with white lettering on a green background, using the word library as a directional sign. A gradual five-year escalated dues increase to take effect in 1985 was passed by ALA Council. Council also passed two memorial resolutions in tribute to $\mathrm{Dr}$. Annette Phinazee.

Rebecca Ballentine, SELA representative, reported on plans for the 1984 SELA Biennial Conference to be held at Biloxi, Mississippi, October 15-20. A Reference and Adult Services Workshop will be held in Atlanta, May 10-12. A four-day institute on intellectual freedom at Florida State University is planned for late July or August. Emphasis will be on censorship in public and school libraries.

Arial Stephens, NCLA representative to the Network Steering Committee, reported that two pilot ZOCs have been established.

Shirley McLaughlin stated that she had been asked by the Executive Board of the Western North Carolina Library Association to ask the NCLA Executive Board whether WNCLA could affiliate in some way with NCLA. It was decided to consider a formal request from WNCLA at a future meeting of the NCLA Board.

Jerry Thrasher announced that the North Carolina Public Library Directors Association will meet in Raleigh February 23 24. The program will include a "Meet the Candidates" forum in 
which candidates for the state legislature or their representatives will be present to discuss issues and answer questions of interest to librarians.

President Park reminded everyone of the April 6-7 board meeting and Spring Workshop to be held at Greensboro College.

There being no further business, the meeting adjourned.

\section{Roberta S. Williams, Secretary}

\section{Children's Services Section}

The Children's Services Section Executive Board has not met during this quarter. Plans have been made to meet on January 21 in Greensboro and on March 27 in Raleigh.

Section committee organization and meeting schedules will be completed shortly. Plans are being made for a program during the fall of 1984 and for the conference program in 1985. The program committee is now headed by the vice-chair of the section, as directed in the last change in CSS bylaws. The vice-chair for this biennium is Rebecca Taylor.

A special committee to address the topic "Standards for Children's Services in Public Libraries" has been appointed and will be chaired by Nina Lyon, children's coordinator of the Charlotte-Mecklenburg Public Library System. This committee will use Guidelines for Public Library Service to Children, a publication of the Children's Librarians Section of the Illinois Library Association, as a model.

A joint committee of the Children's Services Section and the N.C. Association of School Librarians will continue to investigate the establishment of a North Carolina Children's Book Award.

\section{Karen M. Perry, Chairman}

\section{College and University Section}

The CULS Executive Board met on December 2, 1983, and again on January 20,1984 . The Board began planning a conference, which will take place in the late spring at a site and time to be announced. The theme of the conference is planned to be library-faculty and college administration relationships.

Following the December 2 meeting the board cooperated to get an informational mailing to the membership, which included a questionnaire soliciting ideas and opinions on directions and programs the section should sponsor.

\section{Robert Bland, Chairman}

\section{Documents Section}

The Executive Board of the Documents Section of NCLA met in Winston-Salem on November 8 to discuss programs for the coming year. A workshop on international documents is planned for April 19 at the Durham Public Library and will concentrate on basic international collections for schools, public libraries, and Model UN programs. It will also provide some guidance in the use of international documents for special libraries. The section is also planning a series of workshops on the selection and use of basic North Carolina documents for all types of libraries. These workshops will be held in the fall in various sections of the state.

\section{Emily Correll, Chair}

\section{Junior College Section}

The Board of the Junior College Section met January 13, 1984 at St. Mary's College. The board reaffirmed the need for a section devoted to the goals and concerns of private junior colleges and community colleges. The board voted to initiate action to change the name of the section to more accurately reflect the section's membership. Preliminary plans were made for an aggressive membership campaign. The section will request space in "The Mediator," the newsletter of the North Carolina Community College Learning Resources Association (LRA) to publicize, on a regular basis, the goals and activities of the section. Additional plans were made to strengthen communication with the section's members. The board voted to seek cosponsorship of a workshop with the College and University Section. The chairman contacted Robert Bland, chairman of the section, and there is mutual interest in such a venture. We will meet following this meeting to discuss this further.

The board voted to conduct more worthwhile activities for the section's membership, to raise the visibility of the section, and to make personal contact with potential members.

\section{Andrea P. Brown, Chairman}

\section{North Carolina Association of School Librarians}

The North Carolina Association of School Librarians began the biennium with the 1983 NCLA Conference that provided the setting for the first jointly sponsored program with the Children's Services Section ("The Open Door"); a well-attended luncheon with Lillian Gerhardt, editor of School Library Journal, as keynote speaker; and a workshop to coordinate the activities for School Library Media Day, 1984.

The NCASL Executive Committee met in Greensboro on Friday, December 2, to review the activities of the previous biennium and to set priorities for the present biennium with consideration of the topics and issues that were discussed at the regional forums during spring 1983 and that had emerged during the summer and fall 1983. Of particular concern were how the association could best serve its membership and increase awareness of the value of school library media programs in North Carolina, administered by certified school library media specialists. The Executive Committee approved the continuation of the publication and program activities of the previous biennium and the establishment of several ad hoc committees. An Ad Hoc Committee on Committees will review NCASL committees with attention to guidelines, procedures, and personnel. The Awards and Scholarships, Standards, and Budget Committees will be the first committees for review. An Ad Hoc Committee on a Supervisors' Round Table will investigate the feasibility of such a round table for NCASL and supervisors. An Ad Hoc Committee on the Children's Book Award, working with a similar committee from the Children's Services Section, will refine the guidelines for the award. The Executive Committee approved the Research Grant Award Proposal which will establish a competitive grant of $\$ 25$ to $\$ 1000$ a year for school library media research by a member or members of NCASL. The Executive Committee also approved the national marketing of the guidebook on School Library Media Day.

The Administration of the Year Award was presented to Dr. E. Wayne Trogdon, superintendent, Alexander County Schools, on December 6 at the annual meeting of the North Carolina Association of School Administrators.

Joseph M. Johnston, executive director of the Commission on Secondary Schools of the Southern Association of Colleges and Schools, acknowledged the receipt of the results of the survey by the Standards Committee during 1981-1983.

On January 9, NCASL was notified that the association had been awarded the 1984 Grolier National Library Week Grant. The award of $\$ 1000$ will enable the distribution of the guidebook on School Library Media Day to other agencies and associations in North Carolina and the duplication of a public service 
announcement videotape. The 1984 grant was the first ever awarded to a state school library association.

The American Association of School Librarians has requested the publication of the NCASL program brochure "Volunteers in the School Media Center" as a "Quick Note" in Spring 1984. The brochure was originally developed by the Winston-Salem/Forsyth County Schools, Arabelle Fedora, coordinator of media services.

Activity and attention for the Association focus on the successful implementation of School Library Media Day, April 11, 1984 !

\section{Public Library Section}

The Public Library Section is ready to begin an industrious biennium. Committees were appointed and charges issued when the Executive Board of the section met December 6, 1983, in Durham. The first meeting of the section's Planning Council is scheduled for January 26 in Charlotte. Among items to be discussed is the salary plan for public library directors and librarians proposed by the NC Public Library Directors Association with the endorsement of the PLS Executive Board and now being considered by the NC State Library Commission. A full report of the Planning Council session and other section business will be made at the next NCLA Executive Board meeting.

\section{Judith K. Sutton, Chairman}

\section{Roundtable for Ethnic Minority Concerns}

President Leland M. Park, members of the 1983/85 Executive Board of the North Carolina Library Association, and interested persons.

It is with pleasure that I share this historic report to the North Carolina Library Association Executive Board. And at the same time relate the message delivered at the organizational meeting last October.

This roundtable "is not a repeat of history but history itself since minorities are uniting under the North Carolina Library Association as a visible and viable entity of the Association.

"If this Roundtable were to receive a charge I hope that it will foster and challenge every ethnic librarian to participate in NCL.A. Thus this Roundtable will be a channel that expresses and represents interests and/or concerns of ethnics and serves as a liaison between NCLA's administrators, the affiliated ethnic librarians, and nonaffiliated ethnic organizations. Remembering always that it will not separate ethnic librarians from the mainstream of NCLA but increase the awareness of all librarians to the needs and problems of this particular segment of a community. This Roundtable shall be a forum for librarians concerned with the challenges facing ethnics and ethnic librarians.

"Please let us plant that thought in the subconsciousness of our mind,"

This biennium, the administration REMCo will be a shared one. I am presently suggesting the following:

Ms, Sylvia Sprinkle-Hamlin will handle our newsletter and serve on the publications board of NCLA.

Ms. Euthena M. Newman will serve as our coordinator of events.

Mr. Clarence Chisholm will assist with planning and projections.

\section{Round Table on the Status of Women in Librarianship}

The Executive Board of the Round Table on the Status of Women in Librarianship held its first meeting of the biennium January 18,1984 , at the Forsyth County Public Library.

Tindara Foti, Cumberland County Public Library, was introduced as the new editor of the round table's newsletter, Ms. Management. Mary McAfee was recognized as the Round Table's representative to North Carolina Libraries.

The board discussed a number of ideas for round table activities during the biennium. It was decided to proceed immediately with establishing a round table task force on pay equity to keep the membership aware of pay equity activities within the state and the nation, as well as to plan other projects relating to pay equity. Pat Grim and Mary McAfee will be organizing a workshop on documenting employee performance that is tentatively scheduled for May in Forsyth County.

The board decided to hold its next meeting prior to the workshop in May.

\section{Patsy Hansel}

\section{Resources and Technical Services Section}

The RTSS Executive Committee will hold its first meeting of the $1983 / 85$ biennium on January 27,1984 , at Guilford Technical College in Jamestown, North Carolina. The major focus of the meeting will be to review the activities of the section and its interest groups for the previous biennium, including the NCLA Biennial Conference. The committee will consider plans for 1984 and the need for distribution of a revised RTSS survey to solicit program ideas from the membership at large.

The chair plans to establish a meeting schedule for the committee in keeping with the projected meetings of the NCLA Executive Board.

Benjamin F. Speller, Jr., Chair

\section{SELA Report}

The SELA Board met in Atlanta on December 13.

1. Reference and Adult Services Workshop in Atlanta's Duntree Hotel on May 10-12 (Thursday-Friday). The workshop will address goals and standards; personnel management and development; training for both professional and nonprofessional staffs; stress management; and managing the reference department (innovations and how to work through the administration to get programs adopted). CEUs will be offered. (Valdosta College will bank CEUs for all SEL,A programs that offer credits.) 2. To be announced: a four-day institute on intellectual freedom at Florida State University Center in Tallahassee in late July or August, sponsored with FSU. Emphasis will be on censorship in public and school libraries.

3. 1984 Biennial Conference, Mississippi Gulf Coast, Convention Center at Biloxi, October 15-20.

a. Pre-conference on public relations sponsored with MLA and conducted by LAMA.

b. Eudora Welty will appear on a panel.

c. Workshop on consultants, including state agency consultants, to demonstrate how their talents can be used. SELA is looking for suggestions for speakers.

d. John Maxwell's one-man show on Faulkner.

e. Amtrak service to New Orleans. (World's Fair ends week after the conference.)

f. Trustees Section with the Public Libraries Section: "The Changing Role of Public Libraries." Dr. David Matthews has been asked to speak on national issues but had not responded as of December 13.

4. Ann Morton, SELA executive secretary, is resigning in January to join the Library School faculty at Emory. The SELA Executive Committee will conduct a search for a replacement.

5. The Southeastern Librarian must publish four issues to maintain its present postal rate. One issue is in press, another issue is 
in planning stages. Linda Lucas, editor, has enough content to publish but would welcome contributions.

6. Nominating Committee: Neil Austin has been nominated for SELA treasurer. I have the slate of nominees if anyone would like to see it. It will be published in the journal.

7. Conference Sites:

1986 - Atlanta, Mariott Hotel, October 15-19

1988 - Norfolk, last week in October (Winston-Salem also made a good bid.)

1990 - Looking at New Orleans (LA is new SELA member) and Nashville, TN.

\section{Rebecca Ballentine, SELA Representative}

\section{American Library Association Midwinter Meeting: A Report}

Council. Executive Director Robert Wedgeworth reported that the association had recovered from the fiscal deficit of last year. He noted that the auditor's report concluded that ALA had a strong financial base but remained cash poor. He said it was important to retain members as a further insurance against fiscal difficulties in the future. Mr. Wedgeworth identified objectives for 1985-1989. The association would eliminate the use of accrued income, establish operating reserves, and restore programs previously cut.

As a follow-up to ALA's adoption of the national symbol at the Annual Conference in 1982, ALA recommended to the Federal Highway Administration (FHWA) that a new service sign representing libraries be added to the Manual on Uniform Traffic Control Devices. Earlier this year an advisory committee to the FHWA reviewed the ALA proposal and recommended that the use of the symbol be rejected. Instead, the advisory committee recommended that a sign using the word message LIBRARY be adopted with white lettering on a green background since it would be considered a directional sign. It is anticipated that this recommendation will be published for public comment by the FHWA in the Federal Register in early 1984 for a ninety-day comment period.

In order to make an effective response to the Federal Register notice, ALA will need photos and other examples of the symbol already in use on directional signs to libraries. If you wish to support the ALA-proposed symbol, send this information to Peggy Barber, ALA Public Information Office, American Library Association, 50 E. Huron Street, Chicago, IL 60611.

The Committe on Program Evaluation and Support (COPES) presnted a proposal for a dues increase to take effect in 1985. The dues increase includes a five-year gradual escalation, retains the present membership categories, and encourages the retention of divisional membership. This proposal was passed by Council and will be presented to the full membership for a mail vote:

President Sheldon reported the establishment of a task force to prepare a response to A Nation at Risk. Four papers will address the role that libraries have in the educational process and will identify needs libraries have in meeting eduttational obligations.

Council passed a resolution recommending that the Continuing Library Education Network and Exchange (CLENE) become a round table.

Two memorial resolutions in tribute to Dr. Annette L. Phinazee were passed by Council.

Grolier National Library Grant Awarded. ALA's National Library Week Committee has selected the North Carolina Association of School Librarians to receive the 1984 Grolier National Library Week Grant. Dr. Judie Davie, chairman of the North Carolina Association of School Librarians, submitted the proposal to the National Library Week Committee. The $\$ 1,000$ grant will help the association spousor the first North Carolina School
Library Media Day during National Library Week 1984. Through displays, news releases, contests, and special events, the association is working to promote an awareness of the value of good school library media programs in North Carolina. The 1984 grant will be the first awarded to a state school librarians association. The annual grant is contributed by the Grolier Educational Corporation.

Chapter Conclave. The conclave offers an opportunity for chapter councilors to meet as a group and discuss issues facing the Association which could be of particular interest to various states. In Washington, the councilors agreed to make a strong effort to convince ALA's management to restore the chapter relations officer to full-time.

ALA's Presidential candidates, Ms. Beverly Lynch and Ms. Virginia Matthews, addressed the group, outlining their platforms and answering questions. Topics discussed included the role of chapter councilors in the political process, telecommunications, UNESCO, continuing education, the work of the Washington office, and the proposed ALA response to $A$ Nation. at Risk.

President's Program. The first segment, chaired by Gary Strong of the Legislation Committee, had two distinct parts. The first, addressed by Walter Bolter and Joseph Ford, discussed the growing concern over the proposed telephone company local access charges and their impact on the electronic transfer of information among libraries. HR 40-102 is currently under discussion in Congress and would overturn the access charge for residences and small businesses. Bolter emphasized the need for librarians to support omission or phasing in of the tariffs and a lowering of the rate increase to allow libraries time to search for alternative communication methods. Another strategy mentioned by Bolter is the possibility of libraries applying for exemptions from the increased charges as other groups have already done.

In the second portion of the legislative update, the audience heard from Robert Gellman, counsel, House Subcommittee on Government Information. He explained that Executive Order 12356, signed by President Reagan, put into effect new rules for security classification, making it easier to classify information, thereby exempting it from the Freedom of Information Act. Gellman also noted a decrease in governmental statistical activities and publications since the beginning of the Reagan administration. His suggestion to librarians concerned about the above issues is to contact their legislators and make their lobbying presence known. Two informational sheets prepared by the ALA Washington Office elaborate on the above issues: "Drastic increases in telecommunication costs facing libraries" and "Less access to less information by and about the U.S. Government: III."

Brooke Sheldon hosted the second segment of the President's Program, entitled "Libraries, Literacy and a Nation at Risk."

Barbara Bush, wife of the vice-president, commented libraries on their efforts to encourage literacy among the American people and likened the job libraries are doing to planting a flower-they both take a great deal of initial work but the results last for many years.

The panelists were introduced by Sheldon. Elaine Stienkemeyer, president of the National Parent-Teacher Association, stated that her organization emphasizes the role of parents in taking pleasure in reading to their children. A President's Award has been established for excellence in reading and is presented to local chapters for exemplary programming. Her comment that "we want children to learn how to think, not what to think" was warmly applauded by the audience.

Dorothy Ridings, president of the National League of Women Voters, explained the current warm cooperation between libraries and LWV units. She felt that her group's strong- 
est assistance would lie in the arena of supporting local public policy initiatives and sponsorship of public forums on illiteracy.

The last panelist, James Fowler, president of Lions International, reviewed his organization's sixty-seven year association with libraries and their support programs for persons with failing sight. He announced that a cover story on illiteracy would be done in the organization's periodical by late 1984 and that the national Lions Board has voted approval of the 1984 National Library Week campaign. Fowler asked everyone present to inform their local Lions Club of the seriousness of the illiteracy problem in their own community and ask for help to solve it.

Secretary of Education Terence Bell thanked libraries for being the "cornerstone of education and learning." He encouraged other private companies to follow the lead of B. Dalton and IBM in giving financial aid to libraries and literacy efforts. Bell presented a $\$ 50,000$ award from the Department of Education for the Literacy National Awareness campaign to Robert Wedgewood and Jean Coleman of ALA.

In the third segment of the program, Arch Lustberg of the U.S. Chamber of Commerce gave a fast-paced and informative presentation on the skills of platform speaking and how to handle confrontations. He showed videotapes of sample budget presentations and critiqued them for the audience. He enphasized that you've got some who agree with you, some who oppose you, but you need to persuade the third group-the ones who are unsure; that an audience can react to you with like, dislike, neutrality, or sympathy for you; that confrontation involves the weapons of intelligence, facial features, and body stance; that the two elements of platform skills are "the pause" and eye contact; that breathing correctly helps you to deal with stressful situations; and that volume is the most misused vocal tool.

Emily Boyce, Chapter Councilor

\section{Statement from the \\ North Carolina Association of School Librarians}

Presented at the Greensboro hearing of the North Carolina Commission on Education for Economic Growth.

\section{The School Library Media Program and \\ The School Library Media Coordinator}

\section{Contributors to Excellence in K-12 Education}

Recent studies of education have recommended strongly that schools better prepare students for lifelong learning. A frequently identified survival skill is the ability to locate, generate, evaluate, apply, and appreciate information. The school library media program, through learning activities, educational resources, and services, provides the opportunities for children and young adults to achieve this goal. As the educational community strives for excellence, the school library media program, administered by the school library media coordinator, can be a significant contributor to and partner in educational progress.

\section{The school library media coordinator:}

- instructs all students in information retrieval skills and in the use of materials that contribute to lifelong learning, e.g., how to find relevant information in reference books, information files, data bases.

- plans with teachers to provide materials and equipment appropriate for student learning, e.g., books for reading enrichment, tapes for listening skills, films for critical viewing experiences, microcomputers for programming.
- develops and organizes collections of appropriate materials to achieve the instructional objectives of $\mathrm{K}-12$ education, e.g. magazines, microcomputer software, videotapes, books, professional materials for teachers.

- participates in resource sharing and networking to supplement the materials and equipment in the individual school, e.g. school-public cooperation for efficient use of community resources, interlibrary loan, telecommunications.

- provides leadership in the careful expenditure of funds for educational resources that help teachers individualize instruction, e.g., cooperative purchasing, state contracts.

- administers the school library media program as an integral part of the curriculum, e.g., planning, implementation, evaluation, instruction, production, and reading, listening, and viewing guidance.

\section{The school library media program requires:}

\section{PERSONNEL}

Professional: for each school, a minimum of one full-time media coordinator, certified with competencies in teacher education, selection and evaluation of materials, organization and management of collections, production and use of resources, and administration of the school library media program. (One media coordinator/enrollment to 499 students.)

Support: clerical and technical aides in sufficient numbers to perform the nonprofessional functions of the school library media program. (One clerical/technical aide/enrollment to 499 students.)

\section{RESOURCES}

Print: a minimum of ten books per student, thirty magazine subseriptions, two newspapers plus information file materials for schools with fewer than 400 students.

1983 average cost per book:

$\begin{array}{ll}\text { Grades K-3 } & \$ 11.33 \\ \text { Grades } 4-8 & \$ 11.53 \\ \text { Grades } 9-12 & \$ 12.88\end{array}$

1983 average cost per set of encyclopedias $\$ \$ 483.00$

1983 average magazine subscription $\$ 27.44$

(up 27 per cent in 1983)

Nonprint: microcomputer software, recordings, filmstrips, microforms, slides, maps, films, etc., in quantities appropria te to meet the instructional objectives of the curriculum.

1983 average cost per educational 15 -minute

$16 \mathrm{~mm}$ film

1983 average cost per filmstrip

$\$ 306.00$

average cost of nonprint up 300-500 per cent

in last 10 years

Equipment: microcomputers, projectors, record players, tape recorders, etc., in quantities appropriate to meet the instructional objectives of the curriculum.

1983 average cost of microcomputers $\$ 750.00-\$ 2,500.00$

1983 average cost of $16 \mathrm{~mm}$ film projector $\$ 750.00$

1983 average cost of cassette tape recorder $\$ 50.00-\$ 150.00$

\section{FACILITIES}

Space: accessible in scheduling and design to accommodate a minimum of 45 students or 15 per cent of the student enrollment areas: instruction, circulation, reference, conference, production, storage, office, reading, listening, and viewing guidance.

\section{BUDGET}

60 per cent or more of the instructional materials funds allocated by the state are needed to develop and maintain school library media collections.

In 1983-1984, instructional materials funds per ADM (average daily membership): 


\section{NCLA Minutes and Reports}

Grades K-3

Grades 4-6

Grades 7-12

Judie Davie

Chairman, NCASL

\section{Honorary and Life Membership in NCLA}

The 1984-1985 Honorary and Life Membership Committee requests your recommendations for persons you consider worthy to be honorary or life members in NCLA. Suggestions should be accompanied by a biographical sketch, including contributions to libraries or librarianship. These suggestions should be sent to the committee chairperson by January 31, 1985.

The NCLA by-laws provide for the Honorary and Life Membership Committee to seek suggestions from all members and to recommend names for these honors to the Executive Board at the Spring Workshop prior to the conference.

Criteria for selection are as follows:

1. Honorary memberships may be given to non-librarians in the state who have rendered important services to the library interests of North Carolina. Honorary memberships should be given at a time considered appropriate in relation to the contribution made.

2. Life memberships may be given to librarians who have served as members of the North Carolina Library Association and who have made noteworthy contributions to librarianship in the state. These memberships are limited to librarians who have retired.

3. Contributions of both groups should have been beyond the local level.

Please send your selections to:

Kathy Shropshire, chairperson

Honorary and Life Membership Committee Greensboro Public Library

P O Drawer X-4

Greensboro, NC 27402

\section{Join NCLA}

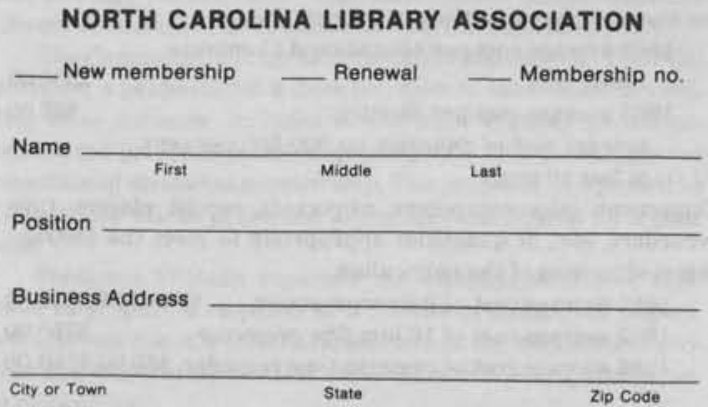

Mailing Address (if different from above)

Mail to:

Eunice Drum, Treasurer, NCLA, Division of State Library, 109 East Jones Street, Raleigh, NC 27611.

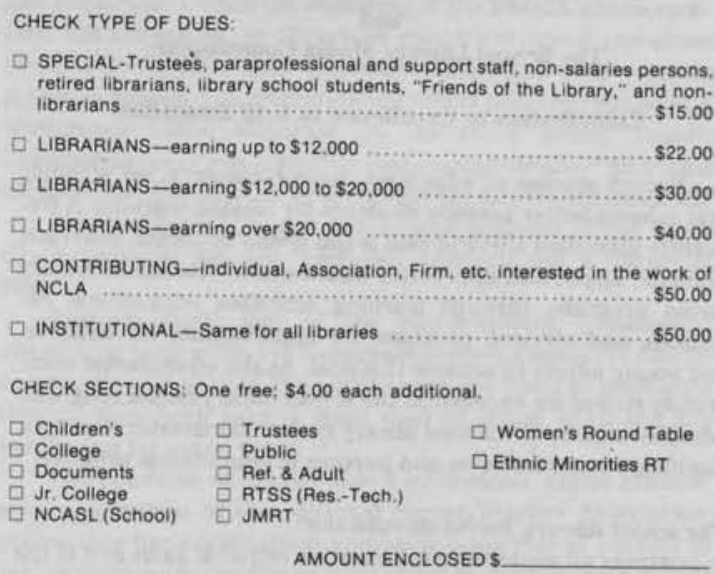

AMOUNT ENCLOSED $\$$ 


\title{
Treasurer's Report \\ January 1, 1983 - December 31, 1983
}

Exhibit A

(\$ 649.08)

Balance on Hand - January 1, 1983 - Checking Account

Receipts:

Dues and Receipts:

Association

Sections (Schedule 1)

Total Dues and Receipts

NORTH CAROLINA LIBRARIES (Schedule 1)

Reimbursed Expenses (THL)

Reimbursed Expenses (N.C. Educational Media)

Reimbursed Expenses (Exec. Board Meals)

Reimbursed Expenses (Ray Moore Fund)

Reimbursed Expenses (IFC Luncheon)

1983 Conference

RTSS/College \& Univ. Symposium Receipts

Dues Overpayment to be Refunded

Transfers from:

General Savings

RTSS Money Market Acct.

Scholarship Savings

Total Receipts

$\$ 25,044.50$

$\underline{10,632.74}$

tal Cash to Account For

Expenditures (Exhibit B)

Cash Balance, December 31, 1983

Does not include $\$ 30,813.25$ deposited in Cash Investment Accounts

Executive Office - Expenses:
Telephone
Postage
Computer Charges
Clerical Help
Photocopy
Audit and Preparation of 1982 Tax Forms
Mail Processing
P. O. Box Rent
Printing and Duplicating

Exhibit B

Cash Disbursements

President's Expenses

Other Officers' Expenses

ALA Representative Expenses

SEL.A Representative Expenses

NORTH CAROLINA LIBRARIES (Schedule 1)

TAR HEEL LIBRARIES

-1983 Conference

Transfers to:

General Savings

General Cash Investment Acct.

New Treasurer

Committee Expenses

Intellectual Freedom

Library Resources

Scholarship

Governmental Relations

Goals and Objectives

Honorary and Life Membership

Education for Librarianship

$6,500.00$

$1,100.00$

$3,000,00$

\author{
$\underline{10,600.00}$ \\ $35,677,24$ \\ $3,630.42$ \\ $1,783.44$ \\ 26.89 \\ 187.00 \\ 100.00 \\ 329.26 \\ $18,884.01^{\circ}$ \\ $4,438.03$ \\ 114.00
}

\$ 449.62

717.55

$1,235.62$

212,63

68.10

285.00

256.30

20.00

591.10

\$ $3,835,92$

766.38

123.54

$1,737.80$

189.86

$11,249.41$

$2,136.80$

$7,240.01$ •

$\$ 18,500.00$

$5,000.00$

500.00

$24,000.00$

$\$ 490.14$

200.00

200.00

527.72

36.16

151.34

268.00

$\begin{array}{r}1,873.36 \\ 15,284.60 \\ 200.00 \\ 50.00 \\ 151.00 \\ 219.62 \\ 86.76 \\ 8.10 \\ 205.92 \\ 3,000.00 \\ 1,000.00 \\ 100.00 \\ 103.96 \\ 47.61 \\ \hline \$ 73,610.65 \\ \hline\end{array}$

Sections Expenses (Schedule 1)

Freedom to Read Foundation 1983 \& 1984 Membership

ALA 1984 Membership Dues

Refund of Dues

Spring Workshop

Bulk Mail Account Deposits (less reimbursements)

Labels for UNC-CH Librarians' Association

Executive Board Meals

Scholarships (3)

Loqns (5)

Ray Moore Awards

Expenses to be reimbursed

Other Expenses

$\$ 73,610,65$

Total Disbursements (To Exhibit A)

-Does not include \$18,956.66 paid from Cash Investment Account. 


\section{3-85}

\section{President}

LELAND M. PARK

Davidson College Library

Davidson, NC 28036

(704) 892-2000 Ext. 331

First Vice-President/

President-Elect

PAULINE F. MYRICK

Moore County Schools

Box 307

Carthage, NC 28327

(919) 947-2976

Second Vice-President

M. JANE WILLIAMS

Division of State Library

109 East Jones Street

Raleigh, NC 27611

(919) 733-2570

\section{Secretary}

ROBERTA S. WILLIAMS

Transylvania County Library

105 South Broad Street

Brevard, NC 28712

(704) 884-3151

\section{Treasurer}

EUNICE P. DRUM

Box 40034

Raleigh, NC 27604

(919) $733-4488$

Director

SHIRLEY B. McLAUGHLIN

Asheville-Buncombe Technical College

340 Victoria Road

Asheville, NC 28801

(704) 254-1921 Ext. 300

\section{Director}

JERRY A. THRASHER

Cumberland County Public Library

Box 1720

Fayetteville, NC 28302

(919) 483-1580

Past President

MERTYS W. BELL

Guilford Technical Community College

Box 309

Jamestown, NC 27282

(919) 292-1101 Ext. 2295

\section{ALA Representative}

\section{EMILY BOYCE}

Department of Library Science East Carolina University Greenville, NC 27834

(919) 757-6621

\author{
SELA Representative \\ REBECCA S. BALLENTINE \\ Institute of Government \\ UNC-Chapel Hill \\ Chapel Hill, NC 27514 \\ (919) 966-4130
}

\author{
Editor, North Carolina Libraries \\ ROBERT BURGIN \\ Forsyth County Public Library \\ 660 West 5 th Street \\ Winston-Salem, NC 27101 \\ (919) 727-2556
}

\section{SECTION/ROUNDTABLE CHAIRS}

\section{Children's Services \\ KAREN M. PERRY}

Archdale-Trinity Middle School Box 232

Trinity, NC 27370

(919) 431-6714

College and University

ROBERT N. BLAND

Ramsey Library

UNC-Asheville, NC 28814

(704) 258-6543

\section{Documents}

EMILY CORRELL

Public Library of Charlotte and Mecklenburg County

310 North Tryon Street

Charlotte, NC 28202

(704) $374-2540$

\section{Junior Colleges \\ ANDREA P. BROWN}

Kenan Library

St. Mary's College

900 Hillsborough Street

Raleigh, NC 27603-1689

(919) 828-2521 Ext. 313

Junior Members Roundtable

VIVIAN W. BEECH

New Hanover County Public Library

201 Chestnut Street

Wilmington, NC 28403

(919) 763-3303

\section{N.C. Association of School}

Librarians

JUDIE DAVIE

Department of Library Science/

Educational Technology

UNC-Greensboro

Greensboro, NC 27412

(919) 379-5100 Ext. 63
Public Library

JUDITH K. SUTTON

Public Library of Charlotte and Mecklenburg County

310 North Tryon Street Charlotte, NC 28202

(704) 374-2660

\section{Reference and Adult Services}

LARRY BARR

Department of Library and Media Studies

Appalachian State University

Boone, NC 28608

(704) 262-2243

Resources and Technical Services BENJAMIN F. SPELLER, JR.

School of Library Science

North Carolina Central University Durham, NC 27707

(919) 683-6485

Roundtable for Ethnic Minority

Concerns

MARY P. WILLIAMS

J. Y. Joyner Library

East Carolina University

Greenville, NC 27834

(919) 757-6691

Roundtable on the Status of Women in Librarianship

PATSY J. HANSEL

Cumberland County Public Library

Box 1720

Fayetteville, NC 28302

(919) 483-8600

\section{Trustees}

DOROTHY R. BURNLEY

508 Ashe Street

High Point, NC 27260

(919) $733-4838$

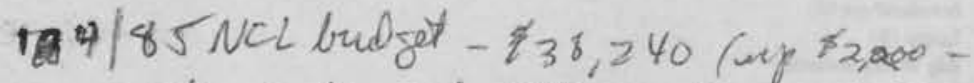
pinting costs my by $7 \%$; werhead mo elinge)

ment bol migh $-12 / 5$, at Duke 1000 


\title{
Put the power of National Geographic into your library....
}

You can develop a more powerful science curriculum with these brand-new sound-and-color filmstrip sets.

The Universe: Frontiers of Discovery Sertes Part t Thie Solar System

Grades 712

No. 04772 Five filmstrips, $\$ 129.50$

Part Il: Deep Space and the Mysteries of the Cosmos

Grades 7.12

No. 04788 Three filmstrips. $\$ 799,95$

Save $10 \%$ on a single purchase order of the

two part Universe series

No. 04798 . W . $\$ 188.50$

Learning About Chemicals

Grades 69

No. 04702 Two filmstrips. $\$ 59.95$

An Introduction to Chemistry

Grades 7.12

No, 04709 Three filmstrips: $\$ 7995$

Purchase directly from National

Geographic Educational Services,

Washington. D.C. 20036

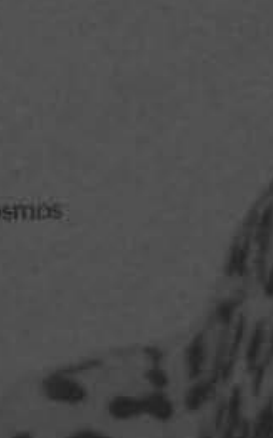

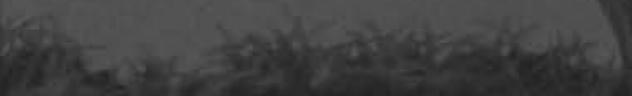

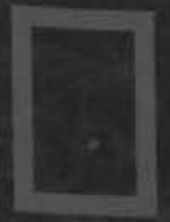

NATIONAL

GDOGRAPHIC Educational Services

\author{
Call Toll pree \\ $800-368-2728$
}



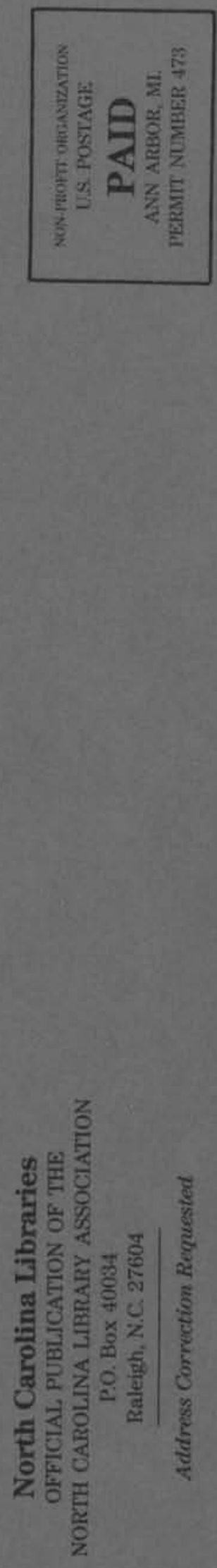